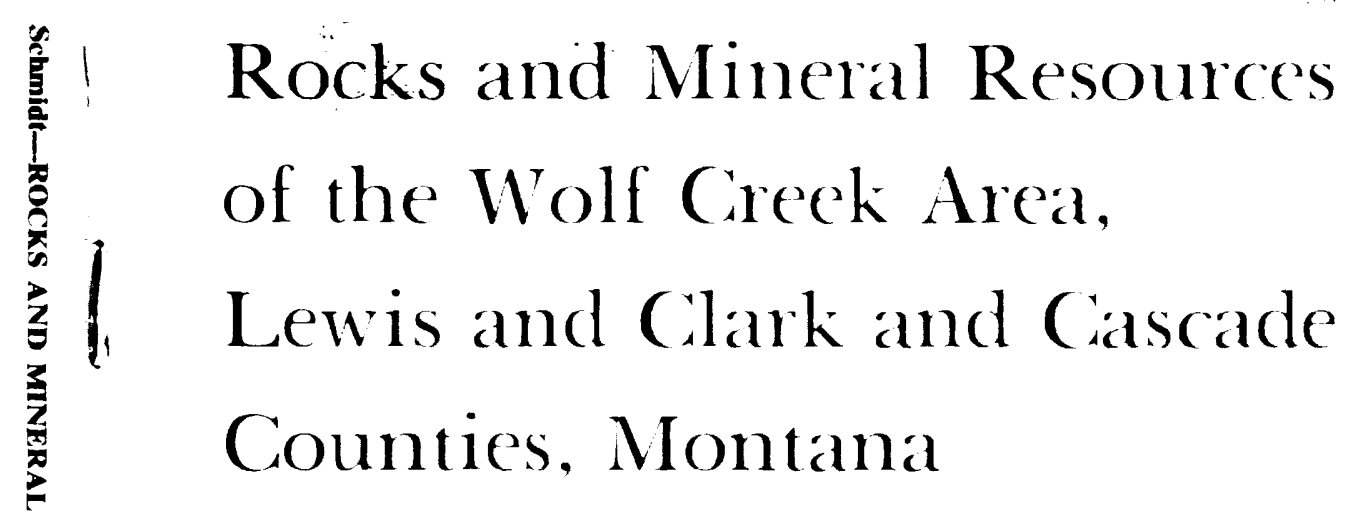

GEOLOGICAL SURVEY B I I. ETIN $14+1$
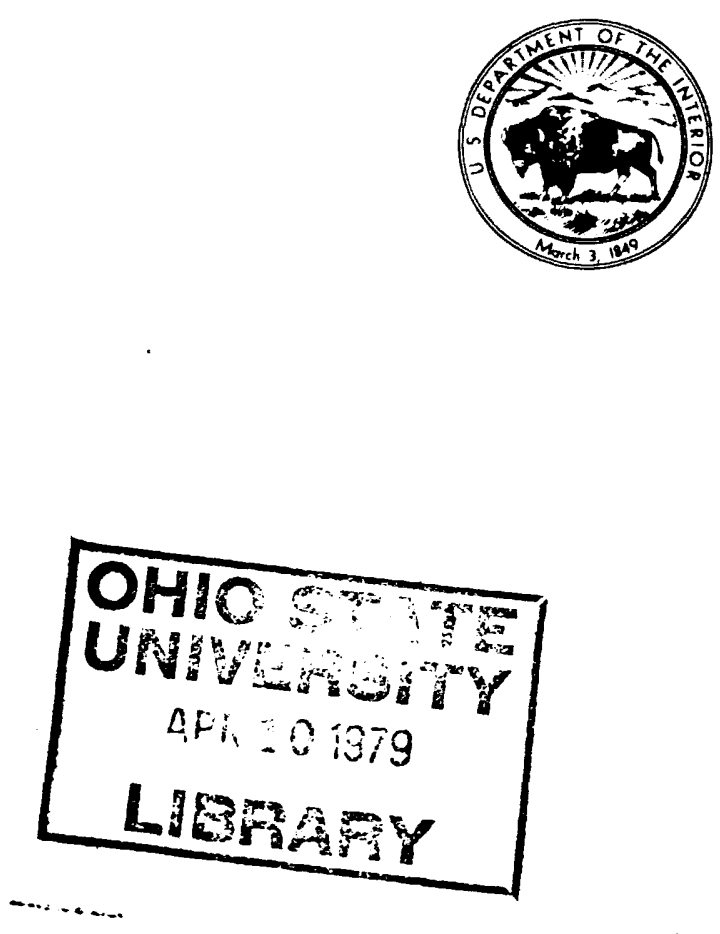
1

1 


\section{Rocks and Mineral Resources}

of the Wolf Creek Area,

Lewis and Clark and Cascade

Counties, Montana

By ROBERT GEORGE SCHMIDT

G E O L O G I C A L S U R V E Y B U L L E T I N 1441

$A$ descriptive report on an area in the disturbed belt along the eastern front of the northern Rocky Mountains

in western Montana

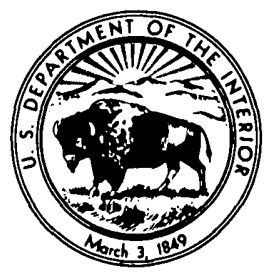




\section{UNITED STATES DEPARTMENT OF THE INTERIOR}

CECIL D. ANDRUS, Secretary

GEOLOGICAL SURVEY

H. William Menard Director

\section{Library of Congress Cataloging in Publication Data}

Schmidt, Robert George.

Rocks and mineral resources of the Wolf Creek area, Lewis and Clark and Cascade Counties, Montana.

(Geological Survey bulletin; 1441)

Bibliography: p.

Includes index.

Supt. of Docs. no.: I 19.3:1441

1. Geology-Montana-Lewis and Clark Co. 2. Geology-Montana-Cascade County. 3. Mines and mineral resources-Montana-Lewis and Clark Co. 4. Mines and mineral resources-Montana-Cascade County. I. Title. II. Series: United States. Geological Survey. Bulletin; 1441. QE75.B9 no. 1441 [QE134.L43] 557.3'08s [557.86'61] 77-608050

For sale by Superintendent of Documents, U.S. Government Printing Office Washington, D.C. 20402

Stock Number 024-001-031205 


\section{CONTENTS}

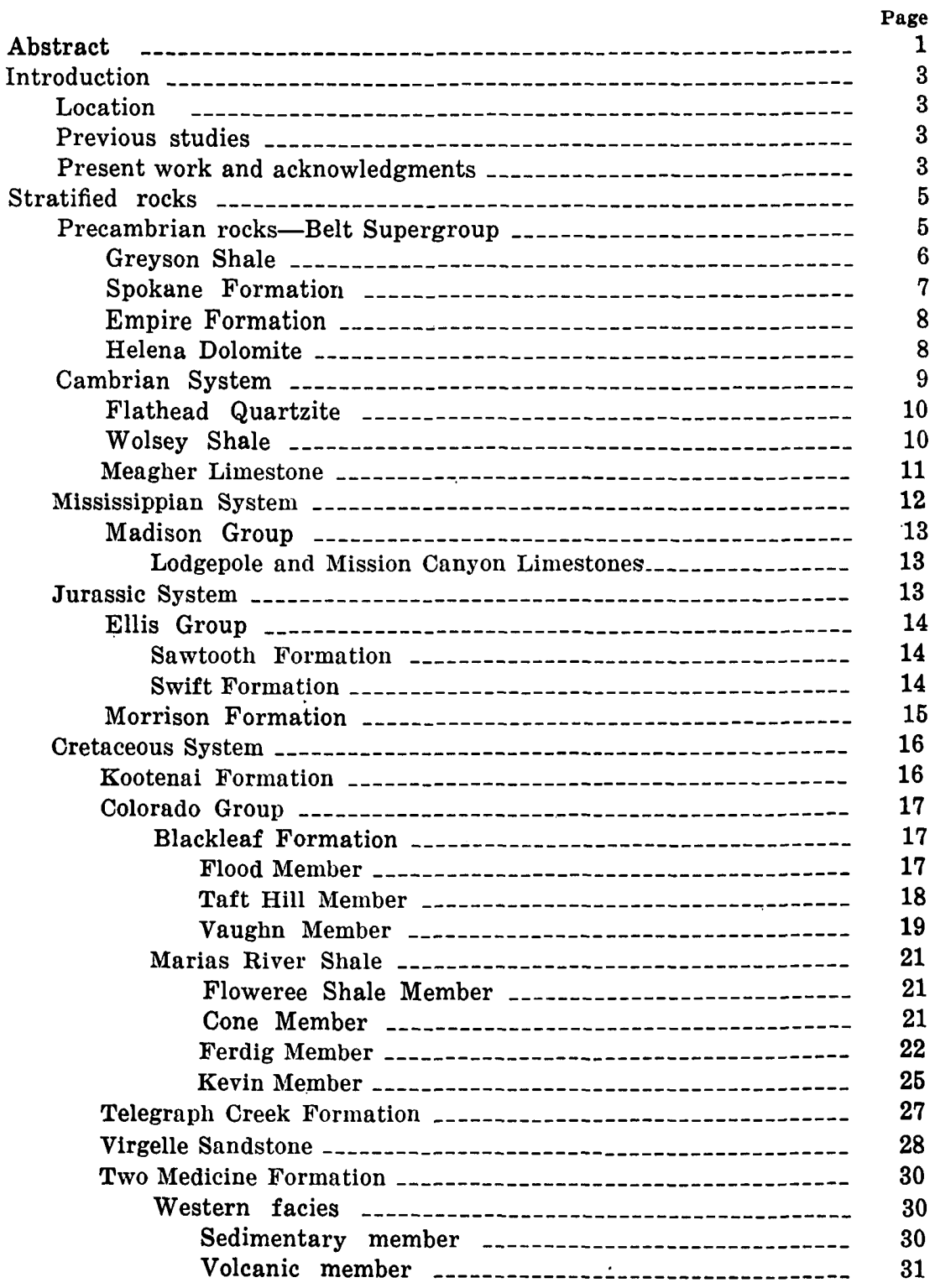


Stratified rocks-Continued

Cretaceous System-Continued

Two Medicine Formation-Continued

Eastern facies

St. Mary River Formation

Cretaceous and Tertiary Systems _-_._- 47

Willow Creek Formation

Adel Mountain Volcanics of Lyons (1944)

Older colluvial deposits

Quaternary System _._. 54

Terrace gravel _. 54

Glacial lake deposits _. 55

Colluvial deposits

Landslide deposits _. 56

Alluvium _._- 56

Intrusive rocks _-_

Precambrian _.- 57

Gabbro - 57

Cretaceous _- 57

Latite _. 57

Trachyte _... 59

Probable Cretaceous _- 59

Diorite _. 59

Rhyodacite porphyry 59

Quartz monzonite porphyry 60

Cretaceous or Tertiary _.. 60

Rhyolite _-_ 60

Probable Tertiary _- 61

Analcime' gabbro _. 61

Trachybasalt

Quartz monzonite porphyry 61

Tertiary

Hornblende monzonite 62

Mineral resources _._. 63

Metallic-mineral deposits _. 63

Veins bearing copper, silver, and gold _._. 63

Rosetta mine 64

Gladstone Creek _. 65

Middle Fork of Little Creek 65

Divide between Little Creek and Wolf Creek._._._. 65

Lanigan Mountain _: 66

Willis Creek _an 66

Little Creek and Sheep Creek _. 67

Sedimentary deposits of titaniferous iron ore._._. 68

Industrial-mineral resources _. 69

Gravel and sand 69

Construction stone 70

Welded tuff _. 70

Latite and trachyte

Trachybasalt _._. 72

Quartzitic sandstone and quartzite _... 73 
Mineral resources-Continued

Page

Industrial-mineral resources-Continued

Argillite and siltite -

Limestone -

Clay and clay shale

Bentonite -.-.-_-

Silica --

Coal _- 81

References cited --.-- 83

Index -...- 87

\section{ILLUSTRATIONS}

Plate 1. Geologic map of the Wolf Creek area, Lewis and Clark

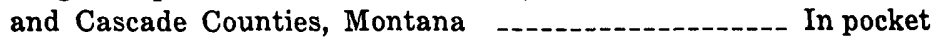

2. Chart showing Late Cretaceous age relations and probable correlation of Upper Cretaceous rocks of the Wolf Creek area with rocks of other areas in Montana and Wyoming

In pocket

FIGURE 1. Map showing location of the Wolf Creek area and U.S.

Page

Geological Survey quadrangles

\section{TABLES}

TABLE 1. Chemical analyses of rocks from the volcanic member of the western facies of the Two Medicine Formation

2. Chemical analyses of rocks from the Adel Mountain Volcanics of Lyons (1944)

3. Chemical analyses of dikes and sills in the Wolf Creek area, Montana 


\title{
ROCKS AND MINERAL RESOURCES OF THE WOLF CREEK AREA, LEWIS AND CLARK AND CASCADE COUNTIES, MONTANA
}

\author{
By Robert George SchmidT
}

\begin{abstract}
The Wolf Creek area covers about 200 square miles $\left(518 \mathrm{~km}^{2}\right)$ along the eastern front of the northern Rocky Mountains in Lewis and Clark and Cascade Counties in western Montana.

Stratified rocks in the area include a wide variety of sedimentary and volcanic rocks of Precambrian, Cambrian, Mississippian, Jurassic, Cretaceous, Tertiary, and Quaternary age. The maximum aggregate thickness of these rocks is about 24,000 feet $(7,316 \mathrm{~m})$.

Precambrian strata are represented by the Greyson Shale, Spokane Formation, Empire Formation, and Helena Dolomite of Precambrian Y age. These formations, of marine origin, belong to the lower part of the Belt Supergroup. The Greyson Shale, Spokane Formation, and Empire Formation consist chiefly of thinly laminated argillite, siltite, quartzite, and limestone; the Helena Dolomite consists mainly of thinly laminated dolomite, dolomitic limestone, and argillaceous limestone. The Belt strata have a maximum aggregate thickness of about 9,500 feet $(2,896 \mathrm{~m})$.

The Cambrian System is represented by the marine Flathead Quartzite, Wolsey Shale, and Meagher Limestone of Middle Cambrian age. The Cambrian rocks have a maximum aggregate thickness of about 800 feet $(244 \mathrm{~m})$.

Rocks of the Mississippian System are represented only by small faulttransported blocks of Lodgepole Limestone and Mission Canyon Limetone of the Madison Group of Early and Late Mississippian age.

The Jurassic System is represented by the Sawtooth Formation of Middle Jurassic age and the Swift and Morrison Formations of Late Jurassic age. The Sawtooth Formation consists chiefly of marine clastic limestone and calcareous shale. The Swift Formation consists mainly of marine shale and sandstone. The Morrison Formation, of continental origin, is composed of freshwater limestone, mudstone, and sandstone. The Jurassic rocks have a maximum aggregate thickness of about 470 feet $(143 \mathrm{~m})$.

Rocks assigned to the Cretaceous System include the Kootenai and Blackleaf Formations of Early Cretaceous age and the Marias River Shale, Telegraph Creek Formation, Virgelle Sandstone, Two Medicine Formation, and St. Mary River Formation of Late Cretaceous age. The Cretaceous rocks have a maximum aggregate thickness of about 8,600 feet $(2,621 \mathrm{~m})$.

The Kootenai Formation, of continental origin, is composed largely of sandstone and mudstone. The lower part of the Blackleaf Formation (Flood
\end{abstract}


and Taft Hill Members) consists mainly of marine sandstone, siltstone, and shale; the upper part (Vaughn Member) is of continental origin and is composed largely of tuffaceous sandstone, siltstone, mudstone, and bentonite. The lower part of the Marias River Shale (Floweree Shale and Cone Members) is predominantly dark marine shale, the middle part (Ferdig Member) contains significant amounts of marine siltstone and sandstone, and the upper part (Kevin Member) is mainly dark fossiliferous marine shale. The Telegraph Creek Formation consists of alternating beds of marine shale and sandstone. The Virgelle Sandstone is chiefly a massive thickbedded feldspathic marine sandstone. The Two Medicine Formation consists of two spatially separated rock sequences that differ greatly from one another in overall lithology. The western facies, largely of continental origin, is divided into a lower sedimentary member composed mainly of sandstone, mudstone, and carbonaceous shale and an upper volcanic member composed of clastic volcanic rocks, latitic and trachytic lava flows, and ashflow tuff. The eastern facies, also largely of continental origin, is made up of sandstone, mudstone, carbonaceous shale, bentonite, and clastic volcanic rocks. The St. Mary River Formation is formed largely of sandstone, siltstone, and mudstone of continental and brackish-water origin.

Strata assigned to the Cretaceous and Tertiary Systems include the Willow Creek Formation of Late Cretaceous and Early Paleocene(?) age, the Adel Mountain Volcanics of Lyons (1944) of probable Paleocene age, and older colluvial deposits of probable Pliocene age, all of continental origin. The maximum aggregate thickness of these rocks is about 4,320 feet $(1,317 \mathrm{~m})$. The Willow Creek Formation consists largely of variegated tuffaceous sandstone, siltstone, mudstone, and volcanic-pebble conglomerate. The Adel Mountain Volcanics of Lyons (1944) is composed mainly of trachybasaltic and trachyandesitic lava flows and clastic volcanic rocks. The older colluvial deposits consist of coarse unconsolidated rock debris of local origin.

The Quaternary System is represented by terrace gravel and glacial-lake deposits of Pleistocene age, colluvial and landslide deposits of Pleistocene and Holocene age, and alluvium of Holocene age. These deposits, widely distributed throughout the area, have a maximum aggregate thickness of about 275 feet $(84 \mathrm{~m})$.

Intrusive rocks in the area include gabbro of probable Precambrian age; latite and trachyte of Cretaceous age; diorite, rhyodacite porphyry, and quartz monzonite porphyry of probable Cretaceous age; rhyolite of Cretaceous or Tertiary age; analcime gabbro, trachybasalt, and quartz monzonite porphyry of probable Tertiary age; and hornblende monzonite of Tertiary age. The intrusive rocks are found mostly in the form of dikes and sills.

The area contains insignificant metallic mineral deposits and more promising industrial mineral resources. The metallic mineral deposits consist of small veins bearing copper, silver, and gold, and sedimentary deposits of titaniferous iron ore. The industrial mineral resources include gravel and sand, several types of construction stone, clay and clay shale, bentonite, silica, and coal. Construction stone, including both dimension stone and crushed and broken stone, is the most abundant mineral resource. The rocks that may be utilized as construction stone include welded tuff, latite and trachyte, trachybasalt, quartzitic sandstone and quartzite, argillite and siltite, and limestone. 


\section{INTRODUCTION}

\section{LOCATION}

The Wolf Creek area, as here defined, covers about 200 square miles $\left(518 \mathrm{~km}^{2}\right)$ along the eastern front of the northern Rocky Mountains in western Montana. The area is bounded by long $112^{\circ} 00^{\prime}$ $\mathrm{W}$. and $112^{\circ} 15^{\prime} \mathrm{W}$. and by lat $47^{\circ} 00^{\prime} \mathrm{N}$. and $47^{\circ} 15^{\prime} \mathrm{N}$. (fig. 1 ). About 8 square miles $\left(22 \mathrm{~km}^{2}\right)$ in the northeastern part of the area is in Cascade County; the remainder is in Lewis and Clark County. The town of Wolf Creek, population about 100, is the only settlement. Helena, the State capital, is 28 miles $(45 \mathrm{~km})$ south, and Great Falls is 40 miles $(64 \mathrm{~km})$ northeast. The Wolf Creek area encompasses four 71/2-minute topographic quadrangle maps of the U.S. Geological Survey-the Wolf Creek, Coburn Mountain, Comb Rock, and Roberts Mountain quadrangles. (See fig. 1.)

\section{PREVIOUS STUDIES}

Earlier geologic studies have touched upon this region. Alden $(1932$, p. 17,48$)$ noted Pleistocene terrace gravel along the Middle and South Forks of the Dearborn River and along Little Prickly Pear Creek. Pardee and Schrader (1933, p. 108-114) described small lode deposits of copper, silver, and gold in the Wolf Creek district of the greater Helena mining region and noted several salient features of the geology. Lyons (1944) described the igneous rocks of the northern Big Belt Range and made general observations on the stratigraphy and structure. He included most of the eastern part of the Wolf Creek area in his study. Cobban (1945, p. 1296-1297) described a section of the Sawtooth and Swift Formations on the north side of the Missouri River in the adjacent Craig quadrangle. Glassy welded tuff from the adjacent Sheep Creek quadrangle was described by Barksdale (1951), and a chemical analysis of this rock was later given by Knopf $(1957$, p. 87). The Two Medicine, Horsethief, St. Mary River, and Willow Creek Formations north of the Wolf Creek area have been discussed by Viele and Harris (1965). Most recently, Robinson and Marvin (1967, p. 606-607, table 1) have reported on the composition and radiometric age of glassy welded tuff from the area.

\section{PRESENT WORK AND ACKNOWLEDGMENTS}

Fieldwork was carried out in the area from 1959 to 1966, and preliminary uncolored geologic maps of the Wolf Creek, Coburn Mountain, Comb Rock, and Roberts Mountain quadrangles were 


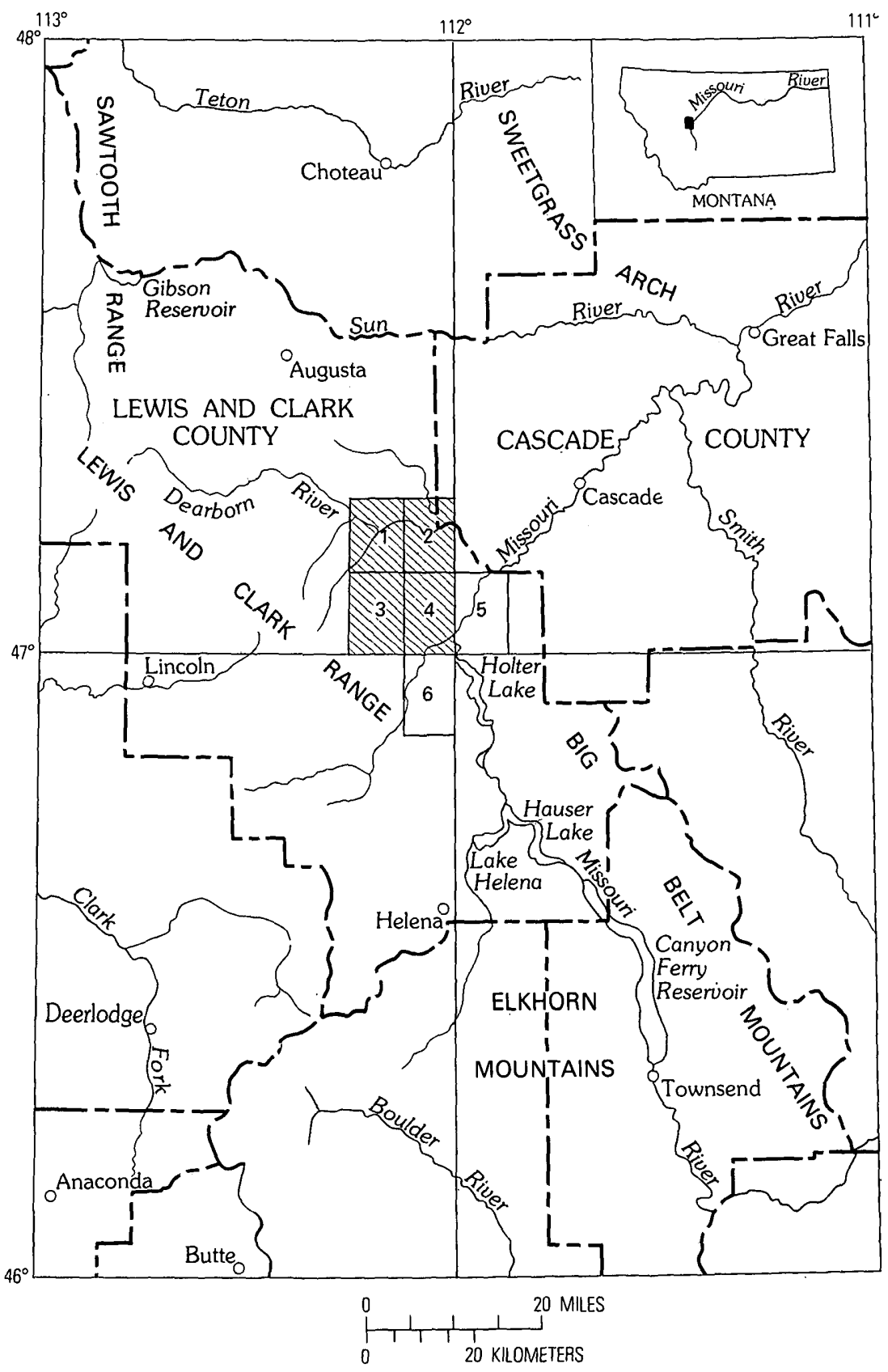

Figure 1.-Map showing location of the Wolf Creek area (shaded) and location of U.S. Geological Survey quadrangles mentioned in this report. 1, Comb Rock quadrangle; 2, Coburn Mountain quadrangle; 3 , Roberts Mountain quadrangle; 4, Wolf Creek quadrangle; 5, Craig quadrangle; 6 , Sheep Creek quadrangle. 
published at a scale of $1: 24,000$ (Schmidt 1963, 1966; Schmidt, Swanson, and Zubovic, 1964; Schmidt and Strong, 1968). Final multicolor maps have now been published, also at a scale of 1:24,000 (Schmidt, 1972a, b, c; Schmidt and Strong, 1972). The geology of the four quadrangles is somewhat generalized at a scale of $1: 48,000$ in plate 1 of this report. In the report, new information is provided on the stratigraphy, paleontology, and petrography of the rocks and on the mineral resources of the area. The rock descriptions, which constitute the bulk of the report, are rather technical and are intended primarily for geologists; the section on mineral resources, which should be read in conjunction with plate 1 , is more suitable for the general public.

Herbert R. Shaw, Ceylon P. Strong, Jr., Donald A. Swanson, and Peter Zubovic assisted ably with the fieldwork at various times. Charles E. Erdmann and Andrew F. Bateman, Jr., of the Great Falls, Mont., office of the U.S. Geological Survey, provided office space, storage facilities, and supplies that aided the work in many ways. Many other colleagues on the staff of the U.S. Geological Survey have contributed ideas and information that have been helpful to the study. William A. Cobban, Montis R. Klepper, and the late William T. Pecora made reconnaissance geologic studies in the Wolf Creek area prior to 1959 and introduced the writer to the geology of this part of Montana. William A. Cobban visited the field party in 1959,1960, and 1962, and assisted greatly by skillful collecting of fossils and by providing information on the stratigraphy of the Cretaceous rocks. Discussions in the field with James R. Gill, Montis R. Klepper, Melville R. Mudge, W. Bradley Myers, G. D. Robinson, Harry W. Smedes, and Robert L. Smith aided in solving several lithologic and stratigraphic problems. Fossils collected during the course of the fieldwork were identified by William A. Cobban, J. Thomas Dutro, Jr., Allison R. Palmer, William J. Sando, and Norman F. Sohl.

\section{STRATIFIED ROCKS}

The stratified rocks in the Wolf Creek area include a wide variety of sedimentary and volcanic rocks of Precambrian, Cambrian, Mississippian, Jurassic, Cretaceous, Tertiary, and Quaternary age. The maximum aggregate thickness of these rocks is about 24,000 feet $(7,316 \mathrm{~m})$.

\section{PRECAMBRIAN ROCKS-BELT SUPERGROUP}

Precambian strata are represented by the Greyson Shale, Spokane Formation, Empire Formation, and Helena Dolomite of 
Precambrian $\mathrm{Y}$ age. These formations, of marine origin, belong to the lower part of the Belt Supergroup. The Belt strata have a maximum aggregate thickness of about 9,500 feet $(2,896 \mathrm{~m})$.

\section{GREYSON SHALE}

The lower boundary of the Greyson Shale is marked by the Eldorado and Wolf Creek thrust faults, and only the upper part of the formation is present. Along the front of the Lewis and Clark Range, above the Eldorado thrust fault, the maximum exposed thickness of the Greyson is about 2,000 feet $(610 \mathrm{~m})$. Above the Wolf Creek thrust fault, the maximum exposed thickness of the formation is about 2,500 feet $(762 \mathrm{~m})$.

The Greyson consists mainly of thin beds of gray and green argillite ${ }^{1}$ and siltite, ${ }^{1}$ light-gray quartzite, ${ }^{1}$ and gray algal limestone. The rocks weather to shades of green, tan, and brown. The argillite and the siltite are thinly and evenly bedded; in places they have a well-developed fissility and resemble slate. The bedding surfaces of these rocks commonly have ripple marks and mudcrack casts, and some beds contain cube-shaped casts of salt crystals. Beds of quartzite and limestone are scarce. They are as much as 2 feet $(60 \mathrm{~cm})$ thick and are most abundant in the upper part of the formation. Some of the quartzite is finely crossbedded. At the top of the Greyson is a transitional sequence of interbedded gray, green, and red argillite and siltite and gray to white quartzite 200 to 600 feet ( 60 to $183 \mathrm{~m}$ ) thick. Beds of red argillite and siltite are more abundant upward in this transition zone; the boundary between the Greyson Shale and the overlying Spokane Formation is arbitrarily placed where the rocks are predominantly red.

The gray and green argillite and siltite are composed primarily of exceedingly fine grains of quartz, alkali feldspar, muscovite (sericite), and chlorite. Some of these rocks also contain a minor amount of interstitial carbonate, either calcite or dolomite. The argillite generally contains more muscovite and chlorite and correspondingly less quartz and feldspar than does the siltite. The red argillite and siltite in the transition zone at the top of the Greyson contain scattered flecks of hematite. The quartzite is very fine grained, mostly impure and argillic, and differs from the siltite mainly in having a higher content of quartz. The limestone has either a thin wavy laminated structure or a concentrically

\footnotetext{
1 The nomenclature of these rocks conforms with that of Harrison and Campbell (1963, p. 1416) In which argillite refers to the low-grade metamorphic equivalent of claystone or silty claystone, siltite refers to the low-grade equivalent of slltstone, and quartzlte refers to the low-grade equivalent of sandstone.
} 
laminated elliptical structure produced by algal growth. It generally contains some detrital quartz and feldspar in addition to carbonate.

\section{SPOKANE FORMATION}

The Spokane Formation attains a maximum thickness of about 2,500 feet $(762 \mathrm{~m})$ along the front of the Lewis and Clark Range, where it is mapped with the Empire Formation as an undivided unit. South and west of the Wolf Creek thrust fault, the formation is about 3,000 feet $(914 \mathrm{~m})$ thick. About 1,000 feet $(305 \mathrm{~m})$ of Spokane strata crop out above the Lyons thrust fault in the southwest corner of the area.

Thin beds of red and purplish-red argillite and siltite form the bulk of the formation. A few thin beds of green argillite and siltite, tan-weathered quartzite, and brown-weathered dolomitic limestone are interbedded with the red rocks. The argillite and siltite are evenly and thinly bedded like those in the Greyson Shale, and their bedding surfaces commonly show ripple marks and mud-crack casts. The beds of quartzite are as much as 3 feet $(1 \mathrm{~m})$ thick and are most abundant near the middle of the Spokane. Commonly they contain thin partings of red argillite; some of these partings grade laterally into thin beds of mud-flake breccia that consists of small flat pebbles and chips of red argillite in a gray quartzitic matrix. Some of the quartzite is finely crossbedded. Beds of dolomitic limestone are few, are as much as 2 feet $(60 \mathrm{~cm})$ thick, and are found in the upper half of the formation. They are distinctly granular and sandy, slightly pitted, and show a delicate etched lamination produced by differential weathering. At the top of the Spokane is a transitional sequence of interbedded red and green argillite and siltite 100 to 200 feet $(30$ to $60 \mathrm{~m})$ thick. The green beds increase in abundance upward in this transition zone, and the boundary between the Spokane and the overlying Empire Formation is arbitrarily placed where the rocks are predominantly green.

The red argillite and siltite of the Spokane are composed primarily of exceedingly fine grains of quartz, alkali feldspar, muscovite (sericite), chlorite, and hematite. The green argillite and siltite contain much more chlorite than the red rocks and are devoid of hematite. The bedding surfaces of siltite are commonly coated with flakes of muscovite that glisten in the sun. The quartzite is fine grained and ranges in composition from impure varieties containing considerable alkali feldspar, chlorite, and muscovite to fairly pure types composed mainly of quartz grains. The 
dolomitic limestone contains small amounts of quartz, feldspar, muscovite, and chlorite.

\section{EMPIRE FORMATION}

Along the front of the Lewis and Clark Range, where it is mapped with the Spokane Formation, the Empire Formation is unconformably overlain by the Flathead Quartzite of Middle Cambrian age, and the top is not exposed. In this occurrence, the maximum thickness of the Empire is about 800 feet $(244 \mathrm{~m})$. South and west of the Wolf Creek thrust fault, the formation is about 1,000 feet $(305 \mathrm{~m})$ thick.

The Empire Formation consists mainly of thin beds of green argillite and siltite. A few thin beds of red argillite and siltite and pale-green to white quartzite are present in the lower part and thin beds of gray argillaceous limestone in the upper part. The argillite and siltite are characteristically very thinly laminated, more so than similar rocks in the Greyson Shale and Spokane Formation. Ripple marks and mud-crack casts are present on the bedding surfaces of the argillite and siltite, and the quartzite is locally crossbedded, but these structures are not as common as in the Greyson and Spokane. At the top of the Empire is a transitional sequence of interbedded green argillite and siltite and gray to bluish-gray, tan-weathered dolomitic limestone 50 to 100 feet $(15$ to $30 \mathrm{~m})$ thick. A few thin beds of red argillite also are present in this sequence. The boundary between the Empire Formation and the overlying Helena Dolomite is arbitrarily placed where the beds of dolomitic limestone are predominant.

The green argillite and siltite of the Empire are composed of exceedingly fine grains of quartz, muscovite (sericite), chlorite, and alkali feldspar. The red argillite and siltite in the upper and lower parts of the formation contain small flecks of hematite. Much of the argillite and siltite is calcareous, especially near the top of the formation, and some of the rock contains enough carbonate to be classified as argillaceous limestone. The carbonate, either calcite or dolomite, forms discrete crystals, clusters or clots of discrete crystals, and cement. The quartzite, composed largely of small quartz grains, commonly contains some alkali feldspar, muscovite, and chlorite.

\section{HELENA DOLOMITE}

The upper boundary of the Helena Dolomite is marked by the Lyons thrust fault, and an unknown thickness at the top of the 
formation is missing. The maximum exposed thickness is about 3,000 feet $(914 \mathrm{~m})$.

The Helena consists largely of gray and bluish-gray fine-grained thinly laminated dolomite, dolomitic limestone, dolomitic mudstone, and argillaceous limestone that weather tan and light orange. The rocks are in beds a fraction of an inch (a few millimeters) to a foot $(30 \mathrm{~cm})$ or two $(60 \mathrm{~cm})$ thick. Some are finely crossbedded, and ripple marks and mud-crack casts are locally present on bedding surfaces. The weathered surfaces of some outcrops of dolomitic limestone are deeply etched in the rough crinkled pattern known as molar-tooth structure. Generally the rocks contain small amounts of detrital quartz, feldspar, muscovite, chlorite, and dark carbonaceous (?) material in addition to carbonate. In places, thin beds of gray, green, red, and pink argillite and siltite are interlayered with the carbonatic rocks. They are most abundant in the upper part of the formation.

Biostromes of massive dark-gray dolomitic limestone composed of stromatolites occur throughout the Helena. The stromatolites probably belong to the genus Collenia, which has been described in equivalent rocks in Glacier National Park by Rezak (1957, p. 133134). The biostromes weather light bluish gray, are as much as 3 feet $(1 \mathrm{~m})$ thick, are of wide lateral extent, and are composed of closely packed domesshaped colonies of thinly laminated stromatolites several inches (several centimeters) to a foot $(30 \mathrm{~cm})$ or more across and as much as 3 feet $(1 \mathrm{~m})$ high. On the weathered surface, the stromatolite laminae are differentially etched and stand out in bold relief. Some of the stromatolite layers are overlain by thin beds of edgewise conglomerate made up of flat pebbles of laminated stromatolitic limestone inclined at a steep angle to the bedding and surrounded by an oolitic matrix. Some edgewise conglomerate grades upward into thin beds of oolite. At several levels in the Helena, the stromatolite biostromes are closely spaced, forming zones of massive dolomitic limestone 10 to 20 feet ( 3 to $6 \mathrm{~m}$ ) thick. These zones form prominent benches and ledges on the hillslopes. The thickest stromatolite zone is about 1,600 feet $(488 \mathrm{~m})$ above the base of the formation.

\section{CAMBRIAN SYSTEM}

Strata of Cambrian age include the Flathead Quartzite, Wolsey Shale, and Meagher Limestone of Middle Cambrian age. These formations, of marine origin, belong to the lower part of the Cam- 
brian succession of Montana. Their aggregate thickness is about 800 feet $(244 \mathrm{~m})$.

\section{FLATHEAD QUARTZITE}

The Flathead Quartzite rests unconformably on the Empire and Spokane Formations of the Belt Supergroup, truncating the contact between the Spokane and Empire at a low angle on the south flank of Roberts Mountain. The thickness of the Flathead ranges from 90 to 120 feet (27 to $37 \mathrm{~m}$ ).

The formation consists mainly of thick beds of medium- to coarse-grained orthoquartzite. Pebble and granule conglomerate zones are present locally and are most common near the base. In places, thin beds of greenish-gray 'sandy micaceous shale are interlayered with the quartzite beds. The quartzite is mostly pale gray, white, and light reddish gray and weathers tan to brown. Locally, the rock is streaked by conspicuous narrow redpurple bands. Many of the quartzite layers are crossbedded, and very commonly the individual cross laminae are alternately light and dark red, which enhances this structure. Some of the quartzite layers show graded bedding, and ripple marks are present on a few bedding surfaces. At the top of the Flathead is a transitional sequence of interbedded greenish-gray shale and pale-gray quartzite 5 to 10 feet $(1.5$ to $3 \mathrm{~m})$ thick. The boundary with the overlying Wolsey Shale is arbitrarily placed at the base of this transitional zone or, where the shales do not crop out, at the base of the dip slope on the uppermost quartzite bed.

The quartzite is composed almost entirely of quartz grains that range from silt size to small pebbles as much as half an inch (1 $\mathrm{cm}$ ) across. These grains have overgrowths of quartz that firmly cement the rock. Minor constituents include small grains of feldspar, muscovite, magnetite, and zircon. Small flakes of hematite are also present, and thin films of a red opaque material, which is probably hematite, commonly coat quartz grains and give the rock its reddish cast.

\section{WOLSEY SHALE}

The Wolsey Shale lies conformably on the Flathead Quartzite and has a maximum thickness of about 175 feet $(54 \mathrm{~m})$. In most places it has been greatly thinned by deformation.

The Wolsey consists largely of greenish-gray, waxy, fissile, silty and sandy shale. Bedding surfaces of the sandy beds are usually curved and cracked and show mud-crack casts, worm trails, and worm-burrow casts. Near its base, the formation con- 
tains thin beds of quartzite. Thin irregular beds of limestone and calcareous siltstone as much as 3 feet $(1 \mathrm{~m})$ thick are interlayered with shale in the upper part and form a transitional sequence that grades into the overlying Meagher Limestone. At most places this transitional zone is covered, and the contact between the Wolsey and Meagher is arbitrarily placed at the base of the first thick limestone bed.

The shaly beds of the Wolsey are composed principally of small grains of chlorite, biotite, and quartz. Bedding surfaces are commonly veneered with yellow-brown mica that imparts a pronounced bright sheen to loose fragments. Small rounded pellets of glauconite are common in quartzite in the lower part of the formation.

\section{MEAGHER LIMESTONE}

The Meagher Limestone rests conformably on the Wolsey Shale. In a nearly complete section along the North Fork of Little Creek, in the south-central part of the area, the Meagher is about 500 feet $(152 \mathrm{~m})$ thick. In other places, only part of the formation is represented.

The upper and lower parts of the Meagher consist principally of gray and bluish-gray limestone that is distinctively mottled with small isolated patches and irregular seamlike networks of tan and orange calcite and dolomite. Near the base there are thin beds of dark-gray, fine-grained petroliferous limestone that contain abundant shells and shell fragments of trilobites and brachiopods. The middle part is made up largely of gray to light-gray microcrystalline limestone in beds as much as a foot $(30 \mathrm{~cm})$ thick. Locally, within this interval, sequences several feet (1 to $2 \mathrm{~m}$ ) thick are made up of alternating thin layers of siliceous dolomite and gray limestone. The dolomite layers weather out in slight relief, giving the rock a ribboned appearance. A few thin lenses of tan calcitic sandstone containing finely comminuted fossil fragments, and a few thin beds of conglomerate composed of angular to subrounded pebbles and cobbles of limestone in a matrix of calcitic sandstone, also are present in the middle part of the Meagher.

Fault-transported masses of Meagher Limestone are present in small klippen at Limekiln Mountain and Painted Hill and along the northwest border of the area in secs. 28 and 33, T. 17 N., R. 5 $\mathrm{W}$. The largest of these klippen, at Limekiln Mountain, is made up of about 250 feet $(76 \mathrm{~m})$ of bluish-gray mottled limestone and gray banded limestone from the lower and middle parts of the formation. In the klippe at Painted Hill, about 60 feet $(18 \mathrm{~m})$ of 
mottled limestone from the lower part of the Meagher rests in fault contact on a thin wedge of Lodgepole Limestone of Early Mississippian age. The klippe along the northwest border of the area consists of a thoroughly broken mass of mottled and banded limestone derived either from the lower or upper part of the Meagher.

Three large detached blocks of Meagher Limestone are present along the Eldorado thrust fault in the southwestern part of the area (pl. 1). The largest, which is about 800 feet $(244 \mathrm{~m})$ long and as much as 25 feet $(8 \mathrm{~m})$ thick, is in the SW1/4 sec. 12 , T. $15 \mathrm{~N}$., R. $5 \mathrm{~W}$. The blocks are composed of gray and bluish-gray mottled and banded limestone similar to that at Limekiln Mountain. Many smaller fragments of limestone, which resemble the Meagher, also are found along the Eldorado thrust fault from Willis Creek north to Roberts Mountain and beyond. They are intermixed with fragments of limestone that resemble the Madison Group of Mississippian age. The fragments range from a fraction of an inch (a few millimeters) to 10 feet $(3 \mathrm{~m}$ ) across and are generally somewhat rounded. The specific formation from which the smaller fragments have been derived usually cannot be determined from field examination; Paleozoic limestone from formations other than the Meagher and Madison may be represented.

Well-preserved Middle Cambrian fossils were found in the Meagher on the southwest slope of the klippe at Painted Hill in the NW1/4 sec. 23, T. 16 N., R. 5 W. (USGS Paleozoic loc. 3578-CO) and on the south side and slightly above the base of the klippe at Limekiln Mountain in the SE $1 / 4$ sec. 22, T. 16 N., R. 5 W. (USGS Paleozoic loc. 4496-CO). At these localities, A. R. Palmer (written commun., 1961, 1964, 1965) identified a trilobite fauna consisting of single species of Ehmania, Clappaspis, and Peronopsis and a single specimen of the long-ranging brachipod Dictyonina.

\section{MISSISSIPPIAN SYSTEM}

Rocks of the Mississippian System are represented in the area by small fault-transported blocks of Lodgepole Limestone and Mission Canyon Limestone of the Madison Group of Early and Late Mississippian age. Only two of the blocks, one of Lodgepole Limestone and the other of Mission Canyon Limestone, are large enough to map. The aggregate thickness of the mapped blocks is about 90 feet $(27 \mathrm{~m})$; thus, they constitute only a small fraction of the Madison Group. 


\section{MADISON GROUP}

LODGEPOLE AND MISSION CANYON LIMESTONES

A small wedge-shaped mass of Lodgepole Limestone is present beneath the body of Meagher Limestone along the east side of the small klippe at Painted Hill. This wedge is about 50 feet $(15 \mathrm{~m})$ thick and consists of thin beds of gray, tan-weathered, fine-grained clastic limestone separated by partings of tan calcareous mudstone. Some of the limestone beds contain veinlike lentils and nodules of light-brown chert. Fossils, abundant in beds of gray limestone near the middle of the limestone mass (USGS Paleozoic loc. 19061-PC), were identified by J. T. Dutro, Jr., and W. J. Sando (written commun., 1960) as echinodermal debris, indet.; actinocrinitid plate, indet.; Rylstonia sp., Spirifer cf. S. rowleyi Weller, Spirifer sp., and Punctospirifer? sp.

A large block of limestone caught along the Eldorado thrust fault in the south-central part of the area (pl. 1) is assigned to the Mission Canyon. This block, which is 700 feet $(213 \mathrm{~m})$ long and about 40 feet $(12 \mathrm{~m})$ thick, consists of light-gray, massive, thick-bedded, microcrystalline limestone. The rock contains abundant crinoidal debris and other fossil fragments too poorly preserved for identification.

Countless small detached fragments of limestone that resemble rocks of the Madison Group are found along the Eldorado thrust fault together with numerous fragments derived from the Meagher Limestone of Middle Cambrian age and perhaps also from other Paleozoic formations. It is difficult to identify the Madison fragments positively as Lodgepole or Madison Canyon, for none were found with recognizable fossils. However, the fragments consist of tan-weathered chert-bearing limestone similar to typical Lodgepole, and light-gray microcrystalline limestone much like typical Mission Canyon, and no doubt both formations are represented.

\section{JURASSIC SYSTEM}

The Jurassic System is represented by the Sawtooth Formation of Middle Jurassic age, the Swift Formation of Middle and Late Jurassic age, and the Morrison Formation of Late Jurassic age. The Sawtooth and Swift Formations constitute the Ellis Group. The Rierdon Formation, which lies between the Sawtooth and Swift Formations in other parts of Montana, is absent in the Wolf Creek area. The Jurassic formations have a maximum aggregate thickness of about 470 feet $(143 \mathrm{~m})$. 


\section{ELLIS GROUP}

SAWTOOTH FORMATION

The base of the Sawtooth Formation is marked by thrust faults, and the unit is not completely exposed. The maximum exposed thickness is about 100 feet $(30 \mathrm{~m})$. The Sawtooth consists of limestone, shale, siltstone, and sandstone of marine origin.

Beds of gray, tan-weathered massive bioclastic limestone separated by partings of gray, tan-weathered silty calcareous shale form the lower 30 feet $(9 \mathrm{~m})$ of the Sawtooth Formation. The beds of limestone in this sequence are as much as 5 feet $(1.5 \mathrm{~m})$ thick, and some have a fine wavy lamination that suggests algal origin. In some places the limestones are intensively brecciated, probably as a result of solution and collapse.

Overlying the basal limestones is a sequence of sandy limestone, shale, siltstone, and sandstone. The sandy limestone is a gray and purplish-gray, hard, massive, thick-bedded clastic deposit composed of small fossil fragments, dark-gray calcareous oolites, and grains of clear quartz and black chert. It forms beds as much as 6 feet $(2 \mathrm{~m})$ thick. In places, the limestone beds grade laterally to coarse breccias made up of large angular blocks of clastic limestone cemented with white calcium carbonate. These breccias, like those in the lower part of the formation, probably formed through a process of solution and collapse. The shales are dark gray, tan weathered, and calcareous, and form beds as much as a foot (30 $\mathrm{cm}$ ) thick. They are generally poorly fissile and jointed, and characteristically break into short thick blocks. Sandstone and siltstone beds are scarce and are usually less than a foot $(30 \mathrm{~cm})$ thick. The siltstone is gray, tan weathered, and calcareous, and commonly sandy with numerous visible grains of clear quartz. The sandstone is gray to buff, fine grained, and composed of clear colorless quartz grains in a cement of calcite.

Fossils are abundant in the limestone beds in the upper part of the Sawtooth, but most of them are thoroughly broken and not suitable for study. A bed of sandy limestone at the top of the formation contains inch-size fragments of the pelecypod Camptonectes sp. and the crinoid Astarte sp.

SWIFT FORMATION

The Swift Formation rests disconformably on the Sawtooth Formation and is about 100 feet $(30 \mathrm{~m})$ thick. The Swift consists of conglomerate, shale, and sandstone of marine origin.

A bed of conglomerate, as much as 6 inches $(15 \mathrm{~cm})$ thick, is 
present locally at the base of the Swift. It consists of well-rounded pebbles of tan quartzite and black chert, as much as 2 inches ( 5 $\mathrm{cm}$ ) across, and smaller pebbles of light-gray limestone in a matrix of fine-grained calcareous sandstone.

Above the basal conglomerate is about 40 feet $(12 \mathrm{~m})$ of darkgray finely micaceous shale containing thin beds and lenses of fine-grained ripple-marked sandstone. The sandstone lenses contain thin films and streaks of bluish-weathering shale. In places, the shale contains abundant worm-burrow casts, a few poorly preserved pelecypod shells, and, at the base, water-worn belemnites.

The upper 60 feet $(18 \mathrm{~m})$ of the Swift consists mainly of thick beds of gray, brown-weathered, fine-grained sandstone composed of grains of colorless quartz, gray and black chert, and green glauconite in a cement of calcite and clay. Small specks of yellow limonite probably represent altered pyrite grains. In places, partings of dark-gray micaceous shale are present between the sandstone layers. Brown and black prints of driftwood and discontinuous laminae of carbonaceous material are common in the sandstone beds, ripple marks and load casts are present on many bedding surfaces, and some of the sandstone layers have poor crossbedding.

\section{MORRISON FORMATION}

The Morrison Formation lies conformably on the Swift Formation and is about 270 feet $(82 \mathrm{~m})$ thick. The Morrison consists of sandstone, siltstone, mudstone, and limestone of continental origin.

The lower 30 feet $(9 \mathrm{~m})$ of the Morrison is made up of gray, buff-weathered, marly, freshwater limestone and grayish-green mudstone. The limestone beds are as much as 3 feet $(1 \mathrm{~m})$ thick and are composed of closely packed rounded masses of gray limestone in a matrix of grayish-green mudstone. The mudstone is hard, blocky, and indistinctly bedded, and forms beds as much as 3 feet $(1 \mathrm{~m})$ thick.

Above the lower sequence of limestone and mudstone is about 240 feet $(73 \mathrm{~m})$ of mudstone, siltstone, and sandstone. The mudstones and siltstones are predominantly greenish gray, but some are light gray, others are red, and a few are purple. They are moderately to highly calcareous, are hard and thinly laminated, and form beds as much as 3 feet $(1 \mathrm{~m})$ thick. The sandstone is mostly light gray and weathers to shades of brown and tan. It forms lenticular beds as much as 30 feet $(9 \mathrm{~m})$ thick. The sand- 
stone is composed mainly of small grains of quartz, chert, and quartzite cemented with crystalline calcite. Commonly it is speckled with yellowish-brown limonite that probably represents altered grains of pyrite. A bed of gray to black carbonaceous mudstone, as much as 10 feet $(3 \mathrm{~m})$ thick, is usually present at or near the top of the Morrison.

\section{CRETACEOUS SYSTEM}

Rocks assigned to the Cretaceous System include the Kootenai and Blackleaf Formations of Early Cretaceous age and the Marias River Shale, Telegraph Creek Formation, Virgelle Sandstone, Two Medicine Formation, and St. Mary River Formation of Late Cretaceous age. The Blackleaf Formation and Marias River Shale constitute the Colorado Group. The maximum aggregate thickness of the Cretaceous formations is about 8,600 feet $(2,621 \mathrm{~m})$.

\section{KOOTENAI FORMATION}

The Kootenai Formation rests disconformably on the Morrison Formation and has an average thickness of about 700 feet (213 $\mathrm{m})$. It consists of varicolored sandstone, siltstone, mudstone, and limestone of continental origin.

At the base is a hard massive quartzitic sandstone 25 to 50 feet $(8$ to $15 \mathrm{~m})$ thick. The rock is light gray, weathers grayish orange, is thick bedded and, in places, crossbedded. It is composed of small grains of quartz and a few scattered grains of gray chert and feldspar in a colorless silica cement. Millimeter-size specks of yellowish-brown limonite probably represent altered grains of pyrite.

Overlying the basal sandstone is a medial unit of mudstone, siltstone, sandstone, and limestone 400 to 450 feet (122 to $137 \mathrm{~m}$ ) thick. The mudstone and the siltstone are red and purplish red, are generally chunky to poorly fissile, and form beds as much as 6 feet $(2 \mathrm{~m})$ thick. Flakes of white mica are common on the bedding surfaces of the siltstone. The sandstone is reddish brown and purplish gray and forms lenticular beds as much as 20 feet $(6 \mathrm{~m})$ thick. It is composed of small grains of quartz, chert, feldspar, biotite, and magnetite in a cement of iron-stained clay. Dark-brown, sandy calcareous concretions as much as a foot (30 $\mathrm{cm}$ ) across are common in some sandstone beds in the upper part of the unit. Lenses of nodular limestone are present near the base. They are as much as 2 feet $(60 \mathrm{~cm})$ thick and are made up of gray and purplish-gray nodules of fine-grained limestone as much as 6 inches $(15 \mathrm{~cm})$ across in a matrix of red mudstone. 
Near the middle of the unit are several beds of gray, brownweathered, massive limestone that locally contain abundant but poorly preserved shells of freshwater gastropods and pelecypods. These beds are as much as 12 feet $(3.6 \mathrm{~m})$ thick, and some extend laterally as much as a mile $(1.6 \mathrm{~km})$.

The upper 200 to 250 feet ( 60 to $76 \mathrm{~m}$ ) of the Kootenai is made up of sandstone, siltstone, mudstone, and limestone. The sandstone is greenish gray, generally massive and indistinctly bedded, and forms lenticular beds as much as 50 feet $(15 \mathrm{~m})$ thick. It is composed of small grains of quartz, chert, feldspar, biotite, chlorite, and magnetite in a cement of finely divided chlorite and clay. The siltstone and the mudstone are red and green, thin- to thickbedded, and finely micaceous. They form beds as much as 3 feet $(1 \mathrm{~m})$ thick. Some of the green mudstone is soft and plastic when wet and is probably bentonitic. A conspicuous bed of dark-gray, brown-weathered, massive detrital limestone that has a pronounced fetid odor is present a few feet below the top of the formation. The bed is as much as 4 feet $(1.2 \mathrm{~m})$ thick. In places, this stratum consists of thin alternating beds of limestone and darkgray mudstone. Locally, the limestone contains abundant fragments of fossil gastropods and pelecypods.

\section{COLORADO GROUP}

The Colorado Group comprises about 1,350 feet (411 m) of rocks between the underlying Kootenai Formation and the overlying Telegraph Creek Formation. It is divided into a lower unit, the Blackleaf Formation, composed of three members, and an upper unit, the Marias River Shale, composed of four members. These units correspond to subdivisions of the Colorado Group on the Sweetgrass arch in western Montana (Cobban and others, 1959; 1976).

\section{BLACKLEAF FORMATION}

From the base upward, the Blackleaf Formation is composed of the Flood, Taft Hill, and Vaughn Members. The Bootlegger Member, which occurs at the top of the formation on the Sweetgrass arch, is absent in the Wolf Creek area. The average thickness of the formation is about 765 feet $(233 \mathrm{~m})$.

\section{Flood Member}

The Flood Member rests sharply on the Kootenai Formation with slight disconformity. The thickness, which varies considerably as a result of deformation, averages about 200 feet $(60 \mathrm{~m})$. 
The Flood is made up of a lower unit of quartzitic sandstone, a medial unit of ferruginous shale and siltstone, and an upper unit of carbonaceous sandstone. The rocks are of marine origin.

The lower unit is 10 to 30 feet $(3$ to $9 \mathrm{~m})$ thick and consists mainly of light-gray to tan, massive fine-grained quartzitic sandstone that weathers dark brown. The typical rock is composed of angular to subrounded grains of quartz and scattered grains of muscovite, biotite, chlorite, magnetite, and zircon in a colorless silica cement. In some places the unit consists of a single bed of massive quartzitic sandstone. More commonly, however, the unit is made up of several thick beds of massive sandstone separated by partings of dark-gray shale.

The medial unit is 145 to 165 feet $(44$ to $50 \mathrm{~m})$ thick and is mostly dark-gray to black fissile shale. A few thin beds of gray and olive-gray siltstone are present in the sequence. Bedding and joint surfaces in the rocks are stained with brown hydrous iron oxides. The shale contains dark-brown ironstone concretions as much as 6 inches $(15 \mathrm{~cm})$ long that break into small rusty chips; outcrops of the Flood are strewn with these fragments. The upper 25 to 30 feet $(8$ to $9 \mathrm{~m}$ ) of the unit consists of dark-gray shale, olive-gray siltstone, and fine-grained olive-gray sandstone in thin beds. In places, the top of this sequence is marked by a bed of gray, brown-weathered limestone as much as 4 inches $(10 \mathrm{~cm})$ thick.

The upper unit consists of a massive, fine-grained, thick-bedded, cliff-forming sandstone, 25 to 35 feet $(8$ to $11 \mathrm{~m})$ thick, which contains much woody plant material and poorly preserved leaf impressions. The rock is greenish gray, weathers light brown, and is composed of small grains of quartz, plagioclase feldspar, chert, muscovite, biotite, magnetite, and zircon in a cement of calcium carbonate and clay. Near the top there are usually a few thin layers of hard, massive, silica-cemented quartzitic sandstone.

\section{Taft Hill Member}

The Taft Hill Member lies conformably on the Flood Member. Its thickness, which varies as a result of deformation, averages about 190 feet $(58 \mathrm{~m})$. It consists of shale, siltstone, and sandstone of marine origin.

The lower part, about 90 feet $(27 \mathrm{~m})$ thick, is made up of thin beds of dark-gray fissile shale and olive-gray papery calcareous siltstone. Above the lower sequence is about 70 feet $(21 \mathrm{~m})$ of thinly layered dark-gray silty shale and olive-gray calcareous siltstone and sandstone. The sandstone beds are as much as 2 feet 
$(60 \mathrm{~cm})$ thick. At the top is a bed of greenish-gray sandstone, about 30 feet $(9 \mathrm{~m})$ thick, which is fine grained, thin bedded, and platy and contains distinctive dark-brown disc-shaped calcareous sandstone concretions as much as 3 feet $(1 \mathrm{~m})$ across. This sandstone bed is composed of small grains of quartz, plagioclase feldspar, chert, biotite, glauconite, muscovite, magnetite, and zircon in a cement of calcium carbonate.

Well-preserved invertebrate fossils are confined to a thin bed of fine-grained sandstone 5 feet $(1.5 \mathrm{~m})$ below the base of the upper sandstone unit. Fossil pelecypods collected from this horizon (USGS Mesozoic locs. D2194 and D2198) were identified by W. A. Cobban (written commun., 1959) as Ostrea anomiodes Meek and Crassatella? sp.

Glauconite is a minor constituent in the Taft Hill of the Wolf Creek area; in contrast, at the type locality on the Sweetgrass arch, the unit contains abundant glauconite (Cobban and others, 1976, p. 16-17).

\section{VAUghn Member}

The Vaughn Member rests conformably on the Taft Hill Member and has an average thickness of about 375 feet $(114 \mathrm{~m})$. It is composed of tuffaceous sedimentary rocks, bentonite, ash-fall tuff, and conglomerate, all of continental origin. Large amounts of crystal, lithic, and devitrified volcanic detritus characterize the Vaughn.

More than half the Vaughn consists of tuffaceous sandstone and siltstone in beds a few inches (several centimeters) to several feet (1-2 $\mathrm{m})$ thick. These rocks are light to dull gray, green, greenish gray, purplish brown, and reddish brown, are thin to thick bedded and locally crossbedded. They commonly are cemented with silica and are hard and quartzitic. Most of the beds are highly lenticular. However, a distinctive bed of light-greenish-gray, coarse-grained, thick-bedded sandstone about 120 feet $(37 \mathrm{~m})$ above the base of the member appears to be extensive. This bed, as much as 20 feet $(6 \mathrm{~m})$ thick, contains numerous grit-sized rock fragments and much woody plant material.

The sandstone and siltstone are composed of small grains of quartz, plagioclase feldspar, alkali feldspar, chert, biotite, chlorite, and magnetite, and small lithic grains formed of a crystalline mixture of quartz and feldspar. The lithic grains may represent fragments of devitrified glassy volcanic rocks. Most of the sandstone and siltstone are cemented with finely crystalline silica; a few are cemented with calcite and clay. 
Mudstone makes up perhaps a third of the Vaughn and is mostly dull gray, greenish gray, and dark green. It forms beds a fraction of an inch (a few millimeters) to 2 feet $(60 \mathrm{~cm})$ thick. Commonly the mudstone is hard, dense, and silicified and breaks into short chunky blocks. When struck with a hammer, the harder varieties break with conchoidal fracture. Much of the mudstone is thinly and delicately laminated in the manner of strata produced by the fall of finely divided pyroclastic debris in water, and no doubt it contains a large component of vitroclastic volcanic detritus. Diagenetic alteration of the vitroclastic material probably caused the striking silicification of the rocks. A few mudstone beds in the Vaughn are soft and friable and are probably bentonitic.

Thin beds of light-olive-green and pale-yellowish-green bentonite are present throughout the Vaughn and constitute perhaps as much as 15 percent of the member. They are mostly a few inches (several centimeters) thick, but some are as much as 2 feet $(60 \mathrm{~cm})$ thick. On the flanks of folds, the bentonite beds are intensely compressed, sheared, and thinned, commonly to the point of disappearance.

A lenticular bed of stream-channel conglomerate near the middle of the Vaughn, in the NE1/4 sec. 7, T. 15 N., R. 3 W., is as much as 15 feet $(5 \mathrm{~m})$ thick and has a lateral extent of about 150 feet $(46 \mathrm{~m})$. It is composed of well-rounded pebbles of white and pink quartzite, green argillite, and black chert in an orange-weathered sandy matrix. The pebbles are as much as 3 inches $(8 \mathrm{~cm})$ long.

On the north side of the valley of Little Prickly Pear Creek, in the NW1/4, sec. 31 , T. 15 N., R. 3 W., a 20 -foot (6-m)-thick bed of light-gray to white, tan-weathered, thinly laminated ash-fall tuff occurs near the middle of the member. The bed is cut out by faulting to the north, disappears beneath alluvium to the south, and crops out over a distance of about 200 feet $(60 \mathrm{~m})$. The tuff is hard, compact, and silicified and breaks into large chunky fragments.

A few thin lenses of dark-gray to black carbonaceous shale and lignite, as much as 6 inches $(15 \mathrm{~cm})$ thick, are present in the upper part of the Vaughn.

Fossils are not abundant in the Vaughn. Poorly preserved, woody plant material and fossilized wood are scattered throughout the upper part of the member. A single saurian bone fragment, perhaps part of the leg bone of a turtle, was found in a bed of siltstone approximately 40 feet $(12 \mathrm{~m})$ below the top of the 
member along Montana State Highway 287 in the NE1/4 sec. 2, T. 15 N., R. 4 W.

MARIAS RIVER SHALE

From the base upward, the Marias River Shale is made up of the Floweree Shale, Cone, Ferdig, and Kevin Members. The average thickness of the formation is about 580 feet $(177 \mathrm{~m})$.

\section{Floweree Shale Member}

The Floweree Shale Member rests disconformably on the Vaughn Member of the Blackleaf Formation. The Floweree varies greatly in thickness as a result of deformation and has thinned to disappearance in some places. The average thickness is about 60 feet $(18 \mathrm{~m})$. The member consists of shale, siltstone, sandstone, bentonite, and conglomerate of marine origin.

The Floweree is formed mainly of dark-gray moderately fissile shale. A few thin beds and lenses of gray siltstone and very fine grained sandstone are present in the lower part, and one or more thin beds of yellowish-orange bentonite ordinarily are found near the middle. On the eastern flank of the Craig anticlinorium (pl. 1), the middle part of the Floweree locally contains thin beds and lenses of olive-gray and tan siltstone, sandstone, and chert-pebble conglomerate that form a sequence 5 to 8 feet $(1.5$ to $2.4 \mathrm{~m})$ thick. The base of this sequence consists of a conglomerate several inches (several centimeters) thick composed of smooth flat pitted pebbles of light-gray and black chert as much as 3 inches $(8 \mathrm{~cm})$ across. The pebbles are set in a matrix of olive-gray silty to sandy shale. The shape and surface marking of these chert pebbles are unique. Scattered pebbles of this sort were found at several localities where the member consists entirely of marine shale and siltstone.

The only fossil recovered from the Floweree was an impression of a coarsely ribbed species of Inoceramus (W. A. Cobban, written commun., 1959) collected about 10 feet $(3 \mathrm{~m})$ below the top.

\section{Cone Member}

The Cone Member rests conformably on the Floweree Shale Member. The thickness of the Cone varies greatly as a result of deformation, and in several places it has thinned to disappearance. The average thickness is about 60 feet $(18 \mathrm{~m})$. The Cone consists of shale, siltstone, limestone, and bentonite of marine origin. 
At the base is a bed of hard olive-gray calcareous siltstone containing large septarian limestone concretions that weather light gray. The concretions are as much as 3 feet $(1 \mathrm{~m})$ across, and some contain fossil cephalopods. Above the concretionary bed is 1 to 2 feet (30 to $60 \mathrm{~cm}$ ) of dark-gray calcareous shale overlain by a bed of yellowish-gray micaceous bentonite as much as 3 feet $(1 \mathrm{~m})$ thick. The bentonite bed is overlain by some 50 feet $(15 \mathrm{~m})$ of thinly laminated, calcareous, dark-gray shale and gray siltstone that weather dark brownish gray. The siltstone beds are usually only a few inches (several centimeters) thick and are mostly in the upper part of the sequence. A few thin beds of yellowishorange bentonite are ordinarily interlayered with the shale. At the top of the Cone there is commonly about 10 feet $(3 \mathrm{~m})$ of olivegray calcareous sandstone and dark-gray calcareous shale in thin beds. In a few places, the top of the member is formed of thin beds of dark-gray, ledge-forming, clastic limestone. This limestone weathers light bluish gray, is slightly silty, and gives off a pronounced fetid odor when broken.

Invertebrate fossils are abundant in the Cone. In four collections (USGS Mesozoic locs. D2210, D2217, D2680, and $\mathbb{D} 2684$ ) W. A. Cobban (written commun., 1959, 1960) identified the cephalopods Sciponoceras gracile (Shumard) and Warinoceras reesidei Warren and the pelecypods Mytiloides mytiloides (Mantell) and Ostrea n. sp. Sciponoceras gracile occurs in limestone concretions at the base. Mytiloides mytiloides is common throughout the shale-siltstone sequence above the lower bentonite bed, and crushed and broken shells of this pelecypod are abundant in thin beds of clastic limestone that locally form the top of the Cone. Watinoceras reesidei and Ostrea n. sp. occur in the upper part of the member, and fish scales of Ichthyodectes sp. and the calcitic tests of smaller Foraminifera are abundant in thin beds of calcareous sandstone at and near the top.

\section{Ferdig MeMber}

The Ferdig Member rests conformably on the Cone Member and maintains a fairly constant thickness of about 160 feet ( $49 \mathrm{~m})$, although there is usually some variation as a result of deformation. The Ferdig is of marine origin and in most places consists of a lower unit that is predominantly shale and an upper unit that is mainly siltstone and fine-grained sandstone. To the west and southwest, the upper part of the Ferdig grades into sandstone.

The lower unit is about 35 feet $(11 \mathrm{~m})$ thick and consists mainly of thin beds of dark-gray to black, poorly to moderately fissile, 
noncalcareous shale and scattered beds of hard gray and darkgray siltstone and very fine grained sandstone. The siltstone and sandstone beds are generally less than 2 inches $(5 \mathrm{~cm})$ thick, and their bedding surfaces are irregular and wavy. They weather olive gray. Locally, the base of the Ferdig is marked by a bed of soft waxy pale-yellowish-gray bentonite as much as a foot (30 $\mathrm{cm}$ ) thick. In most places, a thin bed of hard thinly laminated gray siltstone is present near the middle of the lower unit. This siltstone, which characteristically breaks into small flat chips that weather light bluish gray, forms a distinctive marker bed. At the top of the lower unit is a bed of dark-gray silty shale, as much as a foot $(30 \mathrm{~cm})$ thick, that contains hard, oblate to disc-shaped, dark-gray ferruginous concretions as much as 5 inches $(13 \mathrm{~cm})$ across. These concretions weather a conspicuous reddish brown.

The upper unit is about 125 feet $(38 \mathrm{~m})$ thick and consists of olive-gray siltstone and sandstone and dark-gray silty shale in thin beds. The siltstone and sandstone increase in abundance upward. They are hard, and thinly laminated, and their bedding surfaces are ordinarily irregular, wavy, and coated with thin films of dark-gray waxy shale. Some of the bedding surfaces show welldeveloped ripple marks. The siltstone and sandstones characteristically break into small thin curved chips, and outcrops are usually strewn with these fragments.

Along the western flank of the Craig anticlinorium (pl. 1), the upper part of the Ferdig consists mainly of thin beds of sandstone. These beds have a distinctive lithology and fauna and were earlier accorded member rank and named the sandstone member of the Marias River Shale (Schmidt, 1972a, b). In the Sun River Canyon area, about 30 miles $(48 \mathrm{~km})$ northwest of the Wolf Creek area, Mudge $(1966 \mathrm{a}, \mathrm{b}, \mathrm{c} ; 1967)$ also grouped sandstone beds in the upper part of the Ferdig into a separate sandstone member. Recently, however, Mudge (1972, p. A67) has assigned these sandstones to the Ferdig Shale Member and considers them to represent a facies of the upper and middle parts of the Ferdig. In view of the local distribution of the sandstone unit, this assignment seems preferable, and accordingly these rocks are treated as part of the Ferdig in this report.

The sandstone unit reaches a maximum thickness of 90 feet (27 $\mathrm{m}$ ) along the southern boundary of the area and gradually thins to about 5 feet $(1.5 \mathrm{~m})$ in its northernmost exposures in the central part of the area. In most exposures, the sandstone unit consists of a lower shaly part, a middle sandy part, and an upper bed of conglomerate. 
The lower shaly part is composed of alternating beds of gray to dark-gray, thinly laminated shale and olive-gray, tan-weathered fine-grained sandstone. A few beds of sandy limestone are present near the base. The sandstone beds are as much as 3 feet $(1 \mathrm{~m})$ thick and are composed of small grains of quartz and chert cemented with calcite. The lower shaly part is about 50 feet $(15 \mathrm{~m})$ thick at the southern boundary of the area, gradually thins northward, and is absent in the central part of the area.

The middle sandy part consists largely of massive tan-weathered calcareous sandstone in beds as much as 5 feet $(1.5 \mathrm{~m})$ thick. Several thin beds of gray shale are interlayered with sandstone near the top. The sandstones are composed mainly of small grains of quartz, chert, biotite, and magnetite in a cement of calcite. A bed of calcareous sandstone about 2 feet $(60 \mathrm{~cm})$ thick that weathers a distinctive rusty brown locally is present near the middle. Thick beds of sandstone near the top commonly contain one or more zones of platy disc-shaped calcareous sandstone concretions. The concretions are as much as a foot $(30 \mathrm{~cm})$ thick and 5 feet $(1.5 \mathrm{~m})$ across, weather dark brown, and locally contain abundant fossils. The middle sandy part is about 40 feet $(12 \mathrm{~m})$ thick at the southern boundary of the area and gradually thins to about 5 feet $(1.5 \mathrm{~m})$ in its northernmost exposures in the central part of the area.

The conglomerate bed at the top of the sandstone unit is a few inches (several centimeters) to a foot $(30 \mathrm{~cm})$ thick and contains smoothly rounded pebbles of dark-gray chert and dull-green argillite that range from a fraction of an inch (a few millimeters) to as much as 2 inches $(5 \mathrm{~cm})$ across. The conglomerate is of variable texture, ranging from more than 90 percent pebbles in a fine sandstone matrix to sandstone containing only a sprinkling of peasized pebbles. The bed is highly distinctive and is probably the rock-stratigraphic equivalent of Bed $\mathrm{N}$ of Erdmann and others (1947) in the upper part of the Ferdig Member on the Sweetgrass arch and the conglomerate at the top of the Bighorn (Cardium) Formation in southwestern Alberta, Canada (Cobban and others, 1959, p. 2794-2795).

Fossils are locally abundant in the sandstone unit of the Ferdig. In seven fossil collections (USGS Mesozoic locs. D510, D2195, D2196, D2197, D2199, D2200, and D2204) from sandstone concretions near the top, W. A. Cobban (written commun., 1959) identified the pelecypods Cardium pauperculum Meek, Crassatella wyomingensis Sidwell, Legumen aff. L. ellipticum Conrad, Cymbophora emmonsi (Meek)?, Phelopteria aff. P. linguaeformis 
(Evans and Shumard), Inoceramus sp., Panope sp., and the gastropods Gyrodes depressa Meek and Faciolaria? sp. In addition, W. A. Cobban collected Inoceramus lamarcki Parkinson and Ostrea sannionis White from the bed of rusty-brown calcareous sandstone in the middle part of the sandstone unit.

\section{Kevin Member}

The Kevin Member rests conformably, or perhaps with slight disconformity, on the Ferdig Member. Its thickness varies considerably as a result of deformation; the average thickness is about 300 feet $(90 \mathrm{~m})$. The Kevin consists of shale, siltstone, sandstone, limestone, bentonite, and conglomerate of marine origin.

About 90 percent of the member is dark-gray to black fissile shale. Thin beds of gray and olive-gray siltstone are present in the lower part, and locally, near the base, are a few thin beds of gray and olive-gray sandstone. Many beds of yellowish-gray micaceous bentonite as much as a foot $(30 \mathrm{~cm})$ thick are present in the lower and upper parts, and thin discontinuous beds of concretionary limestone and zones of gray, tan-weathered ovoid to discoid limestone concretions are scattered throughout the member. The concretions are massive and septarian, as much as 3 feet $(1 \mathrm{~m})$ across, and commonly contain fossil cephalopods and pelecypods. Less conspicuous are dark-gray massive spindle-shaped limestone concretions as much as a foot $(30 \mathrm{~cm})$ long.

A thin bed of conglomerate, about a foot $(30 \mathrm{~cm})$ thick, consisting of small pellets of light-olive-gray phosphatic siltstone and rounded grains and small pebbles of gray and black chert in a matrix of dark-gray concretionary limestone is present near the middle of the Kevin along Montana State Highway 287 in the SE $1 / 4$, sec. 36, T. 15 W., R. 4 W. This distinctive bed is widespread on the Sweetgrass arch to the east, where it was described as Bed $F$ of Erdman and others (1947) and later named the MacGowan Concretionary bed by Cobban and others $(1959$, p. 2795). The bed was not observed elsewhere in the Wolf Creek area; it may be quite extensive but poorly exposed.

Invertebrate fossils are abundant in the Kevin and are represented by collections bearing USGS Mesozoic loc. Nos. D2202-03, D2205, D2208-09, D2213-14, D2666-74, D2678-79, D2685, D2687, D3657, D3660, D3838-39, and D4614-17. Cephalopods and pelecypods were identified by W. A. Cobban (written commun., 1959, 1960, 1962, 1965); a snail (Aporrhais) was identified by N. F. Sohl (written commun., 1965). Cobban recognized three faunal zones in the Kevin of the Wolf Creek area that correspond gen- 
erally to the lower, middle, and upper parts of the member. The fossils and the faunal zones to which they are assigned are as follows :

Zone of Inoceramus deformis (lower part of Kevin Member)

Cephalopods :

Scaphites impendicostatus Cobban

$S$. cf. S. preventricosus Cobban

Baculites mariasensis Cobban

B. sweetgrassensis Cobban

$B$. cf. B. sweetgrassensis Cobban

Pelecypod:

Inoceramus deformis Meek

Zone of Scaphites ventricosus (middle part of Kevin Member)

Cephalopods:

Scaphites ventricosus Meek and Hayden

S. tetonensis Cobban

Baculites asper Morton

Pelecypods :

Volviceramus involutus (Sowerby)

Pseudoperna congesta (Conrad)

Pholodomya papyracea Meek and Hayden

Zone of Scaphites depressus (upper part of Kevin Member)

Cephalopods :

Scaphites depressus Reeside

S. depressus Reeside var. stantoni Reeside

S. binneyi Reeside

$S$. sp.

Phlycticrioceras oregonense Reeside

Baculites codyensis Reeside

B. asper Morton

$B$. sp.

Eutrephoceras sp.

Pelecypods :

Volviceramus involutus (Sowerby)

$V$. cf. $V$. involutus (Sowerby)

$V$. aff. $V$. involutus (Sowerby)

Inoceramus stantoni Sokolow

I. aff. I. cardissoides Goldfuss

I. aff. I. tuberculatus Woods

Pseudoperna congesta (Conrad)

Turritella sp.

Anomia sp.

Zone of Scaphites depressus or zone of Scaphites ventricosus

Cephalopod:

Scaphite8 sp.

Pelecypods :

Inoceramus cf. I. koeneni Muller

I. sp. 
Ostrea sp.

Turritella sp.

Gastropod:

Aporrhais aff. A. meeki Whitfield

\section{TELEGRAPH CREEK FORMATION}

The Telegraph Creek Formation is transitional between the Kevin Member of the Marias River Shale, below, and the Virgelle Sandstone, above. The contact between the Telegraph Creek and the Kevin is placed at the base of the first persistent bed of silty sandstone above the dark-gray shale of the Kevin, but, because exposures are generally poor, this contact is usually difficult to recognize, and its exact location must be inferred. In general, the contact is marked by a pronounced change in color, from dark gray in the Kevin to yellowish gray and tan in the overlying Telegraph Creek. The thickness of the Telegraph Creek varies considerably as a result of deformation; the average thickness is about 330 feet $(100 \mathrm{~m})$.

The Telegraph Creek consists of marine shale and sandstone in thin beds. Sandstone becomes increasingly abundant upward, and the formation grades into the Virgelle Sandstone. The shales are dark gray, usually somewhat silty or sandy, poorly to moderately fissile, and weather light gray and tan. The sandstones are light gray, fine grained, thin bedded, and weather tan. They are composed of small grains of quartz, plagioclase feldspar, chert, biotite, magnetite, and zircon in a cement of calcium carbonate. Bedding surfaces are commonly curved or wavy and are coated with flakes of mica and films of dark shale. Well-developed ripple marks and mud-crack casts are present on some bedding surfaces, and some of the sandstones in the upper part of the formation have well-developed crossbedding. The sandstones characteristically break into small thin curved chips, and outcrops of the Telegraph Creek are usually strewn with these fragments.

Worm-burrow casts are locally abundant and are present throughout the formation. They are especially common on the upper surface of sandstone beds. The lower 40 feet $(12 \mathrm{~m})$ of the Telegraph Creek contains gray discoid calcareous claystone concretions as much as 3 feet $(1 \mathrm{~m})$ across. The concretions are generally nonseptarian, and their interiors are devoid of crystalline calcite. Some are highly fossiliferous.

Invertebrate fossils are locally abundant in the lower part and present though scarce in the upper part of the formation. From USGS Mesozoic locs. D2206, D2215, D2675-77, D2681-83, D3658- 
59, D3840, and D4608-13, W. A. Cobban (written commun., 1959, $1960,1962,1964)$ identified the following forms:

Lower part of Telegraph Creek Formation:

Cephalopods :

Clioscaphites vermiformis (Meek and Hayden)

C. saxitonianus (McLearn)?

C. novimexicanus (Reeside)?

C. sp.

Baculites codyensis Reeside

Pelecypods:

Inoceramus pontoni McLearn

I. cf. I. cordiformis Woods

I. sp.

Anomia subquadrata Stanton

A. sp.

Oxytoma sp.

Cymbophora sp.

Nuculana sp.

Cardium sp.

Upper part of Telegraph Creek Formation:

Pelecypods :

Inoceramus lundbreckensis McLearn

Cymbophora sp.

Gastropod:

Gyrodes sp.

Clioscaphites vermiformis is found in the lower 60 feet $(18 \mathrm{~m})$ of the Telegraph Creek and is especially abundant in calcareous claystone concretions near the base. This occurrence of the fossil indicates a significant lithostratigraphic change between the Wolf Creek area and areas further east in the Montana plains. W. A. Cobban (written commun., 1959) reported that $C$. vermiformis occurs about $100-200$ feet $(30-60 \mathrm{~m})$ below the top of the Kevin Member of the Marias River Shale on the Sweetgrass arch, and that the upper 100 feet $(30 \mathrm{~m})$ of the Kevin and the overlying Telegraph Creek Formation there are characterized by younger scaphite zones. Accordingly, the upper part of the Kevin on the Sweetgrass arch grades southwestward into, and is the timestratigraphic equivalent of, the Telegraph Creek Formation in the Wolf Creek area.

\section{VIRGELLE SANDSTONE}

The Virgelle Sandstone conformably overlies the Telegraph Creek Formation. The boundary is marked by a rather abrupt change from interbedded sandstone and shale of the Telegraph 
Creek to massive sandstone of the Virgelle. The thickness of the Virgelle ranges from 120 feet $(37 \mathrm{~m})$ in the southeastern part of the area to 160 feet $(49 \mathrm{~m})$ in the northern part.

The Virgelle consists of beds of fine- to medium-grained calcareous feldspathic marine sandstone. The lower half of the formation is generally composed of thick massive beds; the upper half is usually formed of many thin beds in which crossbedding is well defined. The sandstones are mostly light gray, pale green, or light grayish green and locally weather tan or grayish orange. They are composed of subrounded to subangular grains of quartz, chert, plagioclase feldspar, potassium feldspar, biotite, and magnetite bonded in a cement of calcite and clay. Small subrounded grains of green volcanic rock and a dark-green mineral, probably glauconite, are fairly abundant in some beds and impart a greenish cast to the rocks. Large calcareous sandstone concretions are present in the upper part of the formation. They weather dark brown and reddish brown, are as much as 8 feet $(2.4 \mathrm{~m})$ across, and are firmly cemented. Commonly they weather out as discrete masses and either cap small sandstone pedestals or lie loose on the surface.

The top of the Virgelle is commonly formed of one or more beds of olive-green, brown, or dark-reddish-brown magnetite-rich sandstone. The beds are a few inches (several centimeters) to 3 feet $(1 \mathrm{~m})$ thick, are firmly indurated, and form a prominent ledge as much as 8 feet $(2.4 \mathrm{~m})$ thick. The amount of magnetite, together with some ilmenite, in these beds is variable and ranges from as little as 10 or 15 percent in olive-gray sandstones to as much as 95 percent in the dark-reddish-brown beds. Typical dark-reddishbrown sandstone consists of about 95 percent magnetite and ilmenite and about 1 percent quartz, feldspar, chert, zircon, and sphene (titanite) in small rounded to subangular grains firmly bonded in a cement of hematite, chlorite, and clay.

Fossils are not abundant in the Virgelle. In a single collection (USGS Mesozoic loc. D2201), from a sandstone concretion near the middle of the formation, W. A. Cobban (written commun., 1959) identified the pelecypods Cymbophora arenaria (Meek), Malletia sp., Phelopteria n. sp., and Tellina sp.

Several specimens of Inoceramus lundbreckensis McLearn were collected by W. A. Cobban and J. R. Gill in 1961 from magnetiterich sandstone capping the Virgelle on the north side of Montana State Highway 200 (formerly State 20 ), about half a mile east of the Dearborn River, in the NW1/4 $\mathrm{SE}^{1 / 4} \mathrm{SE} 1 / 4$ sec. $16, \mathrm{~T} .17 \mathrm{~N}$, R. 5 W. According to Cobban (oral commun., 1961), this guide 
fossil occurs in the upper part of the Kevin Member and in the Telegraph Creek Formation on the Sweetgrass arch. The occurrence of $I$. lundbreckensis at the top of the Virgelle is therefore significant, for it probably indicates that the Virgelle Sandstone of the Wolf Creek area is considerably older than its rock-stratigraphic equivalent (the lower part of the Eagle Sandstone) in central Montana and that the base of the Virgelle is probably at least as old as the base of the Telegraph Creek Formation of the central Montana sequence.

\section{TWO MEDICINE FORMATION}

The Two Medicine Formation comprises two spatially separated rock sequences that differ greatly from each other in overall lithology. These two sequences, which are separated by a northwest-trending strip of highly deformed older rocks of Cretaceous and Jurassic age (pl. 1), are informally named the western and eastern facies on the basis of their geographic distribution in the area. The western facies consists largely of volcanic rocks; the eastern facies is composed mainly of sedimentary rocks.

\section{WESTERN FACIES}

The western facies is divided into a lower sedimentary member and an upper volcanic member. North of the Wolf Creek area, Viele and Harris (1965) assigned the name Two Medicine Formation to the sedimentary member and gave the name Big Skunk Formation to the rocks herein designated as the volcanic member. On geologic maps, however, that classification tends to obscure the fact that the volcanic rocks are stratigraphically equivalent to the upper part of the Two Medicine Formation in areas to the east and north, inasmuch as the volcanic rocks are spatially separated from the main body of the formation. The member ranking, as used in this report, is therefore preferable.

The western facies attains a maximum thickness of about 4,800 feet $(1,463 \mathrm{~m})$ south and west of the Reef thrust fault. North and east of the Reef thrust fault, the facies is about 3,600 feet $(1,097$ $\mathrm{m}$ ) thick at the south, thins gradually to the north, and is about 2,700 feet $(823 \mathrm{~m})$ thick at the northwestern boundary of the area.

\section{Sedimentary Member}

The sedimentary member rests conformably on the Virgelle Sandstone. The contact is sharp and distinct. The thickness of the member ranges from about 275 feet $(84 \mathrm{~m})$ in the southern part 
of the area to about 550 feet $(168 \mathrm{~m})$ at the northwest boundary. The member consists of sandstone, mudstone, carbonaceous shale, lignite, coal, bentonite, and fossiliferous mudstone of continental and brackish-water origin.

More than 60 percent of the member consists of gray, green, and tan sandstone that forms lenticular beds a few inches (several centimeters) to 55 feet $(17 \mathrm{~m})$ thick. The sandstones are fine to medium grained, thick bedded, locally crossbedded, and consist of small grains of quartz, plagioclase feldspar, chert, biotite, magnetite, and porphyritic volcanic rock (rare) in a cement of calcite and clay. Some of the thick sandstone beds in the lower part contain large dark-brown calcareous sandstone concretions, have a thin zone of magnetite-rich sand at the top, and closely resemble the Virgelle Sandstone.

The mudstones are gray, tan, and green. They are generally silty or sandy, poorly laminated, slightly calcareous, and in beds a few inches (several centimeters) to several feet (1-2 m) thick. Some are soft and friable and are probably bentonitic.

Thin beds of dark-brown to black carbonaceous shale, lignite, and coal and yellowish-orange bentonite are conspicuous in the lower part of the member. Ordinarily there are four or five carbonaceous beds. They are thinly laminated, as much as 3 feet (1 $\mathrm{m})$ thick, and lenticular. The bentonite beds are a fraction of an inch (a few millimeters) to 2 feet $(60 \mathrm{~cm})$ thick and are commonly interlayered with the carbonaceous rocks.

A few thin beds of green, gray, and brown fossiliferous mudstone are present in the lower 60 feet $(18 \mathrm{~m})$ of the member. They are as much as 2 feet $(60 \mathrm{~cm})$ thick and consist of internal molds and shells of small brackish-water pelecypods and gastropods in a matrix of gray or green mudstone or brown carbonaceous mudstone. In places, these beds consist almost entirely of shell material, forming coquinoid limestone. Fossil pelecypods from a limestone coquina about 5 feet $(1.5 \mathrm{~m})$ above the base of the sedimentary member (USGS Mesozoic loc. D2207) were identified as Corbula n. sp. by W. A. Cobban (written commun., 1959).

\section{Volcanic Member}

The volcanic member is 4,500 feet $(1,372 \mathrm{~m})$ thick in the southern part of the area, thins gradually northward, and is 2,200 feet $(671 \mathrm{~m})$ thick along the northwestern boundary. It rests with slight disconformity on the sedimentary member. The volcanic member consists of an interlayered assemblage of clastic volcanic uncks and lava flows, all of continental origin. It is divided into 


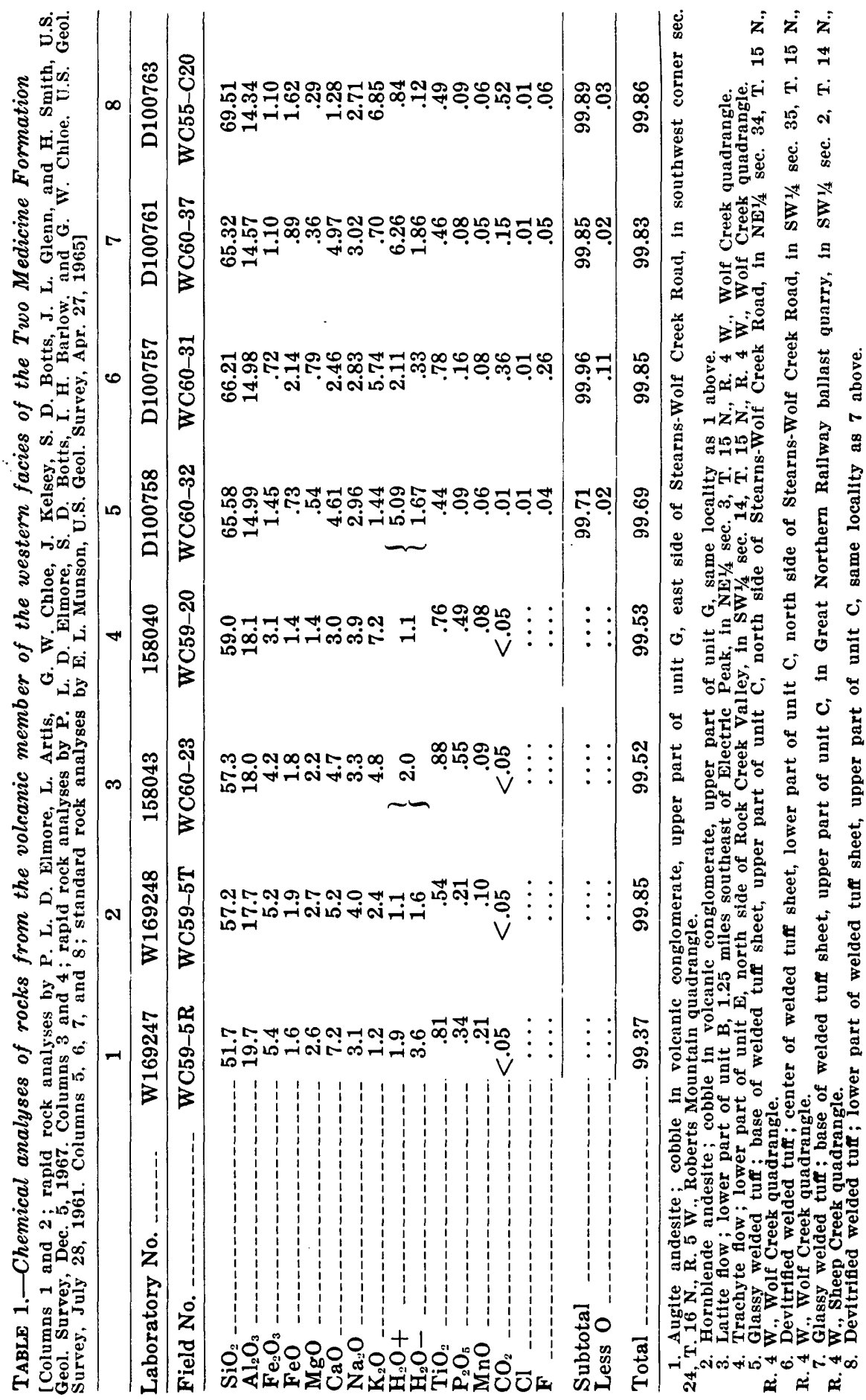


nine lithologic units, as follows, from oldest to youngest: $A$, clastic volcanic rocks; AA, clastic volcanic rocks; $\mathrm{B}$, latite flows; $\mathrm{C}$, ash-flow tuffs and clastic volcanic rocks; D, clastic volcanic rocks; $\mathrm{E}$, trachyte flow; $\mathrm{F}$, clastic volcanic rocks; $\mathrm{G}$, volcanic conglomerate; and $\mathrm{H}$, clastic volcanic rocks. Chemical analyses of rocks from the volcanic member are given in table 1.

Unit A (clastic volcanic rocks).-Unit A forms the base of the volcanic member in the central and southern parts of the area, south of Deadman Creek. It ranges in thickness from a featheredge to about 400 feet $(122 \mathrm{~m})$ and consists of volcanic sandstone, siltstones, mudstone, and tuff.

The sandstone is mostly green, gray, and brown and is in beds as much as 20 feet $(6 \mathrm{~m})$ thick. It is coarse grained, thick bedded, commonly crossbedded, and consists of small grains of porphyritic volcanic rock, plagioclase feldspar, augite, biotite, hornblende, quartz, and magnetite in a cement of chlorite, sericite, and clay. Some beds are locally conglomeratic and contain scattered pebbles of gray and brown andesite and latite as much as 2 inches $(5 \mathrm{~cm})$ across. The siltstone and mudstone are green and gray, generally sandy, blocky and indistinctly bedded, and form beds as much as 3 feet $(1 \mathrm{~m})$ thick.

South of Rock Creek, unit A contains distinctive beds of ashfall tuff and lapilli tuff. The most conspicuous bed of ash-fall tuff is as much as 10 feet $(3 \mathrm{~m})$ thick and is about 200 feet $(60 \mathrm{~m})$ above the base. This tuff is pink to brick red, fine grained and compact, and consists of devitrified glass shards and tiny crystals of plagioclase, biotite, and quartz. Several thin lenses of light-brownish-gray lapilli tuff are locally present in the upper half of the unit near Rock Creek. They are as much as 5 feet $(1.5 \mathrm{~m})$ thick and are composed of small angular fragments of andesite and latite in a matrix of fine-grained tuff.

Unit AA (clastic volcanic rocks).- Unit AA forms the base of the volcanic member in the northwestern part of the area, north of the Dearborn River. The unit occupies approximately the same stratigraphic position as unit $B$, interfingers with ash-flow tuffs in the lower part of unit $C$, and is probably somewhat younger than unit A. Unit AA ranges in thickness from a featheredge to about 200 feet $(60 \mathrm{~m})$ and consists of volcanic breccia, sandstone, siltstone, and mudstone.

Volcanic breccia forms about two-thirds of the unit. This rock is highly distinctive and is not found elsewhere in the volcanic member. The breccia is red and green, generally well consolidated, massive to thick bedded, and forms lenticular beds as much as $\mathbf{1 0}$ 
feet $(3 \mathrm{~m})$ thick that cut 2 to 3 feet $(60 \mathrm{~cm}$ to $1 \mathrm{~m})$ into underlying rocks. It is composed of angular to subrounded fragments of welded ash-flow tuff, porphyritic andesite and latite, and volcanic sandstone in a matrix of sandy volcanic mudstone. The fragments range from pea-sized grains to blocks as much as a foot $(30 \mathrm{~cm})$ across. The breccia beds probably represent stream-channel deposits derived from nearby bedrock.

Volcanic sandstone, in beds as much as 20 feet $(6 \mathrm{~m})$ thick, forms about a third of the unit. The sandstone is red and brownish red, coarse grained, thick bedded, commonly crossbedded, and composed of grains of porphyritic volcanic rock, devitrified welded tuff, plagioclase feldspar, augite, biotite, quartz, and magnetite in a cement of iron-stained clay.

Volcanic siltstone and mudstone are rare. They are mostly red and grayish red, generally blocky and indistinctly bedded, and form beds a few inches (several centimeters) to as much as 3 feet (1 m) thick.

Unit $B$ (latite flows).-Unit B is 300 to 650 feet (90 to $198 \mathrm{~m}$ ) thick south and west of the Reef thrust fault. North and east of the fault, the thickness of the unit ranges from 550 feet $(168 \mathrm{~m})$ in the southernmost exposure to about 5 feet $(1.5 \mathrm{~m})$ in the northernmost exposure (pl. 1).

Over most of its outcrop, unit B consists of two flows of identical texture and composition and roughly the same thickness. At the top of each flow is a vesicular zone 10 to 30 feet $(3$ to $9 \mathrm{~m})$ thick. Below the vesicular zones, the flows consist of massive porphyritic latite. Flow structure is absent. Locally, the base of the lower flow consists of a rubbly zone as much as 10 feet $(3 \mathrm{~m})$ thick. This zone is formed of large angular blocks of massive latite, some as much as 5 feet $(1.5 \mathrm{~m})$ across, in a matrix of green and gray volcanic mudstone and siltstone derived from the underlying rocks. The volcanic sediments were probably squeezed up and incorporated into the moving flow as it traveled over them. In most places, the flows are traversed by steep contraction joints that produce a rough columnar structure. This structure is particularly evident where the flows form steep cliffs, as along the summit of the high ridge known as The Reef (pl. 1).

The latite flows are gray to dark greenish gray and weather brown or brownish gray. They are porphyritic and consist of small phenocrysts of labradorite and augite in a microcrystalline groundmass of andesine, sanidine, augite, quartz, magnetite, and apatite. The labradorite phenocrysts are 1 to $4 \mathrm{~mm}$ long, weakly zoned, and range in composition from $\mathrm{An}_{50}$ to $\mathrm{An}_{58}$. The augite 
phenocrysts are prismatic and as much as $2 \mathrm{~mm}$ long. The vesicles at the top of the flows are spherical to ovular and range from about $1 \mathrm{~mm}$ to as much as $2 \mathrm{~cm}$ in diameter. Most of them are filled or lined with secondary minerals that include calcite, celadonite, quartz, and chalcedony. A chemical analysis of massive latite from the lower flow is given in column 3 of table 1.

Unit $C$ (ash-flow tuffs and clastic volcanic rocks).-Unit $\mathrm{C}$ attains a maximum thickness of about 750 feet $(229 \mathrm{~m})$ in the southern part of the area and thins gradually to about 175 feet $(53 \mathrm{~m})$ in its northernmost exposures. The unit consists essentially of interlayered sheets of ash-flow tuff. However, in a few places, lentils of volcanic sandstone, siltstone, and mudstone are present between the ash-flow sheets. These lentils range from a foot $(30 \mathrm{~cm})$ or less to as much as 20 feet $(6 \mathrm{~m})$ in thickness; one has a lateral extent of more than a mile $(1.6 \mathrm{~km})$. The thickest lentils are shown on the geologic map (pl. 1).

In the southern part of the area, south of Rock Creek, unit C is made up of five distinct sheets of ash-flow tuff. The four lower sheets each attain a thickness of more than 150 feet $(46 \mathrm{~m})$. The uppermost sheet is much thinner, having a maximum thickness of about 50 feet $(15 \mathrm{~m})$. North of Rock Creek, the ash-flow unit in most places consists of three separate tuff sheets, but locally it is made up of two tuff sheets, and at one locality it consists of four. All the tuff sheets thin gradually along strike and eventually pinch out, but on the whole they are remarkably uniform in thickness over long distances. The largest and most widespread sheet has a strike length of more than 15 miles $(24 \mathrm{~km})$ in the Wolf Creek area and continues southward in the adjoining Sheep Creek quadrangle. This tuff sheet attains a maximum thickness of about 200 feet $(60 \mathrm{~m})$. The ash-flow tuffs are varicolored in shades of red, purple, green, brown, and gray.

The thick sheets of ash-flow tuff have the zoned structure typical of this type of deposit. Where individual sheets are more than 60 feet $(18 \mathrm{~m})$ thick, they ordinarily consist of a central zone of massive densely welded tuff bounded above and below by nonwelded rubbly pumiceous tuff ; where the sheets are 30 to 60 feet $(9$ to $18 \mathrm{~m}$ ) thick, they usually have a central zone of partial welding bounded by nonwelded material; where the sheets are less than 30 feet $(9 \mathrm{~m})$ thick, they are composed entirely of nonwelded pumiceous tuff. The thickness of the central zone of welding and partial welding ranges from a featheredge to more than 140 feet $(43 \mathrm{~m})$.

The welded tuffs originated chiefly as a mixture of small glass 
shards and fragments of pumice that welded together to form hard compact massive rock. These glassy components are now almost completely devitrified to an aggregate of finely crystalline quartz and alkali feldspar. Minor constituents are small crystals of plagioclase feldspar, biotite, augite, magnetite, and quartz, and small fragments of porphyritic volcanic rock. The devitrified shards and pumice fragments are generally elongate, flattened, and warped and molded around the small crystal grains and rock fragments, imparting to the rocks the typical streaky foliate structure of welded tuff. The pumice fragments are generally small and are typically flattened into disc-shaped plates that range from about $1 \mathrm{~mm}$ to as much as $2 \mathrm{~cm}$ across. The nonwelded pumiceous tuffs are composed of the same constituents as the welded rocks, but their glassy constituents were not flattened and compacted; consequently, they are relatively soft and loosely consolidated:

At several places, at and near the base of thick welded zones in the larger tuff sheets, are small podlike masses of dark-gray to black glassy welded tuff that have escaped devitrification. The best exposures of the glassy welded tuff are on the north side of the Stearns-Wolf Creek Road in the $\mathrm{SE}_{1 / 4} \mathrm{SW}_{1 / 4} \mathrm{NE}^{1 / 4}$ sec. 34, T. 15 N., R. 4 W., where pods of glassy tuff are distributed irregularly at the base of the welded zone in the uppermost tuff sheet. The glass pods, which range from less than a foot $(30 \mathrm{~cm})$ to as much as 8 feet $(2.4 \mathrm{~m})$ across, grade outward through a transitional envelope of partially devitrified tuff into the surrounding devitrified tuff. The envelope of partially devitrified tuff surrounding the largest glass pod is about 3 feet $(1 \mathrm{~m})$ thick. A specimen of glassy welded tuff from this locality consists of small crystals of biotite, andesine $\left(\mathrm{An}_{35-45}\right)$, augite, and magnetite, and small accidental fragments of porphyritic volcanic rock in a matrix of glass shards and glassy pumice fragments. The shards and pumice fragments are bent and flattened, molded around the small crystal grains and rock fragments, and welded together to form a hard, compact, obsidianlike rock. The glassy matrix is traversed by many perlitic cracks.

Glassy welded tuff in the ash-flow unit was discovered by Adolph Knopf in 1947 in the Burlington Northern Railway ballast quarry, just south of the Wolf Creek area, in the Sheep Creek quadrangle. The quarry is in the SE $1 / 4 \mathrm{SW} 1 / 4$ sec. 2 , T. 14 N., R. 4 W. Barksdale (1951) gave a brief description of the glassy tuff at this locality, and later, Knopf (1957, p. 87) published an analysis of the rock. In that analysis, however, $\mathrm{K}_{2} \mathrm{O}$ and $\mathrm{H}_{2} \mathrm{O}$ were transposed because 
of typographical error. The glassy tuff in the railway ballast quarry is present in scattered podlike masses at the base of the welded zone of the thickest tuff sheet in the ash-flow unit. This tuff sheet is directly beneath the sheet that contains the pods of glassy tuff along the Stearns-Wolf Creek Road. The glassy tuff in the quarry is similar to that along the Stearns-Wolf Creek Road but contains small phenocrysts of labradorite and hornblende and lacks biotite.

The podlike masses of glassy tuff are probably the remnants of a once continuous thin layer of dense black glass that formed at the base of the welded zones of the tuff sheets. Layers of this sort form the base of welded tuff sheets in other regions, notably in Yellowstone National Park (Boyd, 1961, p. 394-395). Why the glassy tuff in the ash-flow sheets near Wolf Creek has escaped devitrification is not known. The presence of the glass is especially remarkable in view of the Late Cretaceous age of the rock.

Chemical analyses given in columns 5 and 7 of table 1 show that the glassy rocks along the Stearns-Wolf Creek Road and those in the railway ballast quarry are similar in chemical composition. They are characterized by a high content of $\mathrm{CaO}$ and $\mathrm{H}_{2} \mathrm{O}$ and a low content of $\mathrm{K}_{2} \mathrm{O}$. The devitrified rocks, on the other hand, as shown by analyses 6 and 8 , are characterized by a low content of $\mathrm{CaO}$ and $\mathrm{H}_{2} \mathrm{O}$ and a high content of $\mathrm{K}_{2} \mathrm{O}$. The chemical analyses appear to indicate that large amounts of potassium have migrated into and that large amounts of calcium and water have migrated out of the devitrified tuffs since their deposition. The glassy rocks are essentially unaltered, except for hydration of the glass, and should represent the original composition of the welded rocks.

Unit $D$ (clastic volcanic rocks).-Unit D is 700 to 1,000 feet $(213$ to $305 \mathrm{~m})$ thick in the main belt of the volcanic member that extends northwestward through the area. Above the Hicks Ranch thrust fault, in the southwestern part of the area, the unit attains a maximum thickness of about 1,500 feet $(457 \mathrm{~m})$.

In the main belt, unit $D$ consists of volcanic sandstone, conglomerate, siltstone, mudstone, tuff, and bentonite. Beds of maroon, purple, brown, and dark-green volcanic sandstone form more than half the unit. The sandstone is fine to coarse grained, thick bedded, commonly crossbedded, and forms beds as much as 20 feet $(6 \mathrm{~m})$ thick. It consists of grains of porphyritic volcanic rock, welded tuff, plagioclase feldspar, augite, magnetite, biotite, hornblende, and rare quartz in a cement of chlorite, sericite, and clay. Some beds of coarse-grained sandstone grade laterally into 
lenses of volcanic conglomerate as much as 6 feet $(2 \mathrm{~m})$ thick that consist largely of pebbles and cobbles of andesite, latite, and welded tuff in a matrix of coarse volcanic sandstone. Boulders as much as a foot $(30 \mathrm{~cm})$ long locally are present in the deposits. The volcanic siltstone and mudstone are green, gray, red, and purple and form beds as much as 4 feet $(1.2 \mathrm{~m})$ thick. They are commonly massive and poorly fissile and contain abundant sandsized grains and streaks of dark carbonaceous material. In the southern part of the area, one or two thin beds of pink to white ash-fall tuff are present near the middle of the unit and a thin bed of pale-green bentonite occurs near the base.

Above the Hicks Ranch thrust fault, the unit consists principally of thick beds of volcanic sandstone, conglomerate, and breccia. Thin beds of volcanic siltstone and mudstone are present locally. The sandstone is green and brown, thick bedded, arkosic, and commonly contains abundant granules and small pebbles of porphyritic volcanic rock. It forms beds as much as 20 feet $(6 \mathrm{~m})$ thick. The conglomerate is green and maroon, poorly layered, and forms beds as much as 30 feet $(9 \mathrm{~m})$ thick. It consists of pebbles, cobbles, and boulders of andesite, latite, and welded rhyolitic tuff in a matrix of coarse volcanic sandstone. The boulders are as much as 3 feet $(1 \mathrm{~m})$ long. The breccia is green and brown, massive and unsorted, and lacks visible layering. It forms lenticular beds as much as 60 feet $(18 \mathrm{~m})$ thick and large irregular masses as much as 200 feet $(60 \mathrm{~m})$ thick composed of angular fragments of andesite, latite, and quartz latite in a matrix of coarse lithic tuff. The breccia fragments are as much as 6 feet $(2 \mathrm{~m})$ across.

Unit $E$ (trachyte flow).-Unit $\mathrm{E}$ is 50 to 500 feet (15 to $152 \mathrm{~m}$ ) thick south and west of the Reef thrust fault. The unit is absent north and east of the Reef thrust fault and must wedge out beneath the fault.

The lower part of the flow is brownish-gray massive banded rock. The upper part is generally purplish red and is highly vesicular. The massive rock has a faint but persistent banding produced by thin alternating layers of light and dark rock as much as $1 \mathrm{~cm}$ thick. The layers are ordinarily alined parallel to the flow boundaries, but in places they are wavy and contorted. The banding is probably flow structure.

The massive trachyte is porphyritic and is made up of small phenocrysts of plagioclase feldspar and augite in a microcrystalline groundmass of sanidine, andesine, augite, magnetite, biotite, and apatite. The plagioclase phenocrysts are mostly less than 2 
$\mathrm{mm}$ long, are weakly zoned, and range in composition from andesine $\left(A n_{40}\right)$ to labradorite $\left(A n_{52}\right)$. Some of the plagioclase phenocrysts are surrounded by irregular rims of clear sanidine. The augite phenocrysts occur as short prismatic crystals mostly less than $1 \mathrm{~mm}$ long. The vesicular zone at the top of the flow is as much as 60 feet $(18 \mathrm{~m})$ thick. The vesicles are generally elongate and are alined parallel to the upper surface of the flow. They are as much as $4 \mathrm{~cm}$ long, and most are lined or filled with secondary minerals that include zeolites, chalcedony, and calcite. A chemical analysis of massive trachyte from the lower part of the flow is given in column 4 of table 1 . Chemically, the rock is characterized by a high content of $\mathrm{K}_{2} \mathrm{O}$.

Unit $F$ (clastic volcanic rocks).-Unit $\mathrm{F}$ is similar to unit $\mathrm{D}$. The only real difference is color: unit $D$ is characterized by reddish and purplish beds and unit $F$ by dark-olive-gray beds. North and east of the Reef thrust fault (pl. 1), where the trachyte flow of unit $\mathrm{E}$ is absent, the boundary between units $\mathrm{D}$ and $\mathrm{F}$ is gradational.

Unit $F$ has a maximum thickness of about 1,100 feet $(335 \mathrm{~m})$ in the southern part of the area, thins gradually to the north, and is about 300 feet $(90 \mathrm{~m})$ thick in its northernmost exposures. The unit consists chiefly of volcanic sandstone, conglomerate, siltstone, and mudstone. In the south-central part of the area, the unit contains a body of volcanic breccia.

The volcanic sandstone is mostly dark olive gray, but some is dark purplish gray and grayish red. It is generally coarse grained, thick bedded, crossbedded, and arkosic and forms beds as much as 10 feet $(3 \mathrm{~m})$ thick. Most of it consists of small grains of porphyritic volcanic rock, welded tuff, plagioclase feldspar, augite, and magnetite in a finely crystalline cement of chlorite, sericite, and clay. Scarce grains of biotite, hornblende, and quartz are present in some of the rocks. Some of the sandstone beds contain large amounts of heulandite that fills interstices and coats bedding surfaces. The heulandite gives the rocks a general reddish or pinkish cast.

Beds of sandstone in the upper part of the unit commonly grade into lenses of volcanic conglomerate, as much as 10 feet $(3 \mathrm{~m})$ thick, that fill shallow channels cut in underlying beds. The conglomerate consists of rounded clasts of andesite, latite, and welded tuff in a matrix of coarse volcanic sandstone. The clasts are mainly of pebble and cobble size but include a few boulders as much as 2 feet $(60 \mathrm{~cm})$ across.

The volcanic siltstone and mudstone are mostly olive gray, but 
in places they are grayish red and maroon. Commonly they are massive and poorly fissile and contain abundant sand-size grains. They form beds a few inches (several centimeters) to several feet (1-2 m) thick.

A separately mapped body of dark-brownish-gray volcanic breccia is present near the middle of the unit south and west of the Reef thrust fault (pl. 1). The breccia mass is broadly lenticular, is 5 to 150 feet ( 1.5 to $46 \mathrm{~m}$ ) thick, and is mainly composed of large angular blocks of trachyte and scattered small blocks of andesite and latite in a matrix of coarse lithic tuff. The blocks of trachyte, as much as 6 feet $(2 \mathrm{~m})$ across, form about 60 percent of the breccia. The trachyte has the same texture and composition as the trachyte of unit $\mathrm{E}$. The breccia is poorly consolidated, unsorted, and has no visible layering. The lack of internal sorting and the large size and angularity of the trachyte blocks suggest that the breccia was derived from a nearby source.

Unit $G$ (volcanic conglomerate).-Unit $G$ attains a maximum thickness of about 300 feet $(90 \mathrm{~m})$ in the southern part of the area and thins to a featheredge to the north. It consists largely of dark-greenish-gray and maroon volcanic conglomerate composed of abundant clasts of welded tuff, augite andesite, and hornblende andesite and fewer clasts of latite, quartz latite, quartzite, and petrified wood. The clasts are well rounded and closely packed, and the intervening spaces are filled with volcanic sandstone and sandy siltstone. The clasts range from pea-size granules to boulders as much as 2 feet $(60 \mathrm{~cm})$ across, but most are of pebble and cobble size and 1 to 6 inches $(2.5$ to $15 \mathrm{~cm})$ across.

The conglomerate is unsorted and lacks any visible sign of stratification or other internal features that might indicate a stream-laid origin. The contact of the conglomerate with the underlying rocks of unit $F$ is remarkably smooth and lacks the channeling or undulation that is ordinarily found at the base of streamchannel conglomerate. This feature and the coarse, unsorted, and generally structureless nature of the unit suggest that it may be a sheetflow deposit laid down on a nearly level plain or pediment close to the highland source from which it was derived.

Chemical analyses of cobbles of augite andesite and hornblende andesite from the conglomerate are given in columns 1 and 2, table 1 .

Unit $H$ (clastic volcanic rocks).-Unit $H$ is 550 to 1,050 feet $(168$ to $320 \mathrm{~m})$ thick and consists of volcanic sandstone, conglomerate, siltstone, mudstone, and ash-fall tuff. The generally lighter color of the rocks and the presence of thin beds of ash-fall 
tuff distinguish unit $\mathrm{H}$ from unit $\mathrm{F}$. In the northern part of the area, where the volcanic conglomerate of unit $G$ is absent (pl. 1), the contact between units $\mathrm{H}$ and $\mathrm{F}$ is placed at the base of the lowermost bed of ash-fall tuff in unit $\mathrm{H}$.

Green, gray, brown, and maroon volcanic sandstone, in beds that range from about a foot $(30 \mathrm{~cm})$ to 30 feet $(9 \mathrm{~m})$ in thickness, are common throughout unit $\mathrm{H}$. The rocks are fine to coarse grained, thick bedded, commonly crossbedded, and consist mainly of small grains of porphyritic volcanic rock, welded tuff, plagioclase feldspar, augite, and magnetite in a cement of chlorite, sericite, and clay. Scarce grains of hornblende, biotite, and quartz are present in some of the rocks. Some beds of coarse-grained sandstone are cemented with reddish-brown heulandite and in this respect are like some of those in unit F. Sandstone beds in the lower and upper parts of the unit locally grade into lenses of volcanic conglomerate a few inches (several centimeters) to 6 feet $(2 \mathrm{~m})$ thick. The conglomerate is composed of well-rounded clasts of andesite, latite, and welded tuff in a matrix of coarse volcanic sandstone. The clasts are predominantly of pebble and cobble size but range to boulders as much as a foot $(30 \mathrm{~cm})$ across.

Volcanic siltstone and mudstone form perhaps as much as half of the unit. They are generally green, gray, and maroon and form beds a fraction of an inch (a few millimeters) to several feet (1-2 $\mathrm{m})$ thick. They are generally sandy and contain visible grains of plagioclase feldspar, biotite, augite, and quartz. Some are calcareous.

As many as seven beds of ash-fall tuff are distributed throughout unit $\mathrm{H}$. The tuff beds are light greenish gray, brown, pink, and white and are a few inches (several centimeters) to 15 feet $(5 \mathrm{~m})$ thick. Most commonly they are thin bedded, hard and compact, and break into small slabs. The tuffs are composed of tiny angular crystals of quartz, feldspar, and biotite in a matrix of devitrified glass shards. In places, some of the thicker beds consist of alternating layers of soft friable bentonitic tuff and hard dense crystalline tuff.

Correlation and age.-The volcanic member of the Two Medicine Formation is compositionally similar to, and occupies roughly the same stratigraphic position as the Elkhorn Mountains Volcanics of Late Cretaceous age, which is widely distributed in and around the Elkhorn Mountains southeast of Helena, Mont. The volcanic member is considered to represent part of the northern extension of the Elkhorn Mountains volcanic field that once covered an area of some $15,000 \mathrm{~km}^{2}$ in northwest Montana, and, 
prior to the Late Cretaceous-early Tertiary orogeny, was presumably connected with the Elkhorn volcanic pile (Robinson and others, 1968, p. 563 ; Klepper and others, 1971, fig. 4). The precise age limits of the Elkhorn Mountains Volcanics are unknown, for the lower part of the formation lacks diagnostic fossils and the top of the formation has been removed by erosion. On the basis of stratigraphic and paleontologic evidence, the Elkhorn Mountains Volcanics appears to be largely, if not entirely, of Campanian Age and is roughly correlated eastward with the Eagle Sandstone, Claggett Shale, and Judith River Formation of the central Montana sequence (Klepper and others, 1957, p. 37-38, fig. 3; Robinson and others, 1968, p. 566-567).

The age limits of the volcanic member of the Two Medicine Formation are also not well defined, for diagnostic fossils have not been found in the member or in immediately adjoining rocks. However, some indication of the age of the base of the volcanic member is provided by stratigraphic and paleontologic evidence in underlying rocks. In the Wolf Creek area, the lower part of the Telegraph Creek Formation contains the cephalopod Clioscaphites vermiformis (Meek and Hayden) and the top of the Virgelle Sandstone contains the pelecypod Inoceramus lundbreckensis McLearn. Contrarily, on the Sweetgrass arch, $C$. vermiformis is found $100-200$ feet $(30-60 \mathrm{~m})$ below the top of the Kevin Member (Niobrara equivalent) and I. lundbreckensis in the upper part of the Kevin and in the Telegraph Creek Formation. These relations indicate that the Telegraph Creek Formation and the Virgelle Sandstone of the Wolf Creek area are considerably older than equivalent rock-stratigraphic units in central Montana. Accordingly, the base of the Two Medicine Formation in the Wolf Creek area is probably older than the base of the Eagle Sandstone of central Montana, and the base of the volcanic member could be at least as old as the middle part of the Eagle of the central Montana sequence.

Additional evidence for dating the volcanic member comes from rocks of equivalent age outside the Wolf Creek area. According to J. R. Gill (written commun., 1962), ash-flow tuffs in the lower part of the member are probably equivalent in age to thin beds of bentonite in the basal part of the Claggett Shale, and beds of ashfall tuff in the upper part of the member are probably equivalent in age to thin beds of bentonite in the lower part of the Bearpaw Shale of central Montana. If these correlations are correct, the volcanic member would then range from roughly middle Eagle (lower Campanian) to middle Bearpaw (upper Campanian) of the 
central Montana sequence. This age assignment was adopted by Gill and Cobban $(1966$, pl. 3) in correlating the volcanic member with the Upper Cretaceous rocks of central Montana.

Gill and Cobban (1966, table 2, p. A35) also presented data that provide a basis for estimating the absolute age limits of the volcanic member. Relating the ammonite sequence of Upper Cretaceous rocks of the Western Interior to potassium-argon age determinations, they were able to estimate dates for the various ammonite zones, permitting calculation of the age span of Upper Cretaceous stages and rock-stratigraphic units. In the section of Upper Cretaceous strata along the Dearborn River, in the northwestern part of the Wolf Creek area, Gill and Cobban (1966, pl. 3 ) located the base of the Baculites cuneatus Range Zone, which has a median estimated age of 72.5 m.y., slightly above the top of the volcanic member, and located the base of the Baculites obtusus Range Zone, which has a median estimated age of 79.5 m.y., near the middle of the ash-flow tuff unit (unit C), about 300 feet $(90 \mathrm{~m})$ above the base of the volcanic member. The member therefore ranges in age from about 73 m.y. to about 80.5 m.y. and has an age span of about 71/2 m.y., according to Gill and Cobban's chronology.

The few radiometric age determinations so far obtained on rocks from the volcanic member appear to be unreliable. Robinson and Marvin (1967) obtained a potassium-argon age of $73 \pm 2$ m.y. on biotite and a potassium-argon age of $72 \pm 7 \mathrm{~m}$.y. on plagioclase feldspar from samples of glassy welded tuff in the lower part of the volcanic member in the Wolf Creek area. These age determinations are not in accord with the age of the volcanic member deduced by Gill and Cobban (1966, pl. 3) and are much younger than the median age of 78 m.y. obtained by Tilling and others $(1968$, p. 677) on hornblende from rocks low in the correlative Elkhorn Mountains Volcanics. These facts indicate that the dates obtained on the Wolf Creek glasses are minimum ages and that the glasses are actually several million years older than those dates suggest (Robinson and Marvin, 1967, p. 607; Robinson and others, 1968, p. 568).

The estimated age of the volcanic member and its probable correlation with rocks of other areas in Montana and Wyoming are shown graphically on plate 2 .

\section{EASTERN FACIES}

The eastern facies of the Two Medicine Formation rests conformably on the Virgelle Sandstone and is about 1,950 feet (594 
m) thick. The facies consists of a wide variety of sedimentary and volcaniclastic rocks, most of which are of continental origin.

The lower 400 feet $(122 \mathrm{~m})$ of the eastern facies is equivalent to the sedimentary member of the western facies and consists of sandstone, mudstone, conglomerate, carbonaceous shale, lignite, coal, bentonite, and fossiliferous mudstone. The sandstone is gray, green, and tan, fine grained, thick bedded, crossbedded, and in beds as much as 40 feet $(12 \mathrm{~m})$ thick. Most of the sandstone is calcareous and some beds contain large calcareous sandstone concretions. The mudstone is green and gray and in thin beds. It is commonly silty or sandy and is blocky and indistinctly bedded. Some is bentonitic. Thin short lenses of conglomerate, locally about 200 feet $(60 \mathrm{~m})$ above the base of the facies, are less than a foot ( 30 $\mathrm{cm}$ ) thick and are composed of smoothly rounded pebbles of chert, quartzite, limestone, and porphyritic volcanic rock. As many as 10 lensing beds of dark-brown to black carbonaceous shale, lignite, and coal in the lower 130 feet $(40 \mathrm{~m})$ of the facies are a few inches (several centimeters) to 6 feet $(2 \mathrm{~m})$ thick. Thin beds of yellowish-orange bentonite commonly are present in the carbonaceous layers. Beds of fossiliferous mudstone are confined to the lower 60 feet $(18 \mathrm{~m})$ of the facies. They are as much as 6 feet $(2 \mathrm{~m})$ thick and consist of the internal molds and shells of small brackish-water pelecypods and gastropods in a matris of green or gray mudstone or brown carbonaceous mudstone. Pelecypods collected from one of these beds (USGS Mesozoic loc. D2686) were identified by $\mathbb{W}$. A. Cobban (written commun., 1960) as Anomia micronema $\mathbb{M}$ eek and Hayden and Corbula cf. C. subtrigonalis $\mathbb{M}$ leek and Hayden.

The lower beds are overlain by about 150 feet $(46 \mathrm{~m})$ of volcanic sandstone, siltstone, mudstone, and ash-fall tufi. The volcanic sandstone is mostly dark grayish green, coarse grained, and thick bedded and forms beds a few inches (several centimeters) to 15 feet $(4.6 \mathrm{~m})$ thick. It consists of small grains of porphyritic volcanic rock, plagioclase feldspar, augite, biotite, and magnetite in a cement of chlorite, sericite, and clay. The base of the sequence is usually marked by a thick bed of dark-green conglomeratic sandstone that contains small rounded pebbles of porphyritic volcanic rock. The volcanic siltstone and mudstone are mostly grayish green, gray, and olive gray and in beds a few inches (several centimeters) to several feet $(1-2 \mathrm{~m}$ ) thick. They are generally sandy and blocky and indistinctly bedded. In most places, the top of the sequence consists of a distinctive bed of light-green, pink, and white ash-fall tuff 1 to 8 feet $(30 \mathrm{~cm}$ to 2.4 m) thick. The tuff is hard and compact, breaks with conchoidal 
fracture, and is composed of devitrified glass shards and small scattered grains of plagioclase feldspar, biotite, magnetite, and devitrified pumice. The tuff is probably equivalent to part of the ash-flow tuff unit (unit $\mathrm{C}$ ) in the volcanic member of the western facies.

Above the volcanic strata is about 800 feet $(244 \mathrm{~m})$ of nonvolcanic sandstone, siltstone, mudstone, limestone, and bentonite. The sandstone is green, gray, tan, and brown, fine to medium grained, thin to thick bedded, locally crossbedded, and in beds as much as 20 feet $(6 \mathrm{~m})$ thick. Most is calcareous, and some contains dark-brown calcareous sandstone concretions as much as 2 feet $(60 \mathrm{~cm})$ across. The sandstone consists of small grains of quartz, chert, feldspar, augite, and magnetite in a cement of calcite and clay. The siltstone and mudstone are mostly green and gray, but some are maroon. They form thin beds and are commonly blocky and poorly bedded, although some are thinly laminated and resemble shale. A few thin beds of dark-bluish-gray carbonaceous mudstone and pale-green bentonite are usually present in the lower part of the sequence, and several thin beds of light-gray nodular limestone are present in the upper part.

The upper 600 feet $(183 \mathrm{~m})$ of the eastern facies consists mainly of clastic volcanic rocks, of which more than half are variegated beds of volcanic sandstone as much as 30 feet $(9 \mathrm{~m})$ thick. The sandstone is fine to coarse grained, thick-bedded, commonly crossbedded, and consists of grains of porphyritic volcanic rock, devitrified welded tuff, plagioclase feldspar, augite, biotite, and magnetite in a cement of chlorite, sericite, and clay. Dinosaur bone fragments and pieces of petrified wood are present locally in these beds. Some of the coarse sandstone beds in the lower part of the sequence contain thin lenses of volcanic conglomerate made up of small rounded pebbles of andesite, latite, and devitrified welded tuff. Beds of green and gray volcanic siltstone and mudstone, as much as 6 feet $(2 \mathrm{~m})$ thick, are interlayered with the volcanic sandstone. The siltstone and mudstone are commonly massive or indistinctly bedded and contain abundant sand-size grains. Some of the mudstone contains nodular limy concretions as much as 4 inches $(10 \mathrm{~cm})$ across, and thin beds of dark-gray, orange-weathered nodular limestone are interlayered with green mudstones near the top of the sequence. Some of the limy beds contain internal molds of freshwater gastropods. As many as four thin beds of ash-fall tuff are found at widely spaced intervals in the sequence. They are white and light greenish gray, hard and compact, and as much as 4 feet $(1.2 \mathrm{~m})$ thick. These tuffs are probably equivalent to some 
of the beds of ash-fall tuff in unit $\mathrm{H}$ of the volcanic member of the western facies.

\section{ST. MARY RIVER FORMATION}

The main mass of the St. Mary River Formation lies conformably on the western facies of the Two Medicine Formation and is about 1,200 feet $(366 \mathrm{~m})$ thick. A thin sequence of rocks assigned to the St. Mary River Formation is present in places beneath the Adel Mountain Volcanics of Lyons (1944) in the eastern part of the area. This sequence has a maximum thickness of about 60 feet $(18 \mathrm{~m})$, represents the lowermost part of the St. Mary River Formation, and rests conformably on the eastern facies of the Two Medicine Formation.

The main body of the St. Mary River is composed of sandstone, siltstone, mudstone, and tuff and is largely of continental origin. Beds of sandstone constitute about 40 percent of the formation. They are green, gray, and tan, fine to medium grained, thin to thick bedded, locally crossbedded, and as much as 20 feet $(6 \mathrm{~m})$ thick. Most of the sandstone is composed of abundant small grains of feldspar and chert and scarce grains of quartz and magnetite in a cement of calcite and clay. Several lensing beds of darkgreenish-gray volcanic sandstone, as much as 6 feet. $(2 \mathrm{~m})$ thick, are present in the lower 60 feet $(18 \mathrm{~m})$ of the formation west of the Reef thrust fault. Siltstone and mudstone make up about 60 percent of the St. Mary River and form beds a few inches (several centimeters) to 10 feet $(3 \mathrm{~m})$ thick. They are generally sandy or silty and are usually weathered at the surface to a distinctive soft punky gray or gray-green soil. Many of the mudstone beds, especially those in the upper part of the formation, contain small knobby calcareous concretions that weather out and are widely strewn over the ground. Several beds of purple and maroon mudstone and siltstone are ordinarily present in the lower and middle parts of the formation, and a few thin lensing beds of dark-gray carbonaceous mudstone usually occur in the lower part. A thin discontinuous bed of pale-green ash-fall tuff is found about 100 feet $(30 \mathrm{~m})$ below the top of the formation north of the Reef thrust fault.

A distinctive bed of grayish-green fossiliferous mudstone that contains brackish-water pelecypods and gastropods crops out 140 feet $(43 \mathrm{~m})$ above the base of the St. Mary River in exposures north of the Reef thrust fault. The bed is as much as 20 feet ( 6 m) thick and locally consists of a coquina made up almost entirely of the shells of the oyster Crassostrea wyomingensis (Meek) (W. 
A. Cobban, written commun., 1964). South and west of the Reef thrust fault, only scattered shells of this oyster are present in a zone approximately 120 to 140 feet ( 37 to $43 \mathrm{~m}$ ) above the base.

The rocks of the St. Mary River Formation that underlie the Adel Mountain Volcanics of Lyons (1944) consist of green, gray, brown, and $\tan$ tuffaceous sandstone, siltstone, mudstone, and conglomeratic sandstone. The sandstone is in beds as much as 20 feet $(6 \mathrm{~m})$ thick, is fine-grained, and contains large dark-brown calcareous sandstone concretions. It is composed of small grains of quartz, feldspar, pyroxene, magnetite, and porphyritic volcanic rock in a cement of calcite and clay. Locally the sandstone beds are conglomeratic, containing scattered pebbles of latite, andesite, and devitrified welded tuff as much as 3 inches $(8 \mathrm{~cm})$ long. The silstone and mudstone are grayish green and gray and form beds as much as 10 feet $(3 \mathrm{~m})$ thick. They are generally weakly consolidated, calcareous, and weather to a soft punky gray-green soil. Invertebrate fossils are locally abundant in the rocks. Fossils collected from a sandstone bed on the northwest flank of Coburn Mountain (USGS Mesozoic loc. D2216) were identified by W. A. Cobban (written commun., 1959) as the oyster Crassostrea wyomingensis (Meek), a species of the small clam Anomia, and the snail Melania? cf. M.? whiteavesi Stanton. Shells of Crassostrea wyomingensis are scattered throughout the sequence and are locally concentrated in beds of grayish-green mudstone.

\section{CRETACEOUS AND TERTIARY SYSTEMS}

The Cretaceous and Tertiary Systems are represented by the Willow Creek Formation of Late Cretaceous and early Paleocene age, the Adel Mountain Volcanics of Lyons (1944) of probable Paleocene age, and older colluvial deposits of probable Pliocene age. The maximum aggregate thickness of these rocks is about 4,320 feet $(1,317 \mathrm{~m})$.

\section{WILLOW CREEK FORMATION}

The Willow Creek Formation is gradational with the underlying St. Mary River Formation. In a rather ill-defined zone, 20 to 30 feet ( 6 to $9 \mathrm{~m}$ ) thick, gray-green beds of the St. Mary River grade upward into alternating red, green, and gray beds of the Willow Creek. The top of the Willow Creek is marked by thrust faults or by the present erosion surface, and an unknown thickness is missing. The maximum exposed thickness is about 1,400 feet $(427 \mathrm{~m})$. The Willow Creek consists of sandstone, siltstone, mudstone, pebble conglomerate, and nodular limestone of continental origin. 
About 40 percent of the Willow Creek is red, green, gray, and brown tuffaceous sandstone. These rocks are fine to coarse grained, mostly thick bedded, commonly crossbedded, and form beds as much as 20 feet $(6 \mathrm{~m})$ thick. Typical red sandstone near the middle of the formation consists of small grains of quartz, chert, plagioclase feldspar, augite, hornblende, biotite, magnetite, porphyritic volcanic rock, and devitrified welded tuff cemented with calcite, clay, and a red iron oxide, which is probably hematite. Quartz is universally present in the sandstone and forms as much as 30 percent of the constituent grains. In the lower 600 feet $(183 \mathrm{~m})$ of the formation, beds of red and brown arkosic sandstone locally contain thin lenses of conglomerate composed of small smoothly rounded pebbles of porphyritic volcanic rock, devitrified welded tuff, and chert. Beds of siltstone and mudstone constitute about 60 percent of the formation. They are red, purple, gray, and green, generally blocky and indistinctly bedded, and as much as 20 feet $(6 \mathrm{~m})$ thick. Most are calcareous. Red and green mottled mudstone is common in the lower part of the formation. Some of the gray and green mudstone contains small knobby light-gray calcareous concretions that weather out and are widely strewn over the ground. A few thin lenses of gray, pink-weathered nodular limestone are present in the lower part of the formation.

Fossils were not found in the Willow Creek Formation in the Wolf Creek area. In Alberta, Canada, the lower part of the Willow Creek is of Late Cretaceous age and the upper part is of Paleocene age (Tozer, 1956, p. 23-27).

\section{ADEL MOUNTAIN VOLCANICS OF LYONS (1944)}

The Adel Mountain Volcanics of Lyons (1944) lies unconformably on the eastern facies of the Two Medicine Formation and, in a few places, on basal strata of the St. Mary River Formation and has a maximum thickness of about 2,900 feet $(884 \mathrm{~m})$. The formation consists of clastic volcanic rocks and lava flows, all of continental origin. It is divided into five major lithologic units: $A$, volcanic breccia; $\mathrm{B}$, trachybasalt flows; C, trachyandesite flow; D, lacustrine deposits ; and E, volcanic conglomerate. Chemical analyses of these rocks are given in table 2.

Unit $A$ (volcanic breccia).-Unit A, incorporating a few thin flows of trachybasalt (unit B) and a flow of trachyandesite (unit C), constitutes the basal part of the Adel Mountain Volcanics of Lyons (1944) and has a maximum thickness of about 1,200 feet (366 m). 
TABLE 2.-Chemical analyses of rocks from the Adel Mountain Volcanics of Lyons (1944)

[Rapid rock analyses by P. L. D. Elmore, L. Artis, G. W. Chloe, J. Kelser, S. D. Botts, J. L. Glenn, and H. Smith, U.S. Geol. Survey, Dec. 5, 1967]

\begin{tabular}{|c|c|c|c|c|c|c|}
\hline & 1 & 2 & 3 & 4 & 5 & 0 \\
\hline Laboratory No. & W169255 & W169251 & W169253 & W169254 & W169250 & W169252 \\
\hline Field No. .....W W & V61-17H & WC61-9 & WC61-17D & WC61-17E & WC61-8 & WC61-10 \\
\hline $\begin{array}{l}\mathrm{SIO}_{2} \\
\mathrm{Al}_{2} \mathrm{O}_{3} \\
\mathrm{Fe}_{2} \mathrm{O}_{3} \\
\mathrm{FeO} \\
\mathrm{MgO} \\
\mathrm{CaO} \\
\mathrm{Na}_{2} \mathrm{O} \\
\mathrm{K}_{2} \mathrm{O} \\
\mathrm{H}_{2} \mathrm{O}+ \\
\mathrm{H}_{2} \mathrm{O} \\
\mathrm{T}_{2} \mathrm{O}_{2} \\
\mathrm{P}_{2} \mathrm{O}_{3} \\
\mathrm{MnO} \\
\mathrm{CO} \mathrm{O}_{2}\end{array}$ & $\begin{aligned} 51.3 \\
16.6 \\
6.0 \\
3.7 \\
3.5 \\
8.3 \\
3.6 \\
3.3 \\
1.8 \\
.53 \\
.60 \\
.61 \\
.12 \\
<.05 \\
\end{aligned}$ & $\begin{array}{r}52.0 \\
16.7 \\
2.6 \\
5.5 \\
4.8 \\
8.5 \\
2.9 \\
3.3 \\
1.7 \\
.49 \\
.85 \\
.43 \\
.15 \\
<.05 \\
\end{array}$ & $\begin{array}{r}54.0 \\
18.9 \\
4.4 \\
1.7 \\
1.8 \\
6.4 \\
4.8 \\
2.7 \\
3.8 \\
.48 \\
.42 \\
.34 \\
.18 \\
<.05 \\
\end{array}$ & $\begin{array}{r}54.0 \\
19.1 \\
3.7 \\
2.4 \\
1.6 \\
6.6 \\
2.5 \\
5.3 \\
1.9 \\
2.0 \\
.49 \\
.21 \\
.22 \\
<.05 \\
\end{array}$ & $\begin{array}{c}\mathbf{5 5 . 5} \\
\mathbf{1 9 . 0} \\
4.4 \\
\mathbf{2 . 7} \\
1.8 \\
7.1 \\
\mathbf{4 . 0} \\
\mathbf{3 . 5} \\
.69 \\
.31 \\
.39 \\
.35 \\
.15 \\
<.05 \\
\end{array}$ & $\begin{array}{r}05.1 \\
17.2 \\
2.5 \\
.56 \\
.95 \\
3.2 \\
5.4 \\
3.7 \\
.38 \\
.12 \\
.53 \\
.14 \\
.11 \\
<.05 \\
\end{array}$ \\
\hline Total & 99.96 & 99.92 & 99.92 & 100.02 & 99.89 & 99.89 \\
\hline
\end{tabular}

1. Augite trachybasalt; cobble in volcanic conglomerate, lower part of unit $\mathbf{E}, 1$ mile east of Coburn Mountain, in NW $1 / 4$ sec. 21 , T. 16 N.. R. : $\mathrm{W}$.. Mid Canon guadrangle.

2. Augite trachybasalt flow; part of unit $B$, : miles east of Flat Creek, in NE1/4 sec. 8, T. 17 N., R. 3 W., Coburn Mountain quadrangle.

3. Analcime-bearing augite trachyandesite; cobble in volcanic conglomerate, lower part of unit $\mathrm{E}$, same locality as 1 above.

4. Latite; cobble in volcanic conglomerate, lower part of unit $\mathrm{E}$, same locality as 1 above.

5. Augite trachyandesite flow; part of unit C, $:$ mlles enst of Flat Creek, in NE $1 / 4$ sec. $17, T .17$ N., R. 3 W.. Colourn Mountaln quadringle.

6. Quart\% latite; cobble in volcanic conglomerate. "iper part of unit $\mathrm{E}$, in SW $1 / 4$ sec. 8, T. 16 N., R. 3 W., Coburn Mountain quadrangle.

The unit consists chiefly of red, brown, and green volcanic breccia composed of angular blocks and fragments of trachybasalt and trachyandesite in a matrix of coarse tuff. The lower half of the unit is made up of coarse unsorted interfingering masses of breccia that contain blocks of trachybasalt as much as 15 feet $(5 \mathrm{~m})$ across. The upper half of the unit is less coarse, is crudely stratified, and contains a few thin lenses of volcanic conglomerate and sandstone. At several places, thick masses of breccia made up of closely packed angular blocks of dark-green trachybasalt are present in the lower part of the unit. A tuff matrix is lacking in these breccias, and they are extremely compact and firmly indurated. Breccia of this sort caps the summit of Coburn Mountain, and a large lens of the rock is present near the mouth of Sullivan Creek along the northwest border of the area. These rocks may represent flow breccia or block lava flows.

Most of the fragments in the breccia are trachybasalt. The typical rock is dark gray, coarsely porphyritic, and composed of abundant large prismatic phenocrysts of augite in a fine-grained groundmass of labradorite, sanidine, augite, magnetite, and apatite. Numerous small euhedral crystals of analcime, as much as 1 
$\mathrm{mm}$ across, and small crystals of olivine, usually altered to iddingsite or chlorite, are generally present in the groundmass.

Trachyandesite fragments are much less abundant than trachybasalt. They are gray, green, brown, and red, finely porphyritic, and typically composed of small phenocrysts of augite and andesine in a groundmass of andesine, sanidine, augite, magnetite, and apatite. Scattered small euhedral crystals of analcime are present in the groundmass of some of the trachyandesite fragments; a few contain small phenocrysts and groundmass grains of green hornblende.

The lower few feet of the breccia unit ordinarily contains fragments of sandstone and mudstone derived from the underlying Two Medicine and St. Mary River Formations; locally, the sediments have been squeezed up into the breccia and are molded around blocks at its base. This suggests that the deposit moved laterally across the Two Medicine and St. Mary River beds as a sheetlike mass or volcanic mudflow. The unsorted nature of the basal breccia, which is composed of volcanic materials ranging from ash-size particles to huge blocks 15 feet $(5 \mathrm{~m})$ across, is also indicative of a mudflow origin.

Unit $B$ (trachybasalt flows)..- Several thin flows of trachybasalt are present within unit A. They form short tabular and irregular bodies having a maximum thickness of about 30 feet $(9 \mathrm{~m})$. Some of the masses mapped as trachybasalt flows may actually represent sills or small irregular intrusive bodies. The trachybasalt flow rock is lithically similar to trachybasalt fragments in the breccia unit. A chemical analysis of a representative flow is given in column 2 of table 2. The high content of potassium is the chief chemical characteristic of the rock.

Unit $C$ (trachyandesite flow).-Four small tabular masses of trachyandesite overlying volcanic breccia in the northeast part of the area presumably are erosional remnants of a lava flow that once covered a much larger area. The maximum thickness of the flow is about 40 feet $(12 \mathrm{~m})$. The rock is gray, finely porphyritic, and composed of small phenocrysts of andesine and augite in a very fine grained groundmass of andesine, sanidine, augite, olivine, biotite, magnetite, and apatite. A chemical analysis is given in column 5 of table 2 . The rock is characterized by a high potassium content.

Unit $D$ (lacustrine deposits).-Lacustrine deposits range in thickness from a featheredge to about 500 feet $(152 \mathrm{~m})$, rest discordantly on the breccia unit, and consist of volcanic sandstone, siltstone, mudstone, and tuff.

Volcanic sandstone and siltstone, in beds a fraction of an inch 
(a few millimeters) to a foot $(30 \mathrm{~cm})$ thick, form about twothirds of the lacustrine unit. They are gray, brown, and tan, fine grained, thin bedded, and composed of small grains of porphyritic volcanic rock, plagioclase feldspar, augite, hornblende, and magnetite, and small fragments of dark-brown to black carbonaceous plant material in a cement of clay. Some of the sandstone and siltstone beds contain abundant but poorly preserved leaf impressions on their bedding surfaces. Beds of mudstone constitute about a third of the unit and are generally 1 or 2 inches (a few centimeters) thick. They are thinly and evenly bedded and commonly have small folds that are the result of slumping or gliding during deposition. Locally, a thin bed of pale-green ash-fall tuff, as much as 2 feet $(60 \mathrm{~cm})$ thick, is found a few feet $(1-2 \mathrm{~m})$ above the base of the unit.

The lacustrine deposits consist almost entirely of mineral and rock constituents from the Adel Mountain Volcanics and were probably erosionally derived from the Adel Mountain. The thin layering, slump and glide structures, fine grain size, and the presence of large amounts of organic debris suggest that the deposits were probably laid down in a shallow lake.

Unit $E$ (volcanic conglomerate).-The volcanic conglomerate unit rests with slight discordance on the lacustrine and breccia units. Its top is marked by the Coburn Mountain thrust fault, and an unknown thickness is missing. The maximum exposed thickness is about 1,200 feet $(366 \mathrm{~m})$.

The unit consists largely of thick lensing beds of red, purple, and brown volcanic conglomerate. Thin beds of red and purple volcanic sandstone, siltstone, and mudstone form a small part of the unit. The beds of conglomerate are generally massive and poorly sorted and are indistinctly bedded or lack visible layering. They are composed of rounded and subrounded clasts of trachybasalt, trachyandesite, latite, and quartz latite in a matrix of coarse volcanic sandstone. The clasts range from small pebbles less than an inch $(2.5 \mathrm{~cm})$ across to boulders as much as 2 feet $(60 \mathrm{~cm})$ across.

Most of the clasts consist of augite trachybasalt and analcimebearing trachybasalt that are similar to the trachybasalt in units $\mathrm{A}$ and $\mathrm{B}$. A chemical analysis of an augite trachybasalt clast is given in column 1 of table 2 .

Clasts of trachyandesite are fairly abundant. These rocks are similar to the trachyandesite in units $\mathrm{A}$ and $\mathrm{C}$. A chemical analysis of an analcime-bearing augite trachyandesite clast is given in column 3 of table 2. 
Latite forms many of the clasts in the conglomerate unit but is not as abundant as trachybasalt or trachyandesite. The latite clasts are gray and greenish gray, porphyritic, and composed of large phenocrysts of sanidine in a groundmass of sanidine, oligoclase, aegerine-augite, magnetite, and apatite. The sanidine phenocrysts are tabular, as much as. $1 \mathrm{~cm}$ long, and generally enclose small crystals of andesine. A chemical analysis of a latite clast is given in column 4 of table 2.

Cobbles and boulders of quartz latite are rare and were observed only in the upper part of the unit. The quartz latite is a distinctive light pinkish gray and is composed of large euhedral phenocrysts of pinkish-orange sanidine (probably sanidine cryptoperthite) and small phenocrysts of oligoclase in a fine-grained groundmass of sanidine, oligoclase, quartz, augite, biotite, hornblende, magnetite, and apatite. The sanidine phenocrysts are as much as $1 \mathrm{~cm}$ long and generally enclose small euhedral crystals of oligoclase. A chemical analysis of a quartz latite boulder is given in column 6 of table 2 .

The conglomerate unit extends into the adjoining Craig quadrangle to the southeast and is confined to the west side of the Adel Mountain volcanic field. All its rock constituents appear to have been locally derived from breccias, flows, dikes, and small intrusive bodies that form the main mass of the volcanic pile. The coarse, unsorted, and generally structureless nature of the unit suggests that it represents a huge alluvial fan deposited along the western margin of the volcanic field.

Age and correlation.-The age of the Adel Mountain Volcanics of Lyons (1944) is uncertain. Two species of fossil plants collected by Lyons $(1944$, p. 465) from the lower part of the conglomerate unit near Craig were identified as Viburnum montanum Knowlton and Plantophyllum sp. and dated as Late Cretaceous, probably Montanan. Structural and stratigraphic evidence accumulated in recent years suggests, however, that the volcanic rocks are probably younger than Montanan and very likely of Paleocene age.

The western border of the Adel Mountain volcanic field is marked by a zone of intense deformation in which rocks of the eastern facies of the Two Medicine Formation have been thrust over the volcanic rocks (pl. 1). Along the southern margin, on the other hand, major thrust faults apparently extend beneath the volcanic field and are older than the volcanic rocks (Barnett, 1916, pl. 1). Large folds associated with these faults also appear to pass beneath the volcanic cover. These relations presumably 
indicate that the volcanic rocks are intratectonic and were emplaced during the main episode of folding and thrust faulting in this part of Montana. The intratectonic setting of the Adel Mountain Volcanics is also indicated by the remarkable unconformity at their base. At the northern end of the volcanic field, in and northeast of the Wolf Creek area, the volcanic rocks rest unconformably on beds at or near the top of the Two Medicine Formation and, locally, on basal beds of the St. Mary River Formation. At the southern end of the volcanic field, southeast of the Wolf Creek area, the volcanic rocks rest unconformably on the Kootenai and Blackleaf Formations (Barnett, 1916, pl. 1). The unconformity cuts across about 4,000 feet $(1,219 \mathrm{~m})$ of rocks-the entire section between the Kootenai and St. Mary River Formations. It implies that uplift of this magnitude and concurrent removal of the strata took place before the volcanic rocks were erupted.

In the Wolf Creek area (pl. 1), and in the adjacent area to the north (Viele and Harris, 1965, figs. 2 and 4), the Willow Creek Formation of Late Cretaceous and Paleocene age is strongly deformed, suggesting that the folding and thrusting involving the Adel Mountain Volcanics in this region probably took place in Paleocene time. The thrust faults and folds that pass beneath the Adel Mountain volcanic field at its southern margin, and the uplift that preceded the eruption of the volcanic rocks, are considerably older, however, and quite possibly date back to Late Cretaceous time. The orogeny that encompassed emplacement of the volcanic rocks therefore probably occurred between Late Cretaceous and late Paleocene time. The tectonic setting of the volcanic rocks appears to indicate that they originated near the middle of the orogenic episode. If so, they are most likely of early Paleocene age.

Stratigraphic relations in the region immediately north of the Wolf Creek area provide the most convincing evidence that the rocks of the Adel Mountain Volcanics are probably of early Tertiary age. In this region, the Swallow Canyon and Dry Creek synclines contain complete sections of the St. Mary River Formation and thick sections of the Willow Creek Formation (Viele and Harris, 1965, fig. 4). Primary Adel Mountain Volcanics, or at least erosional debris shed from the volcanic field, must have once extended northwestward into the area now occupied by these structures, because small outliers of basal Adel Mountain breccia are only a few miles (several kilometers) to the southeast. However, intertonguing of Adel Mountain Volcanics with St. Mary River or Willow Creek strata has nowhere been observed (Viele and Harris, 1965, p. 414), a relation that would almost certainly be 
expected if the volcanic rocks were of Late Cretaceous age. This suggests that the Adel Mountain Volcanics is younger than the Willow Creek and is probably of Paleocene age.

The rocks of Adel Mountain Volcanics are similar in chemical and mineral composition to volcanic rocks of early Eocene age in the Absaroka Range east of Yellowstone National Park in northwestern Wyoming, and, in addition, they are not unlike some of the alkalic volcanic rocks of Eocene age in the Highwood and Bearpaw Mountains in the plains region of central Montana (Larsen, 1940 , p. 907 ; Lyons, 1944 , p. 470). The volcanic rocks of the Absaroka, Highwood Mountains, and Bearpaw Mountains belong to the Tertiary alkalic petrographic province of central Montana as defined by Larsen (1940). This chemical affinity does not, of course, provide a firm basis for correlation. Nevertheless, it tends to support the structural and stratigraphic evidence of a Paleocene age for the-Adel Mountain Volcanics.

\section{OLDER GOLLUVIAL DEPOSITS}

Older colluvial deposits form small patches near the front of the Lewis and Clark Range east of Roberts Mountain (pl. 1). Their maximum thickness is about 20 feet $(6 \mathrm{~m})$. They consist of coarse unconsolidated rock debris made up of angular blocks and fragments of Flathead Quartzite, and argillite and siltite of the Greyson Shale and Spokane Formation. Blocks of Flathead Quartzite in the deposits are as much as 8 feet $(2.4 \mathrm{~m})$ across. The material was presumably derived by mass wasting and perhaps by rockfall from outcrops at the top and along the flanks of the northeast-trending prong of Roberts Mountain. No doubt the deposits once formed a much more extensive blanket. The high elevation and nearly complete dissection of the surface upon which the deposits were laid down suggest that they are probably of Pliocene age.

\section{QUATERNARY SYSTEM}

The Quaternary System is represented by terrace gravel and glacial lake deposits of Pleistocene age, colluvial and landslide deposits of Pleistocene and Holocene age, and alluvium of Holocene age. These deposits are widespread (pl. 1) and have a maximum aggregate thickness of about 275 feet $(84 \mathrm{~m})$.

TERRACE GRAVEL

Terrace gravel lies on bench surfaces along the major streams. It is most widespread along the Missouri River, Little Prickly 
Pear Creek, the Dearborn River, the South Fork of the Dearborn River, and Flat Creek (pl. 1), where it is at elevations of 10 to 360 feet $(3$ to $110 \mathrm{~m}$ ) above stream level. The gravel is coarse, poorly sorted, and unconsolidated and is made up largely of wellrounded pebbles, cobbles, and boulders of a great variety of rocks derived from distant upstream sources. The material ranges in size from fine sand to large boulders as much as 3 feet $(1 \mathrm{~m})$ across; the bulk, however, consists of cobbles 2 to 3 inches (5 to $8 \mathrm{~cm}$ ) across. The chief rock types in the deposits are quartzite, quartzitic sandstone, argillite and siltite, monzonitic and granitic igneous rocks, porphyritic volcanic rocks, and limestone. The deposits are remnants of ancient flood-plain gravels that record downcutting by the streams in Pleistocene time. The maximum thickness of the deposits is about 20 feet $(6 \mathrm{~m})$.

\section{GLACIAL LAKE DEPOSITS}

Glacial lake deposits are found in the valleys of the Missouri River, Little Prickly Pear Creek, and Rock Creek, and on broad bench surfaces between these streams. They reach a height of as much as 280 feet $(85 \mathrm{~m})$ above the Missouri River. Their maximum thickness is about 40 feet $(12 \mathrm{~m})$. The deposits consist of light-gray, tan, and brown silt, clay, and sand in beds a fraction of an inch (a few millimeters) to as much as a foot $(30 \mathrm{~cm})$ thick. In places, the deposits are composed almost entirely of silt and clay in thin dark and light-brown laminae 1 to 3 inches (2.5 to $8 \mathrm{~cm}$ ) thick that resemble glacial varves. Small oblate and tubular calcareous concretions are locally abundant in the clay layers. Layers of fine- to medium-grained, well-sorted, weakly consolidated sand are locally present but constitute only a small part of the deposits. The sands are mainly composed of subrounded grains of quartz and chert and less abundant grains of feldspar and biotite. The glacial lake deposits were laid down in glacial Lake Great Falls, which formed when the Missouri River was dammed by a continental ice sheet east of Great Falls, Mont., in Wisconsin time (Calhoun, 1906, pl. 5 ; Alden, 1932, p. 29).

\section{COLLUVIAL DEPOSITS}

Colluvial deposits are widespread on steep to gentle slopes and on broad lowland surfaces at many localities. The maximum thickness of the deposits is about 15 feet $(5 \mathrm{~m})$. They consist of coarse unsorted unconsolidated angular rock debris made up of large and small fragments of massive igneous rock or resistant varieties of sedimentary rock, such as quartzite, quartzitic sandstone, argil- 
lite, siltite, and limestone. The material was shed from nearby outcrops on steep ridge and hill slopes and moved downward to its present position by slope wash and mass wasting. Some of the colluvial deposits are deeply dissected and are probably of Pleistocene age.

\section{LANDSLIDE DEPOSITS}

Landslide deposits are found chiefly along the front of the Lewis and Clark Range and at Limekiln Mountain, Painted Hill, and Elephant Mountain (pl. 1). The deposits consist of thick masses of coarse jumbled dislocated rock debris of local origin produced by processes of slump, rock creep, and earthflow on steep slopes. The surface of the deposits is normally rough and hummocky, and is marked by many small closed depressions. Along the front of the Lewis and Clark Range, the deposits consist of large blocks and smaller fragments of argillite, siltite, and quartzite derived from formations of the Belt Supergroup. At Limekiln Mountain and Painted Hill, the deposits are formed largely of broken masses of Meagher Limestone. The landslide deposits at Elephant Mountain are made up of broken masses of volcanic breccia derived from the Adel Mountain Volcanics of Lyons (1944) and blocks and fragments of sandstone, siltstone, and mudstone derived from the Two Medicine and St. Mary River Formations. Most of the landslide deposits are probably of Holocene age, but some, particularly those along the front of the Lewis and Clark Range, may have formed in Pleistocene time. The maximum thickness of the deposits is about 100 feet $(30 \mathrm{~m})$.

\section{ALLUVIUM}

The material mapped as alluvium consists chiefly of gravel, sand, silt, and clay in streambeds and on flood plains. It is poorly to moderately well sorted and unconsolidated. The thickest alluvium is found in the valley of Little Prickly Pear Creek near its junction with the Missouri River, where the maximum thickness may be as much as 100 feet $(30 \mathrm{~m})$. Alluvium in other major valleys is probably not more than 50 feet $(15 \mathrm{~m})$ thick; in smaller valleys it is mostly less than 20 feet $(6 \mathrm{~m})$ thick. The unit includes small amounts of slope wash deposited by small ephemeral streams on gentle slopes and in closed depressions and small amounts of colluvium accumulated along valley margins. Most of the alluvium is of Holocene age; buried alluvium in the valleys of Little Prickly Pear Creek and the Missouri River may be as old as Pleistocene. 


\section{INTRUSIVE ROCKS}

Intrusive rocks, mostly in the form of dikes and sills, are scattered throughout the Wolf Creek area. They include gabbro of Precambrian age; latite and trachyte of Cretaceous age; diorite, rhyodacite porphyry, and quartz monzonite porphyry of probable Cretaceous age; rhyolite of Cretaceous or Tertiary age; analcime gabbro, trachybasalt, and quartz monzonite porphyry of probable Tertiary age; and hornblende monzonite of Tertiary age. Table 3 gives chemical analyses of specimens of these rocks.

\section{PRECAMBRIAN}

GABBRO

Gabbro forms several sills in rocks of the Belt Supergroup in the southwestern part of the area. The largest, on the flanks of Rogers Mountain, is about 400 feet $(122 \mathrm{~m})$ thick. It is mainly intruded into the lower part of the Empire Formation, but near the nose of the Rogers Mountain syncline, it cuts gently downward across several hundred feet (about $100 \mathrm{~m}$ ) of beds and invades the upper part of the Spokane Formation. The gabbro is dark gray, brown weathered, medium grained, equigranular, and is composed of sodic labradorite, augite, biotite, hornblende, magnetite, quartz, myrmekite, and apatite. A chemical analysis is given in column 2 of table 3.

None of the gabbro sills in this area have been dated radiometrically. Just to the north, however, similar gabbro and diorite sills in the Belt Supergroup have been dated at $750 \pm 25$ m.y. old (Mudge, 1972, p. A75), or Precambrian Y. Presumably the gabbro sills in the Wolf Creek area are also of Precambrian $Y$ age.

\section{CRETACEOUS}

\section{LATITE}

A large irregular crosscutting sill of latite, as much as 1,500 feet $(457 \mathrm{~m})$ thick, intrudes the Telegraph Creek Formation, Virgelle Sandstone, and the sedimentary member of the western facies of the Two Medicine Formation near the southeast border of the area. The latite is dark gray, fine grained, and porphyritic, and is composed of phenocrysts of sodic labradorite in a groundmass of andesine, sanidine, augite, magnetite, quartz, and apatite. The rock is identical in texture and mineral composition with latite flows (unit B) in the volcanic member of the western facies of the Two Medicine Formation and, at one place, cuts upward to 


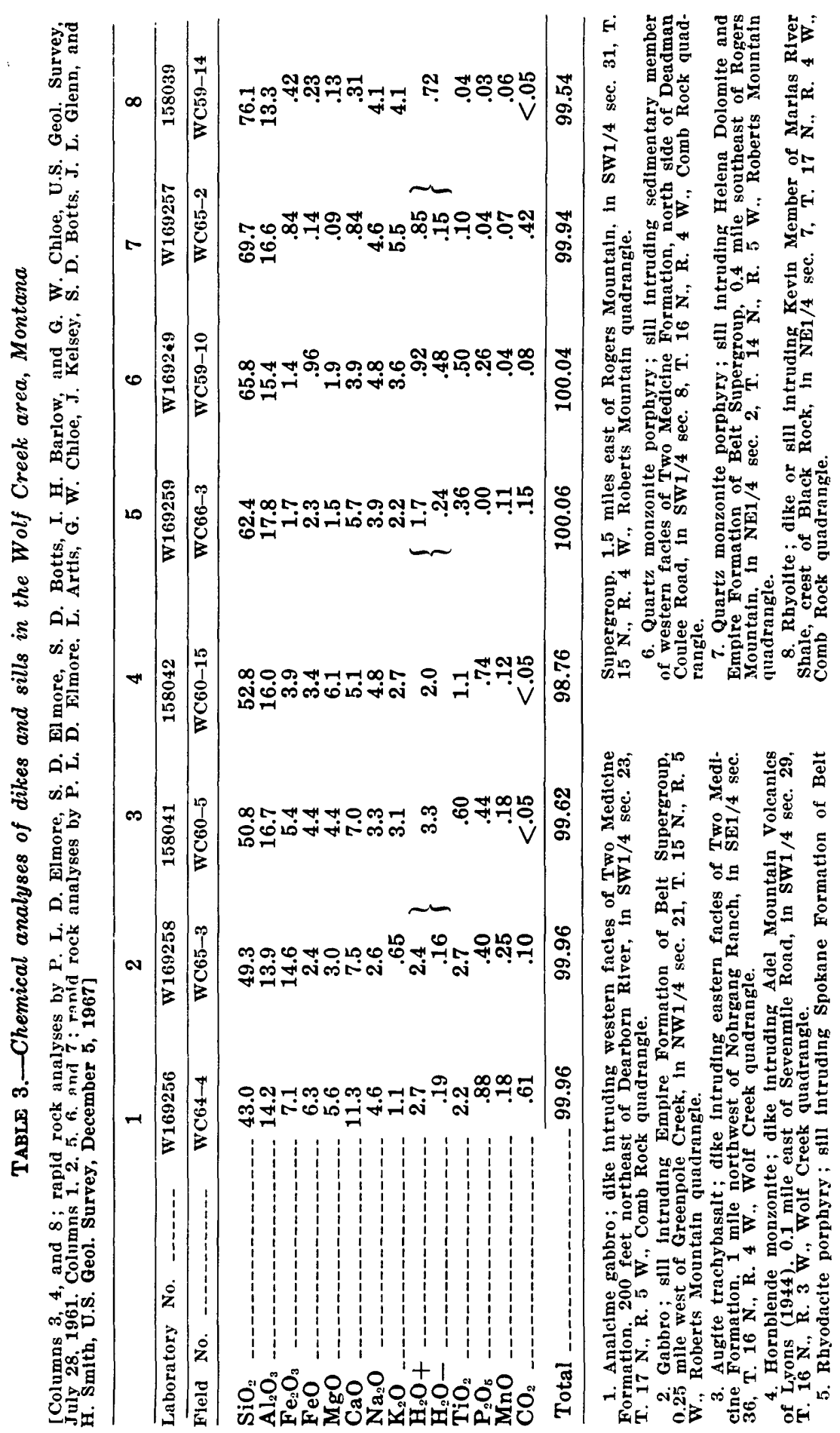


reach the base of the flow unit (pl. 1). Presumably the sill is contemporaneous with the flows and is of Late Cretaceous age.

\section{TRACHYTE}

A large sill of trachyte, as much as 200 feet $(60 \mathrm{~m})$ thick, intrudes the volcanic member of the western facies of the Two Medicine Formation in the south-central part of the area. The trachyte is purplish gray, massive, and finely porphyritic, and is composed of small phenocrysts of andesine-labradorite and augite in a groundmass of sanidine, andesine, augite, biotite, magnetite, and apatite. The rock is similar to the massive lower part of the trachyte flow (unit E) in the volcanic member, and several narrow offshoots project upward to the base of the flow. Presumably the sill is contemporaneous with the flow and is of Late Cretaceous age.

\section{PROBABLE CRETACEOUS}

Intrusive rocks of unknown but probable Late Cretaceous age include sills of diorite, rhyodacite porphyry, and quartz monzonite porphyry. These rocks, which mainly intrude formations of the Belt Supergroup, are chemically similar to, and may be approximately the same age as some of the rocks that form the Boulder batholith and its satellitic masses to the south and west. The batholithic rocks have yielded potassium-argon ages of 68 to 78 m.y. (Tilling and others, 1968) and are of Late Cretaceous age.

\section{DIORITE}

Thin sills of diorite intrude the Spokane Formation in the southwestern part of the area, and a thin sill invades the lower part of the Meagher Limestone in the south-central part. These sills are as much as 5 feet $(1.5 \mathrm{~m})$ thick and extend laterally as much as 3 miles $(5 \mathrm{~km})$. The typical rock is greenish gray, fine grained, and equigranular, and is composed of andesine, augite, hornblende, and biotite and small amounts of sanidine, quartz, magnetite, and apatite.

\section{RHYODACITE PORPHYRY}

Sills of rhyodacite porphyry intrude the Spokane Formation and the Greyson Shale in the southwestern part of the area. These sills attain a maximum thickness of about 225 feet $(69 \mathrm{~m})$ and extend laterally more than 2 miles $(3 \mathrm{~km})$. The typical rock is greenish gray and porphyritic and is composed of abundant pheno- 
crysts of oligoclase and hornblende in a fine-grained groundmass cf oligoclase, sanidine, quartz, hornblende, magnetite, and apatite. The oligoclase phenocrysts are generally rod shaped and as much as $6 \mathrm{~mm}$ long; the hornblende phenocrysts are prismatic and as much as $3 \mathrm{~mm}$ long. A chemical analysis is given in column 5 of table 3.

\section{QUARTZ MONZONITE PORPHYRY}

A thick crosscutting sill of quartz monzonite porphyry intrudes the Helena Dolomite and the Empire Formation on the north and east flanks of Rogers Mountain in the southwestern part of the area. The maximum thickness of the sill is about 250 feet $(76 \mathrm{~m})$. The typical rock is light pinkish gray, coarsely porphyritic, and consists of large phenocrysts of reddish-orange potassium feldspar (probably sanidine cryptoperthite) and smaller phenocrysts of oligoclase in a fine-grained groundmass of sanidine, oligoclase, quartz, augite, biotite, magnetite, and apatite. The phenocrysts of potassium feldspar are as much as $2 \mathrm{~cm}$ across. A chemical analysis is given in column 7 of table 3 .

\section{CRETACEOUS OR TERTIARY}

\section{RHYOLITE}

Several dikes and sills of rhyolite intrude rocks of Cretaceous age in the central and northern parts of the area. The largest body of rhyolite is a dikelike mass as much as 300 feet $(90 \mathrm{~m})$ wide and about $11 / 2$ miles $(2.4 \mathrm{~km})$ long that invades the Blackleaf Formation and Marias River Shale along the axis of the Craig antinclinorium (pl. 1). The intrusive rhyolite is light gray to white and finely porhyritic, and is composed of small phenocrysts of quartz and sodic oligoclase in a microcrystalline groundmass of oligoclase, sanidine, quartz, biotite, and magnetite. A chemical analysis of rhyolite from a dikelike mass at Black Rock, near the northern border of the area, is given in column 8 of table 3 .

The precise age of the rhyolite intrusions is unknown; they are either Late Cretaceous or early Tertiary. A sill of rhyolite that intrudes the lower part of the western facies of the Two Medicine Formation in the northwestern part of the area is offset by a small thrust fault and is cut by a dike of analcime gabbro of probable Tertiary age. These relations suggest that this particular rhyolite intrusion may be of Late Cretaceous age. 


\section{PROBABLE TERTIARY}

\section{ANALCIME GABBRO}

A dike of analcime gabbro intrudes the Telegraph Creek Formation, Virgelle Sandstone, and the lower part of the western facies of the Two Medicine Formation in the northwestern part of the area. The dike is subvertical, as much as 100 feet $(30 \mathrm{~m})$ wide, and more than 3,000 feet $(914 \mathrm{~m})$ long. The rock is dark gray, coarse grained, and equigranular, and is composed of augite, brown hornblende, biotite, labradorite, analcime, potassium feldspar, magnetite, apatite, and sphene. The potassium feldspar forms a narrow to broad mantle around some of the labradorite crystals. Analcime fills angular spaces between crystals of feldspar, augite, and hornblende and also is found as irregular masses replacing the feldspar crystals. A chemical analysis is given in column 1 of table 3 . Chemically, the rock is characterized by its low silica content. The dike cuts a sill of rhyolite and is probably of early Tertiary age.

\section{TRACHYBASALT}

Intrusive trachybasalt forms dikes, sills, and small irregular bodies in the eastern and northern parts of the area. The intrusions invade rocks of the eastern facies of the Two Medicine Formation and the Adel Mountain Volcanics of Lyons (1944). Most of the intrusions are dark-gray porphyritic augite trachybasalt composed of phenocrysts of augite and labradorite in a groundmass of labradorite, calcic andesine, sanidine, augite, magnetite, and apatite. Numerous small euhedral crystals of analcime and scattered crystals of olivine, biotite, and hornblende are present in the groundmass of some of the intrusions. A chemical analysis of a sample of a dike of augite trachybasalt is given in column 3 of table 3. The intrusive trachybasalt is similar to trachybasalt flows and fragments in the Adel Mountain Volcanics of Lyons (1944), and, like the volcanic rocks, is probably of Paleocene age.

\section{QUARTZ MONZONITE PORPHYRY}

Sills of quartz monzonite porphyry of probable Paleocene age in the northwestern part of the area are a few feet $(1-2 \mathrm{~m})$ to more than 1,000 feet $(305 \mathrm{~m})$ thick. The typical rock is light gray or light grayish orange and coarsely porphyritic; it is composed of large phenocrysts of potassium feldspar (probably sanidine cryptoperthite) and oligoclase in a fine-grained groundmass of sanidine, oligoclase, quartz, biotite, hornblende, magnetite, apatite, 
and sphene. The phenocrysts of potassium feldspar form stubby crystals as much as $2 \mathrm{~cm}$ wide and $4 \mathrm{~cm}$ long in some of the sills and thin tabular crystals as much as $8 \mathrm{~cm}$ long in others. A chemical analysis of one of the sills is given in column 6 of table 3.

Some of the sills intrude rocks of the Willow Creek Formation of Late Cretaceous and Paleocene age. Others are folded, a few are cut by small thrust faults, and several are intruded along thrust faults. These relations, though inconclusive, suggest that the sills may range in age from Late Cretaceous to Paleocene. A sill of quartz monzonite porphyry that crops out along the Middle Fork of the Dearborn River about 3 miles $(4.8 \mathrm{~km})$ west of the Wolf Creek area appears to be definitely of late Paleocene age. It is in secs. $2,3,11$, and $12, T .16$ N., R. $6 \mathrm{~W}$. and has been dated by the potassium-argon method as 58.3 m.y. old by H. H. Mehnert of the U.S. Geological Survey (U.S. Geol. Survey, 1971, p. A37). The age of this particular intrusion is especially significant, for the sill is intruded along and across the Eldorado thrust zone at the eastern front of the Lewis and Clark Range and is clearly younger than the thrust.

\section{TERTIARY}

\section{HORNBLENDE MONZONITE}

Hornblende monzonite forms thin dikes and sills, chiefly in the eastern, central, and south-central parts of the area. The typical rock is light gray, fine grained, and equigranular, and is composed of andesine, sanidine, hornblende, augite, biotite, magnetite, and apatite. Abundant small bladelike crystals of hornblende, as much as $5 \mathrm{~mm}$ long, characterize the rock. A chemical analysis is given in column 4 of table 3 .

A dike of hornblende monzonite in the south-central part of the area contains large inclusions of crystalline basement rock of probable early Precambrian age. This is the only intrusion in the Wolf Creek area that contains such inclusions. The dike is about 7 miles $(11 \mathrm{~km})$ long and has a maximum width of about 12 feet $(4 \mathrm{~m})$. The inclusions of basement rock are present throughout the entire length of the dike; they are most abundant and largest within a short segment in the SW1/4 sec. 16 , T. 15 N., R. 4 W. The inclusions consist of subangular to subrounded fragments of granite, granitic gneiss, quartzite, schist, and anorthosite that range from pea-size to large blocks as much as 5 feet $(1.5 \mathrm{~m})$ across. The largest blocks are of granite and granitic gneiss; the inclusions of quartzite, schist, and anorthosite are mostly less than a foot $(30 \mathrm{~cm})$ across. 
The dikes cut thrust faults and folds, were intruded after the deformation that affected the enclosing rocks, and are the youngest bedrock unit in the Wolf Creek area. Their young age is confirmed by a potassium-argon date of 46.3 m.y. (middle Eocene) obtained on hornblende from one of the dikes by $\mathrm{H}$. H. Mehnert (written commun., 1970). This dike is in the south-central part of the area and is the northernmost of two parallel northwesttrending dikes that crop out in secs. 20,28 , and $29, \mathrm{~T} .15 \mathrm{~N}$., R. $4 \mathrm{~W}$. (pl. 1). The dated sample is from the east side of the Stearns-Wolf Creek Road in the northeast corner of sec. 29, T. 15, N., R. 4 W.

\section{MINERAL RESOURCES}

The Wolf Creek area contains insignificant metallic mineral deposits and more promising industrial mineral resources. The metallic mineral deposits consist of small veins bearing copper, silver, and gold, and sedimentary deposits of titaniferous iron ore. The industrial mineral resources include gravel and sand, several types of construction stone, clay and clay shale, bentonite, silica, and coal.

\section{METALLIC-MINERAL DEPOSITS}

\section{VEINS BEARING COPPER, SILVER, AND GOLD}

Small lode deposits of copper, silver, and gold are present in narrow veins in the Greyson Shale, Spokane Formation, and Empire Formation of the Belt Supergroup in the southwest part of the area. These deposits, and two deposits nearby to the south, constitute the Wolf Creek district of the greater Helena mining region described by Pardee and Schrader (1933, p. 108-114). Mining in the district began after the advent of the railroad, about 1890, and was carried on intermittently until 1948 (Sahinen, 1959 , p. 136). During the period 1890-1928, when mining activity was greatest, the district produced about $\$ 40,000$ in copper, $\$ 10,000$ in silver, and an insignificant sum in gold (Pardee and Schrader, 1933, p. 108). Since 1948 , the year in which production was last reported, mining has been limited to a brief period of development at the Rosetta mine (see next page) in 1960 and 1961. Apart from the Rosetta, the old workings in the Wolf Creek district are now largely caved and inaccessible.

The veins containing copper, silver, and gold trend northeast, are steeply dipping, and are widely distributed in the area of Belt rocks. They are generally narrow, tabular, and contain lenslike 
ore shoots that range from less than an inch $(2.5 \mathrm{~cm})$ to a few feet (1-2 $\mathrm{m}$ ) in width. According to Pardee and Schrader (1933, p. 110-114), most of the ore is composed of yellow chalcopyrite [CuFeS ${ }_{2}$ accompanied by yellow pyrite $\left[\mathrm{FeS}_{2}\right]$ in a gangue of white quartz $\left[\mathrm{SiO}_{2}\right]$ and brown barite $\left[\mathrm{BaSO}_{4}\right]$; some of the ore shoots also contain significant amounts of black tennantite $\left[\mathrm{Cu}_{3}(\mathrm{As}, \mathrm{Sb}) \mathrm{S}_{3}\right]$, black tetrahedrite $\left[\mathrm{Cu}_{3}(\mathrm{Sb}, \mathrm{As}) \mathrm{S}_{3}\right]$, blue covellite [CuS], and black tenorite [CuO]; and the ore in a few of the veins is composed of iridescent bornite $\left[\mathrm{Cu}_{5} \mathrm{FeS}_{4}\right]$ and black chalcocite $\left[\mathrm{Cu}_{2} \mathrm{~S}\right]$ in a gangue of quartz and brown ankerite $\left[\mathrm{CaCO}_{3}\right.$. $\left(\mathrm{Mg}, \mathbb{F e}, \mathbb{M}[n) \mathrm{CO}_{3}\right]$. Blue azurite $\left[\mathrm{Cu}_{3}(\mathrm{OH})_{2}\left(\mathrm{CO}_{3}\right)_{2}\right]$ and green malachite $\left[\mathrm{Cu}_{2}(\mathrm{OH})_{2}\left(\mathrm{CO}_{3}\right)\right]$, which are oxidation products of the copper sulfides, are present in most of the veins.

The principal mines and prospects in the district are on Wolf Creek (Rosetta mine), Gladstone Creek, and the Riddle Fork of Little Creek; along the divide between Little Creek and Wolf Creek; in the vicinity of Lanigan Mountain; near the head of Willis Creek; and along Little Creek and Sheep Creek in the ad. jacent Sheep Creek quadrangle. These mines and prospects are brieffy described below.

\section{ROSETTA MINE}

The Rosetta mine, formerly the New $\mathbb{E r a}$ or Rosenfield mine, is on the south side of Wolf Creek near the center of sec. $30, \mathbb{T}$. 15 $\mathbb{N}_{0}, \mathbb{R} .4 W_{0}$, about $41 / 2$ miles $(7.2 \mathrm{~km})$ west of the town of Wolf Creek. The principal working is an adit slightly above stream level that follows a vein southwest for more than 1,000 feet (305 m) (Pardee and Schrader, 1933, p. 111, fig. 20). Two shorter adits are on the hillslope about 240 feet $(73 \mathrm{~m})$ above the main adit. One directly above the main adit was driven several hundred feet (about $100 \mathrm{~m}$ ) southwest, parallel to the vein; the second, a few hundred feet to the southeast, was driven northwest to intersect the vein. On the hillslope near the portal of the second adit is a large dump. The Rosetta vein appears to be localized in a narrow slice of green and red argillite of the Spokane and Empire Formations in the Wolf Creek thrust zone. The ore consists mainly of chalcopyrite and azurite in a gangue of quartz and barite. Pardee and Schrader (1933, p. 110) reported that the mine was operated intermittently from 1922 to 1926 and that smelter net returns for that period showed a production of $\$ 25,516$, chiedly in coppers but including small amounts of silver and gold. The ore ranged from 7 to 25 percent copper, contained $\&$ to 29 ounces, (57 to 
$1,106 \mathrm{~g}$ ) of silver to the ton, and carried 10 cents or less in gold to the ton.

A small amount of development work was carried out at the Rosetta mine in 1960 and 1961. This operation ceased in 1962, presumably because of the lack of marketable ore.

\section{GLADSTONE CREEK}

On Gladstone Creek, a tributary of Wolf Creek, small amounts of copper ore were mined from a northeast-trending vein that runs along the south side of the creek in rocks of the Spokane and Empire Formations. The vein is about $11 / 2$ miles $(2.4 \mathrm{~km})$ long. The mine workings are 1 to 2 miles $(1.6$ to $3.2 \mathrm{~km})$ west of the Rosetta mine in the NW1/4, sec. 25, the SE1/4, sec. 26, and the NW1/4, sec. 35, T. 15 N., R. 5 W., and consist of several short adits driven southeast to intersect the vein. Near the portals are small dumps of waste vein rock carrying minor amounts of pyrite, chalcopyrite, bornite, azurite, and malachite in a gangue of quartz and ankerite. All the workings are now caved and inaccessible.

According to Pardee and Schrader $(1933, p .112)$, one of the adits on Gladstone Creek in the SE $1 / 4$, sec. 26 , known as the Herwood mine, was under development in 1928. The adit was driven 200 feet $(60 \mathrm{~m})$ southeast to intersect the northeast-trending vein, which ranges from an inch $(2.5 \mathrm{~cm})$ to more than a foot $(30 \mathrm{~cm})$ in width. The ore consisted chiefly of bornite, accompanied by small amounts of chalcocite and chalcopyrite, in a gangue of quartz and a little ankerite. A sample shipment of 2,700 pounds $(1,225 \mathrm{~kg})$ of ore from the mine reportedly contained about $\$ 100$ to the ton in copper, silver, and gold.

\section{MIDDLE FORK OF LITTLE GREEK}

A small amount of copper ore was mined on the Middle Fork of Little Creek. The property is on the north side of the creek, about 40 feet $(12 \mathrm{~m})$ above stream level, in the NE1/4 sec. 6, T. $14 \mathrm{~N}$., R. $4 \mathrm{~W}$. The working consists of a short adit driven along a northeast-trending vein. A pile of waste rock at the entrance is mostly iron-stained quartz that contains small amounts of chalcopyrite, azurite, and malachite. The waste pile blocks the entrance, and the adit is filled with water and is inaccessible.

DIVIDE BETWEEN LITTLE CREEK AND WOLF CREEK

On and near the divide between Little Creek and Wolf Creek are a considerable number of prospect pits and adits on northeast- 
trending, copper-bearing quartz-barite veins. These workings are in the NW1/4, sec. 3 and the NW1/4, sec. $4, T$. 14 N., R. 4 W., and in sec. 32, T. 15 N., R. 4 W. The principal mine is in the NW1/4 sec. 4, T. 14 N., R. 4 W., on the Little Creek slope at an altitude of about 4,850 feet $(1,478 \mathrm{~m})$. According to Pardee and Schrader (1933, p. 113-114), the workings in 1928 consisted of two adits, one more than 500 feet $(152 \mathrm{~m})$ long and the second more than 300 feet $(90 \mathrm{~m})$ long. The first adit was driven northeast along a vein a few inches (several centimeters) to as much as 5 feet $(1.5 \mathrm{~m})$ wide in red argillite of the Spokane Formation. Several tons of ore, piled near the entrance, consisted chiefly of barite with some quartz and a little tennantite and chalcopyrite stained with azurite. The second adit, about 110 feet $(34 \mathrm{~m})$ above the first adit, was also driven northeast along the vein. A small stope in this adit was made at one place on an ore shoot 3 to 5 feet ( 1 to $1.5 \mathrm{~m}$ ) wide that contained chalcopyrite, tennantite, galena, and sphalerite. The ore body reportedly contained considerable silver. In 1960, both adits were caved and blocked a short distance from the entrance.

Other workings along the divide between Little Creek and Wolf Creek-a short adit and many prospect pits-were on outcrops of narrow quartz-barite veins stained with azurite, malachite, and limonite. These workings are now thoroughly caved; none appear large enough to have produced ore.

\section{LANIGAN MOUNTAIN}

In the vicinity of Lanigan Mountain, several conspicuous veins cut rocks of the Greyson Shale, Spokane Formation, and Empire Formation. These veins are in the SW1/4, sec. 10 and in sec. 11, T. $15 \mathrm{~N}$., R. $5 \mathrm{~W}$. The veins strike northeast, are steeply dipping, and are as much as 6 feet $(2 \mathrm{~m})$ wide and a mile $(1.6 \mathrm{~km})$ long. Some of the veins consist solely of white quartz, or of white quartz and crushed argillite. Others consist of quartz and considerable barite and contain pyrite, chalcopyrite, and small amounts of bornite that have largely oxidized at the surface to limonite, azurite, and malachite. Prospect pits were sunk along all these veins, some to considerable depth, but apparently little if any ore was ever produced. The pits are now mostly caved; obviously they were worked many years ago.

WILLIS CREEK

At the head of Willis Creek, in the NW1/4 sec. 13, T. $15 \mathrm{~N}$., R. 5 W., are several deep prospect pits that were sunk along a vein 
that cuts red argillite of the Spokane Formation. The vein trends northeast, dips steeply, is as much as a foot $(30 \mathrm{~cm})$ wide, and can be traced for about a quarter of a mile $(0.4 \mathrm{~km})$. The vein consists of quartz and barite accompanied by small amounts of pyrite and chalcopyrite and their oxidation products. Little if any ore was produced.

\section{LITTLE CREEK AND SHEEP CREEK}

Small vein deposits of copper, silver, and gold were mined at two localities in the Sheep Creek quadrangle a short distance south of the Wolf Creek area. One is along both sides of Little Creek about $11 / 2$ miles $(2.4 \mathrm{~km})$ above its junction with Little Prickly Pear Creek, in the northwest corner of sec. 9 and the SW1/4. sec. 3 , T. 14 N., R. 4 . W., roughly 3 miles $(4.8 \mathrm{~km})$ southwest of the town of Wolf Creek. The other locality is on the north side of Sheep Creek about a mile $(1.6 \mathrm{~km})$ above its junction with Little Prickly Pear Creek, in the east half of sec. 14, T. 14 N., R. 4 W., roughly 3 miles $(4.8 \mathrm{~km})$ south of the town of Wolf Creek. These veins and workings were examined by Pardee and Schrader (1933, p. 112-114) in 1928; the descriptions that follow are condensed from their report.

On the south side of Little Creek, the working includes three adits, one near stream level and the other two 100 and 200 feet $(30$ and $60 \mathrm{~m})$ upslope. The two lower adits were caved and inaccessible. The upper adit, about 100 feet $(30 \mathrm{~m})$ long, follows a vein that strikes southwest and dips $45^{\circ} \mathrm{NW}$. The vein is in gray and green argillite of the Greyson Shale, is as much as 4 feet $(1.2 \mathrm{~m})$ wide, and consists of crushed argillite and quartz containing streaks and bunches of bornite and coatings of malachite on seams. The vein can be traced south of the adit for 400 feet $(122 \mathrm{~m})$ or more. From this working, 14 carloads of ore were reportedly shipped, but no record of values is available.

On the north side of Little Creek, an adit 240 feet $(73 \mathrm{~m})$ long intersects a vein that strikes northeast and dips $45^{\circ}-60^{\circ} \mathrm{NW}$. Drifts along the vein aggregate 100 feet $(30 \mathrm{~m})$ or more. The vein is in black argillite of the Greyson Shale, is 4 feet $(1.2 \mathrm{~m})$ wide in places, and consists of sheared argillite and quartz accompanied by copper and iron sulfides. A shipment of 16 tons of ore from this mine gave smelter returns of 10 percent copper, 5 ounces $(142 \mathrm{~g})$ of silver to the ton, and one-hundredth of an ounce $(0.28 \mathrm{~g})$ of gold to the ton. An adit about 150 feet $(46 \mathrm{~m})$ higher on the slope yielded ore that reportedly carried 10 to 20 percent copper, 4 to 20 ounces (113 to $567 \mathrm{~g}$ ) of silver to the ton, and 60 
cents in gold to the ton. Much higher on the slope, a small vein is composed of quartz, chalcopyrite, tennantite, tenorite, and covellite heavily stained with limonite, azurite, and malachite.

At the Sheep Creek locality, two vertical shafts were sunk to a reported depth of 200 feet $(60 \mathrm{~m})$ on a copper prospect. The shafts were opened about 1926, but no ore was discovered, and work had ceased when they were examined by Pardee and Schrader $(1933$, p. 114) in 1928 . The shafts are now largely caved.

\section{SEDIMENTARY DEPOSITS OF TITANIFEROUS IRON ORE}

Deposits of low-grade titaniferous iron ore of sedimentary origin have long been known along the Rocky Mountain front between the Canadian border and Wolf Creek. The ore consists of concentrates of detrital magnetite $\left(\mathrm{Fe}_{3} \mathrm{O}_{4}\right)$ and ilmenite $\left(\mathrm{FeTiO}_{3}\right)$ in beds at the top of the Virgelle Sandstone and the Horsethief Sandstone. The Virgelle ores were sampled by the U.S. Bureau of Mines during World War II near Choteau, Mont., and were found to contain 30.4 to 56.2 percent metallic iron and 3.7 to 8.7 percent titanium oxide (Wimmler, 1946, p. 5-6). Under present metallurgical practices these ores have no commercial value because they cannot compete with ores free of titanium. Eventually, however, they may be of value as a source of both iron and titanium (Sahinen and Crowley, 1959, p. 17).

In the Wolf Creek area, the top of the Virgelle consists of thin beds of dark-brown, dark-reddish-brown, and dark-greenish-gray magnetite-rich sandstone that form a zone 1 to 8 feet $(30 \mathrm{~cm}$ to $2.4 \mathrm{~m}$ ) thick. The magnetite-rich beds are firmly cemented and generally form a prominent ledge. The thickest zone of iron-rich sandstone was observed on the east flank of the prominent ridge known as The Reef in sec. 21, T. 16 N., R. 4 W., near the center of the area. Here, an iron-rich zone is 6 to 8 feet $(1.8$ to $2.4 \mathrm{~m}$ ) thick over a distance of more than a mile $(1.6 \mathrm{~km})$ and consists of several beds of dark-reddish-brown magnetite-rich sandstone as much as 3 feet $(1 \mathrm{~m})$ thick interlayered with thin beds of darkgreenish-gray sandstone in which the concentration of magnetite is leaner. The dark-reddish-brown sandstone consists of small rounded to subangular grains of magnetite, ilmenite, quartz, feldspar, chert, zircon, and sphene (titanite) in a matrix of red hematite, green chlorite, and clay. The magnetite and ilmenite grains make up about 95 percent of the volume of the rock, the other mineral grains about 1 percent, and the cement about 4 percent.

Other localities in the area at which the top of the Virgelle Sandstone is formed of a relatively thick zone of magnetite-rich 
rock are: along Dog Creek, in the east-central part of the area, in sec. 19, T. 16 N., R. 3 W.; along and near the Dearborn River, in the north-central part of the area, in secs. 8, 16, 17, 20, 21, 27, 28, and 34, T. 17 N., R. 4 W.; and along Auchard Creek, in the northwest part of the area, in sec. 12, T. 17 N., R. 5 W.

\section{INDUSTRIAL-MINERAL RESOURCES}

\section{GRAVEL AND SAND}

Large quantities of unconsolidated terrace and alluvial gravel are distributed along the major streams in the area. The deposits are most extensive along the Missouri River, Little Prickly Pear Creek, the Dearborn River, the South Fork of the Dearborn River, Auchard Creek, and Flat Creek. The gravel is made up chiefly of rounded pebbles, cobbles, and boulders of quartzite, quartzitic sandstone, coarse-grained igneous rock, fine-grained volcanic rock (traprock), argillite, siltite, and limestone. The rock constituents are mostly hard, tough, and compact and range in size from fine sand to boulders as much as 3 feet $(1 \mathrm{~m})$ across; the bulk of the gravel, however, consists of cobbles 2 to 3 inches $(5$ to $8 \mathrm{~cm}$ ) long.

The terrace and alluvial gravels were quarried at several localities in and near the area for use as road stone in rebuilding Montana State Highway 287 in the eastern part of the area and in the construction of Interstate Highway $15^{2}$ in the southeastern part. The raw material was used as base course; screened and washed gravel was crushed and used as an upper course and was mixed with asphalt to make the wearing course. The gravel used in the construction of Montana State Highway 287 came principally from terrace deposits above the Dearborn River and from alluvial deposits on the flood plain of the river in the SW1/4 sec. $22, T .17$ N., R. $3 \mathrm{~W}$. The gravel used in the construction of Interstate Highway 15 came principally from terrace deposits above the Missouri River about a mile $(1.6 \mathrm{~km})$ east of the Wolf Creek area in the adjacent Craig quadrangle in the NW1/4, sec. 15, T. 15 N., R. 3 W., and in the NE1/4, sec. $16, T .15 \mathrm{~N}$., R. $3 \mathrm{~W}$. The terrace and alluvial gravels, if washed and screened to the proper size, would probably make excellent concrete aggregate, but extensive tests should be performed before any large-scale use of the material is made for that purpose.

Sand of good quality is not abundant in the Wolf Creek area. Lenses of fine to coarse sand as much as 2 feet $(60 \mathrm{~cm})$ thick,

Interstate Highway 15 is not shown on plate 1 because the base for the plate was made from maps prepared before the highway was bullt. 
made up chiefly of rock fragments and quartz grains, are present in the alluvium that forms the flood plains of the major streams. However, these lenses are difficult to locate and exploit, for the alluvium is ordinarily covered with thick vegetation, and the sand is interlayered with gravel, silt, and clay. Layers and lenses of fine to coarse quartzose sand a few inches (several centimeters) to a foot $(30 \mathrm{~cm})$ thick are found in glacial lake deposits along the Missouri River, Little Prickly Pear Creek, and Rock Creek in the southern part of the area. Considerable exploratory work would be necessary to locate minable sand beds in these deposits too, for they are mostly covered with vegetation and consist largely of silt and clay.

\section{CONSTRUCTION STONE}

Construction stone is classified into two main categories, dimension stone and crushed and broken stone. Dimension stone consists of natural blocks or cut slabs of rock that meet requirements of size and shape for use in building structures such as foundations, walls, floors, walks, terraces, sills, steps, roofs, chimneys, fireplaces, piers, columns, and arches. Crushed and broken stone consists of irregular rock fragments that range in size from large blocks to small granules; the material is quarried for use as riprap, road stone, road dressing, railroad ballast, concrete aggregate, terrazzo, and roofing granules.

A variety of rocks that may be utilized as construction stone are present in the Wolf Creek area. They include welded tuff, latite and trachyte, trachybasalt, quartzitic sandstone and quartzite, argillite and siltite, and limestone.

\section{WELDED TUFF}

Large amounts of welded tuff are present in the ash-flow tuff unit (unit C) of the volcanic member of the western facies of the Two Medicine Formation. This rock is extremely hard, dense, tough, and compact; it can be quarried in large blocks, and it appears to be ideally suited for use as riprap, railroad ballast, and coarse road stone. The Burlington Northern Railway quarries and crushes welded tuff for use as ballast along the tracks between Great Falls and Helena; loose quarry blocks of the rock are used as riprap to retain embankments along the roadbed. The quarry is along the railroad about half a mile $(0.8 \mathrm{~km})$ south of the Wolf Creek area in the adjacent Sheep Creek quadrangle in the SW1/4 sec. 2, T. 14 N., R. 4 W. Large broken blocks of welded tuff from this quarry were used as fill in the approaches to the Interstate 
Highway 15 bridge at the town of Wolf Creek. Blocks of the tuff also were used along this stretch of the highway as riprap to retain the road embankment adjacent to Little Prickly Pear Creek, to line the channel walls of the creek, and to construct baffles in the creek bed to check the flow of water.

Certain properties of the welded tuff suggest that the crushed rock is not suited for use as surfacing stone or unpaved roads or as aggregate in the asphalt or concrete wearing course of paved roads. The base of the welded tuff sheet in the Burlington Northern Railway quarry contains large pods of dense brittle black volcanic glass (obsidian), which, when crushed, breaks into smooth flat and curved fragments with razor-sharp edges. This material would produce extreme wear on tires. Further, the glass fragments do not bond well with asphalt or cement. The welded tuff sheet consists largely of gray, brown, and reddish-brown finely crystalline rocks in which the original glass has recrystallized. When crushed, this rock breaks into sharp-cornered angular fragments that also would probably cause excessive tire wear if used on a road surface. The crushed crystalline tuff might be suitable for use as lower and upper course material in road construction. The bonding and compacting properties of the crushed tuff should be tested and found satisfactory, however, before any extensive use of the material is made for that purpose.

The crystalline welded tuff is extremely resistant to chemical and mechanical breakdown and has a low water content, which suggests that the crushed rock might make excellent concrete aggregate.

Because the welded tuff is irregularly jointed, it breaks into rubble blocks of random size and shape when quarried. Some of these blocks could be used as rough building stone; the rock appears to be unsuitable as dimension stone.

\section{LATITE AND TRACHYTE}

Latite and trachyte form thick lava flows and sills in the volcanic member of the western facies of the Two Medicine Formation. In construction terms, these rocks are traprock. The latite and trachyte are usable as crushed and broken stone, and the latite is also usable as building stone.

The lower parts of the latite and trachyte flows, and the sills, are hard, tough, dense, massive rocks that can be quarried in large blocks and crushed to produce riprap, railroad ballast, and road metal. These rocks are hard but not brittle and, when crushed, break into dull-edged, squarish fragments that should 
have good bonding properties. A large amount of broken and crushed latite was quarried from a roadcut on the Interstate Highway 15 right-of-way in the town of Wolf Creek in 1966. This rock was used as a base course in constructing the foundation of the highway over a 2 -mile $(3.2-\mathrm{km})$ stretch of the road east of the town of Wolf Creek where the subgrade consists largely of soft black shale. Crushed and screened latite and trachyte could probably be used as upper course material and as aggregate in making the asphalt wearing course of roads. Both the latite and trachyte are extremely resistant to chemical and mechanical disintegration, and, when crushed and screened to the proper size, would probably make excellent concrete aggregate.

The latite flow rock possesses jointing that promotes natural breakup of the rock into squared blocks. The rock is fine textured, and the weathered surface is a pleasing brown and brownish gray and is speckled with small white feldspar crystals. Random blocks of the rock have been used locally to construct house walls and a large stone and concrete irrigation dam; the rock should be equally suitable for building retaining walls, steps, and fireplaces. Large quantities of the naturally broken rock have accumulated in talus slides at the base of high east-facing scarps formed by the flows. Some of these slides are readily accessible by truck on ranch roads. The rock could be quarried as rough dimension stone; it is probably not suitable for cut and finished stone.

\section{TRACHYBASALT}

The Adel Mountain Volcanics of Lyons (1944) in the eastern part of the area consist largely of trachybasalt in the form of lava flows, volcanic breccia, volcanic conglomerate, and dikes and sills. These rocks are part of the Adel Mountain Volcanic field that covers about 330 square miles (855 sq. $\mathrm{km}$ ) in Lewis and Clark and Cascade Counties, east of the Wolf Creek area. Trachybasalt flow rock and trachybasalt breccia, which can be classified as traprock, have been used as riprap, road stone, and railway ballast east of the area.

Trachybasalt breccia and flow rock were broken and crushed by blasting and quarried from roadcuts for use in building a 20mile $(32-\mathrm{km})$ stretch of Interstate Highway 15 between Craig and Hardy, where the road crosses the Adel Mountain volcanic field. The crushed and broken rock was used as roadfill and base course material, and large quarry blocks of the rock were used as riprap to retain the road embankment where it borders the Missouri River. Naturally crushed and broken trachybasalt breccia 
also was quarried from a fault zone along Interstate Highway 15 about 2 miles $(3.2 \mathrm{~km})$ southwest of Craig for use as fill and as base course to repair a large break in the highway caused by landslip. The quarry is near the center of sec. 16, T. 15 N., R. 3 $\mathrm{W}$. There, the natural rock is intensively fractured by fault movement, making it relatively easy to quarry. This particular trachybasalt appears to have excellent compacting and bonding properties.

The Great Northern Railway (now part of the Burlington Northern Railway system) at one time used crushed trachybasalt breccia as ballast along the tracks between Great Falls and Helena. The material was quarried a short distance west of the railroad at Hardy, in the northwest corner of sec. 36, T. 17 N., R. 2 W. This quarry, and the use of trachybasalt as ballast, were abandoned by the railway about 20 years ago.

Most of the trachybasalt in the Adel Mountain volcanic field is probably not usable as dimension stone. However, blocks and smaller fragments of the material in some places might serve as rough building stone.

\section{QUARTZITIC SANDSTONE AND QUARTZITE}

Several types of quartzitic sandstone and quartzite in the Wolf Creek area appear to be suitable for construction stone. These are the upper sandstone unit of the Swift Formation, the lower sandstone unit of the Kootenai Formation, the lower sandstone unit of the Flood Member of the Blackleaf Formation, the Flathead Quartzite, and quartzite beds in the Belt Supergroup.

The upper sandstone unit of the Swift Formation is a potential source of dimension stone. This sandstone is evenly bedded in layers that are generally 1 or 2 inches $(2.5$ or $5 \mathrm{~cm})$ thick and breaks down at the surface into flat, squarish slabs that are usable as rough dimension stone. Many of the slabs contain interesting impressions of fossil driftwood. The rock is hard and firmly cemented, is resistant to chemical and mechanical weathering, and is a pleasing brown and yellowish brown. It probably could be quarried and fashioned into rectangular ashlar slabs. In the adjacent Craig quadrangle, artistically fashioned cairns built of natural slabs of Swift sandstone by shepherds in the 1920's and early 1930's attest to the potential of the rock for dry-wall construction. The cairns are built in square, round, and hexagonal shapes, are as much as 8 feet $(2.4 \mathrm{~m})$ high and 5 feet $(1.5 \mathrm{~m})$ wide, and are made of loose, flat, closely fitted slabs set in place with a slight inward tilt. Some of the cairns are hollow. 
The lower sandstone unit of the Kootenai Formation and the lower sandstone unit of the Flood Member of the Blackleaf Formation may be utilized as rough dimension stone and as crushed and broken stone. These rocks are hard, tough, and compact and are composed essentially of grains of quartz and chert bonded firmly in a silica cement. They are extremely resistant to chemical and mechanical breakdown. The Kootenai sandstone is light gray, weathers grayish orange, is medium to coarse grained, and is unevenly bedded in layers several inches (a few centimeters) to several feet (1-2 m) thick. The Flood sandstone is light gray and light greenish gray, weathers brown and dark brown, is fine to medium grained, and is evenly bedded in layers that range from an inch $(2.5 \mathrm{~cm})$ to 1 or 2 feet $(30-60 \mathrm{~cm})$ in thickness.

The Kootenai and Flood sandstones break down naturally into squarish blocks that are widely distributed over the ground near the outcrop. The blocks range from a few inches (several centimeters) to as much as 6 feet $(2 \mathrm{~m})$ across. Many of these natural blocks are usable as rough dimension stone; the larger blocks would make excellent riprap. Both of the sandstones probably could be quarried to obtain rough dimension stone; the Flood sandstone, where thinly layered, might also be suitable for ashlar and flagstone. The hardness and toughness of the Kootenai and Flood sandstones suggest that they might be suitable as crushed stone; screened material might make excellent concrete aggregate.

The Flathead Quartzite has chemical and physical properties that appear to make it suitable for use as dimension stone and crushed and broken stone. It consists almost entirely of quartz grains cemented by overgrowths of clear quartz, and the rock is hard, tough, massive, compact, and extremely resistant to chemical and mechanical weathering. The quartzite in most places is evenly layered; individual beds range from about an inch (2.5 $\mathrm{cm})$ to 1 or 2 feet $(30-60 \mathrm{~cm})$ in thickness. The rock is pale gray, white, and light reddish gray, and the surface weathers to a pleasing tan, brown, or maroon. In places, the quartzite is decoratively streaked by narrow red and purple bands.

The Flathead Quartzite breaks down naturally into large and small squarish blocks that are abundantly spread over the ground near the outcrop; in steep terrain these blocks form large talus slides. Many of the natural blocks appear to be suitable for use as rough dimension stone. The Flathead probably could be quarried to produce crushed and broken stone. The quartzite is the most chemically inert of all the rocks in the Wolf Creek area; crushed material screened to the proper size should make excellent concrete aggregate. 
In two quarries near Neihart, Mont., in Cascade County, tan to maroon, and tan- and maroon-banded, ashlar and flagstone are produced from the Flathead Quartzite (Chelini, 1963, p. 112). Perhaps thinly and evenly layered parts of the Wolf Creek Flathead could likewise be quarried and fashioned into ashlar and flagstone and even into cut and finished stone.

Beds of hard, tough, fine-grained quartzite 1 inch $(2.5 \mathrm{~cm})$ to 3 feet $(1 \mathrm{~m})$ thick are present in the upper part of the Greyson Shale and the middle part of the Spokane Formation. The quartzite in the Greyson is pale gray and pale greenish gray; that in the Spokane is gray and grayish red. Although this quartzite is thinly layered, it does not split well and is difficult to fashion into slabs. Quartzite beds an inch $(2.5 \mathrm{~cm})$ or so thick, however, probably could be quarried in slabs for use as rough building stone.

ARGILLITE AND SILTITE

The Greyson Shale, Spokane Formation, and the Empire Formation consist largely of thin layers of argillite and siltite that range through shades of gray, green, brown, red, and purple. Rocks of this type, which crop out extensively over much of northwestern Montana and which bear some resemblance to slate, are usable both as building stone and as crushed and broken stone.

Much of the argillite and siltite is hard and tough and thinly laminated and breaks down naturally into loose squarish blocks and flat slabs that have been widely utilized as building stone. The rock has been used principally as rough ashlar and flagstone to build structures such as walls, walks, patios, floors, terraces, terrace facings, and garden borders. In a few places, hand-trimmed slabs of the rock have been used as exterior wainscotting on houses. The argillite and siltite can be easily quarried, and some of the hard, tough, evenly and thinly laminated rock should be suitable for commercial ashlar and flagstone and cut and finished stone.

Argillite and siltite were quarried in roadcuts and used as fill to build the foundation of the 25-mile $(40-\mathrm{km})$ stretch of Interstate Highway 15 between Helena Valley and Wolf Creek in the years 1961 to 1964 . Where the highway runs through the canyon of Little Prickly Pear Creek, large massive blocks of the material were used as riprap to retain the road embankment adjacent to the creek and to construct baffles in the creek bed. Red and green argillite and siltite of the Spokane Formation also were crushed and screened for use as upper course material and as aggregate in making the asphalt wearing course of the highway between 
Helena Valley and Wolf Creek. The crushed and broken argillite and siltite appear to have excellent compacting, binding, wearing, and draining properties, for the roadbed and the original wearing course on this part of the highway have withstood more than 12 years of use without developing any serious flaws.

Green and red argillite and some quartzite of the Belt Supergroup are quarried and crushed by the Burlington Northern Railway for use as ballast along the mainline tracks in northern Montana. The quarry is along the Middle Fork of the Flathead River, about 15 miles $(24 \mathrm{~km})$ west of Marias Pass, in Flathead County. Similar rocks in the Wolf Creek area, and in adjacent areas to the west and south, are also a potential source of stone for this purpose.

\section{LIMESTONE}

Limestone, which is quarried extensively in Montana and other States to produce construction stone, smelter flux, portland cement, and lime, is not abundant in the area.

Limekiln Mountain and Painted Hill, in the west-central part of the area, are capped by small masses of Meagher Limestone, much of which is massive, compact, and probably fairly pure calcium carbonate. The name Limekiln Mountain suggests that this rock was burned to obtain lime, but there is no other evidence of such use. Somewhat larger masses of Meagher Limestone crop out along the North Fork of Little Creek and along Wolf Creek in the southwestern part of the area. Broken and crushed Meagher Limestone would probably make excellent road metal and concrete aggregate, but the deposits are too small and too inaccessible to be of much value.

Blocks and masses of Mission Canyon and Lodgepole Limestones along the Eldorado thrust fault in the southwestern part of the area are too small for commercial exploitation but could be used locally as a source of lime. A large block of Mission Canyon Limestone in the thrust zone along the present Recreation Road (former U.S. Highway 91) about 2 miles $(3.3 \mathrm{~km})$ south of the town of Wolf Creek, in the adjoining Sheep Creek quadrangle, was used as a local source of lime by early settlers. The ruins of the brick kiln used to burn this limestone are at the mouth of Sheep Creek, about a quarter of a mile $(0.4 \mathrm{~km})$ south of the limestone exposure.

Limestone in the Kootenai, Morrison, and Sawtooth Formations is too shaly and (or) sandy for use as construction stone or as a source of lime. The Helena Dolomite, which crops out along the 
summit and flanks of Rogers Mountain, contains some fairly pure dolomitic limestone that might be suitable for the manufacture of high-magnesium lime, but it is not easily accessible. The great bulk of the Helena Dolomite contains large amounts of shaly and siliceous impurities; this formation has not been quarried commercially as a source of lime.

\section{GLAY AND GLAY SHALE}

Clay and clay shale (indurated clay) are used in the manufacture of brick, tile, pottery, stoneware, and lightweight concrete aggregate. Large amounts of clay and clay shale are present in the area, but their suitability for local or commercial use is not known. Before any large-scale development, a detailed investigation of the extent of the deposits and thorough tests of the material should be made.

The only soft clay that might be suitable for ceramics or lightweight aggregate is found in glacial lake deposits along the Missouri River, Little Prickly Pear Creek, and Rock Creek in the southwestern part of the area. In places, these lake deposits contain sequences of dark- and light-brown clay layers as much as several feet (1-2 m) thick. The clays are soft and plastic when wet. The ceramic and bloating properties of four samples of clay from lake deposits of equivalent age in and near Great Falls have been tested (Sahinen and others, 1958, p. 20-21). All the samples proved to be unsatisfactory as possible ceramic raw materials because of their high content of montmorillonite clay. However, two of the samples were found to be suitable for expanded lightweight aggregate. The composition of the glacial lake clays in the Wolf Creek area might be considerably different from the composition of the clays near Great Falls, inasmuch as these widely separated deposits were probably derived from different source areas. Hence, the tests of the Great Falls samples do not necessarily apply to the Wolf Creek clays. Banded clay derived from similar deposits near Missoula, Mont., was formerly used in the commercial manufacture of brick (Sahinen and others, 1958, p. 9).

On the basis of comparison with material elsewhere in Montana, certain clay shales in the Two Medicine and Kootenai Formations, and argillite of the Belt Supergroup, may be suitable for the manufacture of brick. These rocks require grinding and would have to be thoroughly tested before any large-scale use of the material was made for this purpose. Soft gray shale from the Judith River Formation was formerly used for the manufacture 
of common and face brick in Havre (Sahinen and others, 1958, p. 4, 19). Large amounts of shale, similar in appearance and of the same geological age, are present in the middle part of the eastern facies of the Two Medicine Formation in the eastern part of the Wolf Creek area. A red clay from the Kootenai Formation at Lewiston is made into common and face brick (Sahinen and others, 1958, p. 16). This material does not require grinding before use. Red clay shale of similar composition, but more compact and consequently much harder than the material used at Lewiston, and requiring at least some grinding, is found in the lower part of the Kootenai Formation in the southeastern part of the Wolf Creek area. Samples of pinkish-gray, red-weathered, medium-hard, laminated argillite and hard, black, gray-weathered argillite from the Greyson Formation near Whitehall were found to be suitable for making common brick (Sahinen and others, 1958, p. $4,15,16)$. Both these rocks require considerable grinding before use. The pinkish-gray, red-weathered shale was used at the old brick plant in Butte to make common and face brick. Large amounts of red argillite in the Spokane Formation and black and gray argillite in the lower part of the Greyson Shale in the southwestern part of the Wolf Creek area are similar to the rocks near Whitehall.

Certain clays and shales in Montana are suitable for the production of light-weight aggregate for concrete (Nelson, 1947; Sahinen, 1957; Sahinen and others, 1958; Sahinen, 1963). These rocks have a high content of montmorillonite and expand to a firm cellular product when heated suddenly to a temperature near the fusion point. Near Great Falls, montmorillonitic (bentonitic) shale from the Taft Hill Member of the Blackleaf Formation is used to produce light-weight aggregate (Sahinen, 1963, p. 62). The Taft Hill Member crops out widely in the southeastern part of the Wolf Creek area and probably contains shale that may also be suited for making light-weight aggregate. Other shales in the Wolf Creek area that are potentially usable for this purpose are: gray and green bentonitic shale in the Vaughn Member of the Blackleaf Formation; gray and black shale in the Floweree Shale, Ferdig, and Kevin Members of the Marias River Shale; and gray and green bentonitic shale in the lower and middle parts of the eastern facies of the Two Medicine Formation.

\section{BENTONITE}

Bentonite is a natural clay material, formed from the altera- 
tion of glassy volcanic ash, that consists essentially of the clay minerals montmorillonite and beidellite. Some bentonite swells greatly when wetted; this property has led to extensive use of the material as a sealant for irrigation canals, earthen dams, and reservoirs. Bentonite of the proper quality is also used in the preparation of rotary drilling mud, as a bonding agent in the preparation of foundry molding sands, and for pelletizing lowgrade iron ore. Other uses of bentonite are as a filler, a thickening agent, and a suspender in the manufacture of paper, paint, adhesives, insecticides, fungicides, printing inks, and pharmaceuticals. Berg (1969) has discussed the occurrance, properties, and uses of bentonite in Montana.

In the Wolf Creek area, beds of bentonite are present in the Vaughn Member of the Blackleaf Formation; in the Floweree, Cone, Ferdig, and Kevin Members of the Marias River Shale; and in the eastern and western facies of the Two Medicine Formation. Most, if not all, of these beds are too thin and have too much overburden to be of commercial value. Some of the beds, however, are as much as 3 feet $(1 \mathrm{~m})$ thick; these probably could be mined for local use to seal irrigation canals, earthen dams, and reservoirs against leakage.

A bed of bentonite a few inches (several centimeters) to as much as 3 feet $(1 \mathrm{~m})$ thick is present near the base of the Cone Member of the Marias River Shale. This bentonite is yellowish orange, contains scattered flakes of green chlorite, and in places contains thin seams and veinlets of calcite. The swelling properties of the Cone bentonite are unknown, but it is probably suitable as a sealant.

A bed of pale-green bentonite, as much as 3 feet $(1 \mathrm{~m})$ thick, is present locally about 100 feet $(30 \mathrm{~m})$ above the base of unit $D$ in the volcanic member of the western facies of the Two Medicine Formation in the southwestern part of the area (pl. 1). The bed extends about 1 mile $(1.6 \mathrm{~km})$, from the northwest corner of sec. 27, T. 15 N., R. 4 W. into the south half of sec. 22 , T. 15 N., R. 4 W. This bentonite appears to be pure; the surface exposures have a popcornlike texture, indicating that the material has good swelling properties and might make an excellent sealant. Unfortunately, the bed dips $10^{\circ}$ to $12^{\circ} \mathrm{W}$., so that the thick overburden probably would prevent commercial exploitation.

Several beds of pale-green bentonite, generally less than a foot $(30 \mathrm{~cm})$ thick but in places as much as 3 feet $(1 \mathrm{~m})$ thick, are present in the eastern facies of the Two Medicine Formation 650 to 1,450 feet (198 to $442 \mathrm{~m}$ ) above its base. Even the thickest of 
these beds are, however, difficult to exploit, for they are mostly covered with vegetation and are thus hard to recognize and trace, and are steeply dipping and difficult to mine efficiently.

Many beds of light-gray and pale-yellowish-green bentonite a few inches (several centimeters) to as much as 2 feet $(60 \mathrm{~cm})$ thick are present in the Vaughn Member of the Blackleaf Formation. The Vaughn bentonite is generally somewhat silty and may be nonswelling. The beds are also steeply dipping and thus are difficult to mine. Northeast of the Wolf Creek area, in the vicinity of Cascade, Ulm, and Great Falls, the bentonite of the Vaughn is reported to be of poor quality (Maughan, 1961; Fox, 1966).

Beds of light-gray, yellowish-gray, and yellowish-orange bentonite as much as a foot thick are found near the middle of the Floweree Shale Member of the Marias River Shale, at the base of the Ferdig Member of the Marias River Shale, in the lower and upper parts of the Kevin Member of the Marias River Shale, in the lower part of the sedimentary member of the western facies of the Two Medicine Formation, and near the base of the eastern facies of the Two Medicine. All of these beds are probably too thin to be of economic value.

\section{SILICA}

Silica $\left(\mathrm{SiO}_{2}\right)$ in the form of quartz sand is the principal ingredient in the manufacture of glass. Large amounts of silica are also used for metallurgical flux, refractories, molding sand, engine sand, hydrafrac sand, and sandblasting. Very high grade silica is the source of metallic silicon, used in the manufacture of semiconductors and silicones.

Some of the Flathead Quartzite in the southwestern part of the area may be a potential source of silica. Locally, the Flathead contains beds of pure, pale-gray to white, fine- to medium-grained quartzite as much as several feet (1-2 m) thick. These beds are composed of small grains of quartz cemented with overgrowths of clear quartz, and the rock appears to be nearly free of iron oxide or other impurities. This material might meet the specifications for glass sand (less than 0.06 weight percent of iron). Most of the Flathead is composed of quartzite that contains some impurities and in which the constituent grains of quartz are coated with films of red iron oxide. This rock is estimated to consist, however, of 95 to 98 percent quartz; thus, it may be suitable for such uses as metallurgical flux, refractory lining, and molding sand. It is also suitable for engine sand and for sandblasting, as the material used for these purposes need not be especially pure. The Flathead 
Quartzite is hard, compact, and dense and does not break down naturally into loose sand particles. The rock would therefore require crushing and grinding before it could be used for any of the above purposes. The Flathead probably does not contain any quartzite pure enough to serve as raw material for the production of silicon metal.

A vein of milky quartz that crosses Lanigan Mountain in the NW1/4, sec. 11 and the SE1/4, sec. 10, T. 15 N., R. 5 W., in the southwestern part of the area, may constitute a potential source of silica. This vein is slightly more than a mile $(1.6 \mathrm{~km})$ long and is as much as 6 feet $(2 \mathrm{~m})$ wide. It commonly stands several feet (1-2 $\mathrm{m}$ ) above the surrounding ground surface. The vein consists largely of dense white to creamy-white quartz and is devoid of barite or disseminated sulfide minerals that are present in most of the other veins in the area. In places, the borders of the vein contain many crushed fragments of green and red argillite derived from the enclosing rocks. Crushed and ground quartz from this vein would probably be suitable for use as metallurgical flux, refractory lining, molding sand, engine sand, and for sandblasting. If freed of argillic impurities, the material might meet the requirements for glass sand. The vein quartz is probably not pure enough to constitute a source of metallic silicon.

\section{COAL}

Coal is not abundant in the Wolf Creek area. Thin beds of lignite and low-rank coal in the lower 130 feet $(40 \mathrm{~m})$ of the eastern and western facies of the Two Medicine Formation are interlayered with sandstone, siltstone, mudstone, and bentonite. Generally there are four or five carbonaceous beds in this interval, and locally, as many as 10 . The carbonaceous beds are ordinarily a few inches (several centimeters) to 1 or 2 feet $(30-60 \mathrm{~cm}$ ) thick, but in some places they are as much as 6 feet $(2 \mathrm{~m})$ thick. They are lenticular and rarely extend more than a few hundred feet $(100-200 \mathrm{~m})$ along strike. At several places, lignite and coal were obtained from the Two Medicine Formation by early residents. Their workings are now caved and abandoned. The principal localities where coal was mined are briefly described below.

A considerable amount of low-rank coal was obtained just south of the town of Wolf Creek. The principal workings, consisting of 10 or more small pits and at least one adit, are in the NE1/4 sec. 2, T. 14 N., R. $4 \mathrm{~W}$. The coal was mined from four beds in the lower 65 feet $(20 \mathrm{~m})$ of the sedimentary member of the western facies of the Two Medicine Formation. These coal beds range from 
$11 / 2$ to 6 feet $(45 \mathrm{~cm}$ to $2 \mathrm{~m})$ in thickness and contain thin beds of yellowish-orange bentonite. Many of the coal fragments in waste piles near the old workings are black and hard and are probably of subbituminous or bituminous grade.

A small amount of coal was mined about three-quarters of a mile $(1.2 \mathrm{~km})$ northeast of the Nohrgang Ranch at the southeast corner of sec. 31 , T. 16 N., R. 3 W., in the east-central part of the area. The workings consist of a small pit and waste pile. The coal was obtained from a 2-foot-thick (60-cm-thick) bed in the lower part of the eastern facies of the Two Medicine Formation. The coal has a brownish cast and is probably lignite.

A large volume of coal was obtained at two localities along the Dearborn River, about 3 miles $(4.8 \mathrm{~km})$ northwest of the Dearborn Ranch, in the north-central part of the area. One is in the NW1/4,SE1/4,SE1/4, sec. 21, T. 17 N., R. 4 W., in the bluffs on the west side of the river; the other is in the NE1/4, SE1/4, NE1/4 sec. 21, T. 17 N., R. 4 W., in the bluffs on the east side of the river. At the first locality, good-quality coal was obtained from a bed about 10 feet $(3 \mathrm{~m})$ above the base of the eastern facies of the Two Medicine Formation. The coal bed is 4 to 5 feet $(1.2$ to $1.5 \mathrm{~m})$ thick, dips steeply to the west, and crops out in a narrow band that can be traced for several hundred feet $(100-200 \mathrm{~m})$. The bed contains partings of olive-gray claystone and bentonite. The coal was mined by trenching and also from an adit driven into the hillside parallel to the strike of the bed about 20 feet $(6 \mathrm{~m})$ above the river. The adit is now caved. The coal in a large waste pile near the portal is hard, dense, and black and is the best quality coal observed by this writer in the area. It is probably of subbituminous or bituminous rank. At the second locality, in the bluffs on the east side of the Dearborn River, coal was mined from several closely spaced beds in the lower part of the eastern facies of the Two Medicine Formation. The beds there are locally as much as 5 feet $(1.5 \mathrm{~m})$ thick and were mined by shallow trenching over a strike length of about 200 feet $(60 \mathrm{~m})$. Most of this coal has a brownish cast and is probably lignite.

A small amount of coal was obtained at two localities about half a mile $(0.8 \mathrm{~km})$ east and southeast of Black Rock in the north-central part of the area. These localities are in the NW1/4 NE $1 / 4, \mathrm{SW}^{1} / 4$, and the SE $1 / 4, \mathrm{NW}_{1} / 4 \mathrm{NW}^{1} / 4$, sec. 8 , T. 17 N., R. 4 W. At both places, the coal was mined by trenching from thin beds in the lower part of the eastern facies of the Two Medicine Formation. Small waste piles remain in the vicinity of the workings. The coal is brownish black and is probably lignite. 


\section{REFERENCES CITED}

Alden, W. C., 1932, Physiography and glacial geology of eastern Montana and adjacent areas: U.S. Geol. Survey Prof. Paper 174, 133 p.

Barksdale, J. D., 1951, Cretaceous glassy welded tuffs, Lewis and Clark County, Montana: Am. Jour. Sci., v. 249, no. 6, p. 439-443.

Barnett, V. H., 1916, Geology of the Hound Creek district of the Great Falls coal field, Cascade County, Montana: U.S. Geol. Survey Bull. 641-H, p. 215-231.

Berg, R. B., 1969, Bentonite in Montana: Montana Bur. Mines and Geology Bull. 74, 34 p.

Boyd, F. R., 1961, Welded tuffs and flows in the rhyolite plateau of Yellowstone Park, Wyoming: Geol. Soc. America Bull., v. 72, no. 3, p. 387-426.

Calhoun, F. H. H., 1906, The Montana lobe of the Keewatin ice sheet: U.S. Geol. Survey Prof. Paper 50, 62 p.

Chelini, J. M., 1963, Metallic and industrial mineral resources-Stone, in Mineral and water resources of Montana: U.S. Cong., 88th, 1st sess., Comm. Print, p. 111-112.

Cobban, W. A., 1945, Marine Jurassic formations of Sweetgrass arch, Montana: Am. Assoc. Petroleum Geologists Bull., v. 29, no. 9, p. 1262-1303.

Cobban, W. A., Erdmann, C. E., Lemke, R. W., and Maughan, E. K., 1959, Revision of Colorado Group on Sweetgrass arch, Montana: Am. Assoc. Petroleum Geologists Bull., v. 43, no. 12, p. 2786-2796.

1976, Type sections and stratigraphy of the members of the Blackleaf and Marias River Formations (Cretaceous) of the Sweetgrass arch, Montana: U.S. Geol. Survey Prof. Paper 974, 66 p.

Erdmann, C. E., Gist, J. T., Nordquist, J. W., and Beer, G. W., 1947, Map of the areal and structural geology of T. 35 N., R. 3 W., Toole County, Montana, showing oil pools in West Kevin district, Kevin-Sunburst oil field: U.S. Geol. Survey Gen. Mineral Resource Map, 2 sheets.

Fox, R. D., 1966, Geology and ground-water resources of the Cascade-Ulm area, Montana: Montana Bur. Mines and Geology Bull. 52, $64 \mathrm{p}$.

Gill, J. R., and Cobban, W. A., 1966, The Red Bird section of the Upper Cretaceous Pierre Shale in Wyoming: U.S. Geol. Survey Prof. Paper 393-A, 73 p.

Harrison, J. E., and Campbell, A. B., 1963, Correlations and problems in Belt Series stratigraphy, northern Idaho and western Montana: Geol. Soc. America Bull., v. 74, no. 12, p. 1413-1428.

Klepper, M. R., Robinson, G. D., and Smedes, H. W., 1971, On the nature of the Boulder batholith of Montana: Geol. Soc. America Bull., v. 82, no. 6, p. $1563-1580$.

Klepper, M. R., Weeks, R. A., and Ruppel, E. T., 1957, Geology of the southern Elkhorn Mountains, Jefferson and Broadwater Counties, Montana: U.S. Geol. Survey Prof. Paper 292, 82 p.

Knopf, Adolph, 1957, The Boulder bathylith of Montana: Am. Jour. Sci., v. 255, no. 2, p. 81-103.

Larsen, E. S., Jr., 1940, Petrographic province of central Montana: Geol. Soc. America Bull., v. 51, no. 6, p. 887-948.

Lyons, J. B., 1944, Igneous rocks of the northern Big Belt Range, Montana: Geol. Soc. America Bull., v. 55, no. 4, p. 445-472. 
Maughan, E. K., 1961, Geology of the Vaughn quadrangle, Montana: U.S. Geol. Survey Geol. Quad. Map GQ-135.

Mudge, M. R., 1966a, Geologic map of the Patricks Basin quadrangle, Teton and Lewis and Clark Counties, Montana: U.S. Geol. Survey Geol. Quad. Map GQ-453.

1966b, Geologic map of the Pretty Prairie quadrangle, Lewis and Clark County, Montana: U.S. Geol. Survey Geol. Quad. Map GQ-454.

1966c, Geologic map of the Glenn Creek quadrangle, Lewis and Clark and Teton Counties, Montana: U.S. Geol. Survey Geol. Quad. Map GQ499.

1967, Geologic map of the Arsenic Peak quadrangle, Teton and Lewis and Clark Counties, Montana: U.S. Geol. Survey Geol. Quad. Map GQ-597.

1972, Pre-Quaternary rocks in the Sun River Canyon area, northwestern Montana: U.S. Geol. Survey Prof. Paper 663-A, 142 p.

Nelson, H. E., 1947, Light-weight aggregate for concrete from Montana shales: Butte, Mont., Montana School Mines, unpub. M.S. thesis.

Pardee, J. T., and Schrader, F. C., 1933, Metalliferous deposits of the Greater Helena mining region, Montana: U.S. Geol. Survey Bull. 842, $318 \mathrm{p}$.

Rezak, Richard, 1957, Stromatolites of the Belt series in Glacier National Park and vicinity, Montana: U.S. Geol. Survey Prof. Paper 294-D, p. 127-154.

Roberts, A. E., 1965, Correlation of Cretaceous and lower Tertiary rocks near Livingston, Montana, with those in other areas of Montana and Wyoming: U.S. Geol. Survey Prof. Paper 525-B, p. B54-B63.

Robinson, G. D., Klepper, M. R., and Obradovich, J. D., 1968, Overlapping plutonism, volcanism, and tectonism in the Boulder batholith region, western Montana, in Studies in volcanology-A memoir in honor of Howel Williams: Geol. Soc. America Mem. 116, p. 557-576.

Robinson, G. D., and Marvin, R. F., 1967, Upper Cretaceous volcanic glass from western Montana: Geol. Soc. America Bull., v. 78, no. 5, p. 601-608.

Sahinen, U. M., 1957, Expandable shale in the Great Falls area, Montana: Montana Bur. Mines and Geology Inf. Circ. 18, 14 p.

1959, Metalliferous deposits in the Helena area, Montana, in Billings Geol. Soc., Guidebook 10th Ann. Field Conf., 1959: p. 129-140.

1963, Metallic and industrial mineral resources-Clays, in Mineral and water resources of Montana: U.S. Cong., 88th, 1st sess., Comm. Print, p. 60-62. 
Sahinen, U. M., and Crowley, F. A., 1959, Summary of Montana mineral resources: Montana Bur. Mines and Geology Bull. 11, 51 p.

Sahinen, U. M., Smith, R. I., and Lawson, D. C., 1958, Progress report on clays of Montana: Montana Bur. Mines and Geology Inf. Circ. 23, 41 p.

Schmidt, R. G., 1963, Preliminary geologic map and sections of the Hogan 4 Southeast [Wolf Creek] quadrangle, Lewis and Clark County, Montana: U.S. Geol. Survey Misc. Geol. Inv. Map I-379.

1966, Preliminary geologic map of the Comb Rock quadrangle, Lewis and Clark County, Montana: U.S. Geol. Survey Misc. Geol. Inv. Map I-468.

1972a, Geologic map of the Wolf Creek quadrangle, Lewis and Clark County, Montana: U.S. Geol. Survey Geol. Quad. Map GQ-974.

1972b, Geologic map of the Coburn Mountain quadrangle, Lewis and Clark and Cascade Counties, Montana: U.S. Geol. Survey Geol. Quad. Map GQ-975.

1972c, Geologic map of Comb Rock quadrangle, Lewis and Clark County, Montana: U.S. Geol. Survey Geol. Quad. Map GQ-976.

Schmidt, R. G., and Strong, C. P., Jr., 1968, Preliminary geologic map of the Roberts Mountain quadrangle, Lewis and Clark County, Montana: U.S. Geol. Survey Misc. Geol. Inv. Map I-564.

1972, Geologic map of the Roberts Mountain quadrangle, Lewis and Clark County, Montana: U.S. Geol. Survey Geol. Quad. Map GQ-977.

Schmidt, R. G., Swanson, D. A., and Zubovic, Peter, 1964, Preliminary geologic map and sections of the Hogan 4 Northeast [Coburn Mountain] quadrangle, Lewis and Clark and Cascade Counties, Montana: U.S. Geol. Survey Misc. Geol. Inv. Map I-409.

Tilling, R. I., Klepper, M. R., and Obradovich, J. D., 1968, K-Ar ages and time span of emplacement of the Boulder batholith, Montana: Am. Jour. Sci., v. 266, no. 8, p. 671-689.

Tozer, E. T., 1956, Uppermost Cretaceous and Paleocene non-marine molluscan faunas of western Alberta: Canada Geol. Survey Mem. 280, 125 p.

U.S. Geological Survey, 1971, Montana disturbed belt-Dating the Eldorado thrust: U.S. Geol. Survey Prof. Paper 750-A, p. A37.

Viele, G. W., and Harris, F. G., III, 1965, Montana Group stratigraphy, Lewis and Clark County, Montana: Am. Assoc. Petroleum Geologists Bull., v. 49 , no. 4 , p. $379-417$.

Wimmler, N. L., 1946, Exploration of Choteau titaniferous magnetite deposit, Teton County, Montana: U.S. Bur. Mines Rept. Inv. 3981, 12 p. 



\section{INDEX}

[Italic page numbers indicate major references]

A

Absaroka Range

Actinocrinitid plate -. Adel Mountain Volcanics of Lyons (1944)

Age, volcanic member of Two Medicine Formation -Adel Mountain Volcanics of Lyons (1944)

Alluvium _Analcime-bearing augite trachybasalt Analcime gabbro

Andesite $33,34,38,39$, Anomin

micronema subquadrata sp

Aporrhais meeki

Arches

Argillite, as construction stone Ash-fall tuff

Ash-flow tuffs, unit in volcanic member of Two Medicine Formation 33,35 sheets Formation

Ashlar slabs Asphalt wearing course _... 69, 71, 72, 75 Astarte sp

Augite andesite _..._. 32,40

Augite trachyandesite

Augite trachybasalt _... 49, 58

\section{B}

Baculites asper
codyensis
cuneatus
mariasensis
obtusus
sweetgrassensi.s
sp

Base course material, roads _.....

Bearpaw Mountains

Bearpaw Shale

Belemnites

Belt Supergroul,

Bentonite, as industrial mineral resource

bonding agent

filler

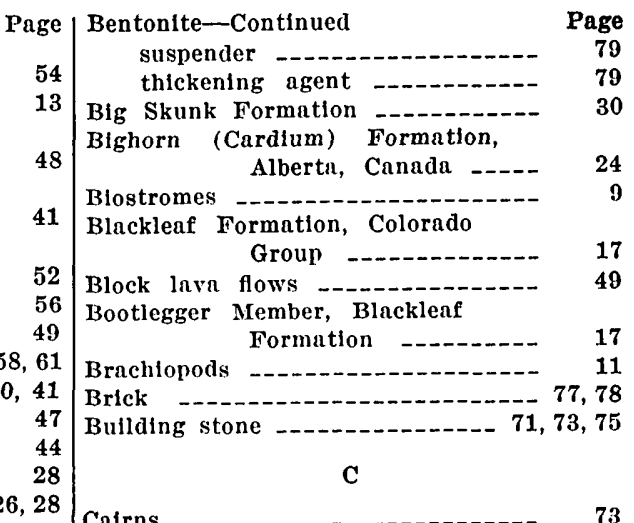

Cairns -

Camptonectes sp _..._... 14

Canals, irrigation -... 75

Cardium pauperculum _._._._._-_ 24

sp

Casts, mud-crack

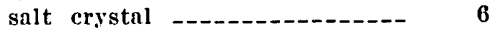

Cephalopods _._._._. 22, 25, 26, 28, 42

Ceramic raw materials _._-_._-_.-- 77

Ceramics -

Chimneys _._.

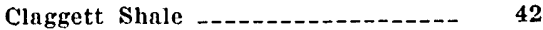

Clappaspis -

Clastic volcanic rocks, unit in volcanic member of 'Two Medicine

Formation - 33, 35, 37, 39, 40

Clay, as industrial minernl resource $\mathbf{7 7}$

Clay shale, as industrial mineral resource - 77

Clioscaphites novimexicanus _..- 28 saxitonianus vermiformis -... 28,42 sp - 28

Coal, as industrial mineral resource $-81,82$ Collenia -_......... 9

Colluvial deposits -

Colorado Group -

Columns _....... 70

5,6 Concrete aggregate $76,77,78$

78 Concrete wearing course

79 Concretions : calcareous $46,48,55$ 
Concretions-Continued

calcareous claystone _._.

calcareous sandstone $-16,19,24,29$,

31,44

ferruginous - _..._.

ironstone -

limestone _................ 22, 25

Cone Member, Marias River Shale --

Construction stone --_-_-_---

arglllite and siltite

latite and trachyte

limestone

quartzitic sandstone and quartzite

trachybasalt

Copper

lded tuff

Coquinoid limestone

Corbula

subtrigonalis

Correlation, Adel Mountain Volcanics of Lyons (1944)

voleanic member of Two Medicine Formation --

Craig anticlinorium

Crassatella wyomingensis ......-

sp -

Crassostrea wyomingensis _.......

Cretaceous System

Cretaceous and Tertiary Systems -..

Crinoid

18
21

21
70

$\mathbf{7 0}$

Ferdig Member, Marias River Shale -

Fireplaces

Ehmania -

Elkhorn Mountains Volcanics -...--

Page

Empire Formation, Belt Supergroup 8

Eutrephoceras sp _.

Flngstone

Flatheal Quartzite

Flood Member, Blackleaf Formation 17

Floors _._.

Flow breccia -

Crinoidal debris -.._-_._- 13

Crossbedded, crossbedding _- $6,7,8,10,16$, $19,27,29,31,34$, $37,39,41,44,45$, 46,48

Crushed and broken stone $--70,71,74,75$ Cut and finished stone Cymbophora arenaria

sp

D

Dam, irrigation

earthen

Diagenetic alteration, Vaughn Member of Blackleaf Formation -........

Dictyonina -
Dikes : inalcime gabbro _........-. hornblende monzonite ......... rhyolite

trachybasalt

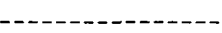

Dimension stone -_._- 70, 71, 72, 73, 74

Dinosaur bone fragments _-_._._. 45

Diorite

Driftwood _._._. 15, 73

Dry Creek syncline

$\mathbf{E}$

Eagle Sandstone

30,42

Eastern facies, Two Medicine

Formation

Edgewise conglomerate

Echinodermal debris

\section{Fossiliferous mudstone -_-_._- 31,46}

Fossilized wood _.

Foundations -

Foundry molding sand

Gabbro _-

Gangue -

ankerite - -

barite _.............. 64, 66, 67

limonite _... quartz _........ $64,65,66,67,68$

Garden borders _... 75

Gastropods _..._.

Glacial lake deposits _... 55

Glacial Lake Great Falls _._._._. 55

Glacial varves _._._. 55

Glass sand -

Gold _._.

Graded bedding _._._._._._._._. 10

Gravel, as industrial mineral
resource

Greyson Shale, Belt Supergroup - 6

Gyrodes Aepressa -

sp _... 28

H

Helena Dolomite, Belt. Supergroup -- 8

Herwood mine _..._. 65

High-magnesium lime _._-_._. 77

Highwood Mountains _..._._._. 54

Hornblende indesite _._._.

43 Hornblende monzonite _._.____._ 58,62

9 Horsethief Sindstone - 68

13 Hydrafrac sand _- 
Page

Ichthyodectes

Inclusions, Precambrian basement rock

Industrial mineral resources -.... bentonite clay and clay shale -......... coul -...--construction stone gravel and sand --.----.-sillica

Inoceramus cardissoides cordiformis deformis

koeneni

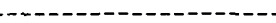

lundbreckensis _........... 28,

pontoni _........--

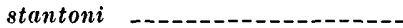
tuberculatus

Lignite, as industrial mineral

Page

Intrusive rocks

analcime gabbro

diorite

hornblente

latite -

quartz monzonite porphyry -. rhyodacite porphyry

rhyolite

trachybasalt

trachyte

Iron ore, titaniferous

J

Judith River Formation

Jurassic System

\section{$\mathbf{K}$}

Kevin Member, Marias River Shale -

Klippe, klippen Kootenal Formation

\section{L}

Lacustrine deposits, unit in Adel Mountain Volcanics of Lyons (1944) _...--

randslide deposits _....... Lapilli tuff

Latite:

construction stone

Hows unit in voleanic member of Two Medicine

Formation _...- $32,33,34$

fragments _...- $34,38,40,49,51,52$

intrusive

Leaf impressions _... 18, 51

Legumen ellipticum _._._._._- 24

Lightweight aggregate _._._._._ 77, 78

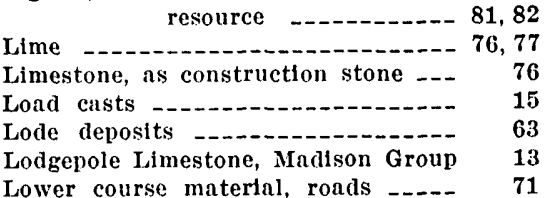

\section{M}

MacGowan Concretionary bed _... 25

Madison Group _..... 13

Marias River Shale, Colorado Groun 21

Meagher Iimestone _._._._._. 11

Melania whiteavesi _.............. 47

Metallic mineral deposits _..... 63 sedimentary deposits of titaniferous iron ore -- $\quad 68$

veins bearing copper, silver, and gold -.....- 63

Metallic sillicon

Metallurgical flux _..._._._. 80,81

Mine, Herwood Rosetta - 63,64

Mineral resources _._. industrial-mineral resources _-. $\quad 69$ metallie-mineral deposits _....- 63

Mission Canyon Limestone, Madison
Group

Mississippian System _._. 12

Molar-tooth structure 9

Molding sand _..._. 80,81

Morrison Formation -

Mud-crack casts _..-_- 6, 7, 8, 9, 10, 27

Mud-flake brecela _.......... 7

Mytiloides mytiloides

\section{$\mathbf{N}$}

Oolite -

Ore $\ldots \ldots 6,65,67,68$ azurite bornite chalcocite --_-_-_-_-_-_-_-_ 64,65 chalcopyrite _... $64,65,66,67,68$

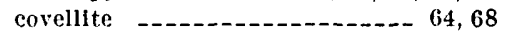

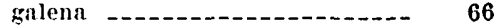
malachite -_._-_-_ $64,65,66,67,68$ pyrite -_-_-_-_-_-_-_ $64,65,66,67$ sphalerite _..._._. 66 tennantite -_-_-_-_-_. $64,66,68$ tenorite tetrahedrite

Ostrea -

anomiodes

sannionis _...

sp -

Oxytoma sp _... 28
Malletia sp - 29

Nuculana sp

Older colluvial deposits _._._. 54 
Page
25

$\begin{array}{ll}\text { Panope sy - } & 25 \\ \text { Patios } & \end{array}$

Pelecypods

$26,28,29,31,42$

Peronopsis

Petrified wood

Phelopteria linguaeformis sp

Phlycticrioceras oregonense

Pholodomya papyracea

Piers

-

Plant material, woody _..._.-. 18, 19, 20

Plantophyllum sp _._.

Plants _-

Portland cement -.._. 76

Pottery -.-_- 77

Precambrian basement rock inclusions

Precambrian rocks, Belt Supergroup Psetudoperna congesta

Punctospirifer $* p$

\section{Q}

Quartz latite

$38,40,49,51$

Quartz monzonite porphyry _-_ $58,60,61$

Quartzite, as construction stone -..

Quartzitic sandstone, as construction stone

Quaternary System

\section{$\mathbf{R}$}

Radiometric age determinations $-43,62,63$ Rallroad ballast _._._. $70,71,72,73,76$ Refractories _..._-_._-_._-_-_- 80

Refractory lining _..._._. 80,81

Reservoirs _._._._._. 79

Rhyodacite porphyry _._.

Rhyolite _......

Ripple marks _._-_ 6, 7, 8, 10, 15, 23, 27 Riprap _________ $70,71,72,74,75$

Road dressing _.............. 70

Koad metal _. 71

Road stone -

Roadfill _-

Rogers Mountain syncline -

Roofing granules -..-_-

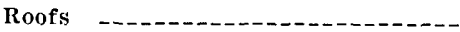

Rosetta mine

Rotary drilling mud

Rylstonia sp

S

St. Mary River Formation

Salt crestal casts

Sand, as industrial mineral resource

Siandblasting

Saurian bone fragment

Sawtooth Formation, Ellis Group -Scaphites binneyi

depressus

stantoni

impendicostatus
S

Scaphites - Continued Page

preventricosus _..........-. 26

tetonensis _... 26

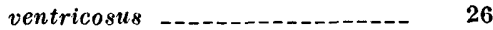

sp

Sciponoceras gracile _...-.....- 22

Sedimentary deposits, titaniferous iron ore - 68

Sedimentary member, western facies of Two Medicine

Formation - 30

Semiconductors - 80

Silica, as industrial mineral resource - 80,81

Silicon metal

Silicones -

Sills _.......

diorite -...- 59

latite -

quartz monzonite porphyry -.. 60,61

rhyodacite porphyry _..._- 59

rhyolite

trachybasalt _... 61

Sills, stone - 70

Siltite, as construction stone --..- 75

Sllver

Smelter flux _...

Snall

Spirifer rowleyi

sp

Spokane Formation, Belt Supergroup 7

Steps, stone _-_._. 70,72

Stoneware -

Stratified rocks _..... 5

Stromatolites _..._. 8

Sun River Canyon area _....... 23

Swallow Canyon syncline -

Sweetgrass arch _..._. 18, 24, 28, 42

Swift Formation, Ellis Group -..- 14

\section{$\mathbf{T}$}

Taft Hill Member, Blackleaf

Formation _... 18

Telegraph Creek Formation _..... 27

Tellina sp _. 29

Terrace facings _... 75

Terrace gravel _. 54

Terraces, stone

Terrazzo 70

Tertiary alkalic petrographic province -

Tile _... 77

Trachyanclesite:

flow. unit in Adel Mountain

Volcanics of Lyons

(1944) - 48,50

46 fragment: _........ $49,50,51$

6 Trachybasalt :

69 construction stone - 72

80, 81 flows. unit in Adel Mountain Volcanics of I,yons

(1944) _.

frigments _............ 49,51

intrusive

Trachyte:

construction stone _._. 71 
Trachyte-Continued flow, unit in volcunic member of Two Medicine Formation $32,33,38$

fragments

intrusive

30
$--\quad 40$

Traprock

Trilobites

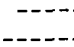

Turritella sp

Two Medicine Formation _......-

U

Upper course material, roads V

Vuughn Member, Blackleaf

Formation

Velns, metallic-mineral bearing divide between Little Creek and

Wolf Creek _..........

Gladstone Creek

Lanigan Mountain -...-..--.-

Iittle Creek and Sheep Creek -

Middle Fork of Little Creek ..-

Rosettil mine -.................

Wills Creek -

Vesicles _-

Viburnum montanum _... 52

Virgelle Sundstone -_._-_._- 28

Volcanic brecefa, unit in volcanic member of Two

Medicine Formation 33, 39, 40

unit in Adel Mountain Volcanics of Lyons (1944)
11,12

26, 27

30

Volviceram

Volcanic conglomerate, unit in

Page volcanic member of Two Medictne

Formation

unt in Adel Mountain Volcanics of Lyons (1944) _...--

51 Volcanic member, western facles of Two Medlcine

Formation

Wainscotting

W

Walls -.... 70,72

Watinoceras recsidei

19 Wearing course, roads -..- 71, 72, 75, 76

63 Welded tuff, devitrified _... $32,36,37$

frugments _..._. $34,38,39,40,41,48$

65 glassy _...

65 radiometric age determinations $4: 3$

66 sheets -

7 Western fucies, Two Medicine

Formation _...-..- 30

Willow Creek Formation

Wolsey Shale _._.

Woody plant material $\ldots$

Worm-burrow casts _..._._. 10, 15, 27

Worm tralls

$\mathbf{Y}$

48 Yellowstone National I'ark

37,54 